\title{
Cultivating Intelligent Consumption: The United States Food Administration and Food Control During World War I
}

James H. Smith

Follow this and additional works at: https://researchrepository.wvu.edu/etd

\section{Recommended Citation}

Smith, James H., "Cultivating Intelligent Consumption: The United States Food Administration and Food Control During World War I" (2015). Graduate Theses, Dissertations, and Problem Reports. 6672.

https://researchrepository.wvu.edu/etd/6672

This Dissertation is protected by copyright and/or related rights. It has been brought to you by the The Research Repository @ WVU with permission from the rights-holder(s). You are free to use this Dissertation in any way that is permitted by the copyright and related rights legislation that applies to your use. For other uses you must obtain permission from the rights-holder(s) directly, unless additional rights are indicated by a Creative Commons license in the record and/ or on the work itself. This Dissertation has been accepted for inclusion in WVU Graduate Theses, Dissertations, and Problem Reports collection by an authorized administrator of The Research Repository @ WVU.

For more information, please contact researchrepository@mail.wvu.edu. 


\title{
Cultivating Intelligent Consumption: The United States Food Administration and Food Control During World War I
}

\author{
James H. Smith
}

Dissertation submitted to the Eberly College of Arts and Sciences at West Virginia University

in partial fulfillment of the requirements for the degree of

Doctor of Philosophy in United States History

\author{
Elizabeth Fones-Wolf, Ph.D., Co-Chair \\ James Siekmeier, Ph.D., Co-Chair \\ Mark Tauger, Ph.D. \\ Melissa Bingmann, Ph.D. \\ David Hauser, Ph.D.
}

Department of History

Morgantown, West Virginia 2015

Keywords: food history, culture, nutrition, nutritionism, World War I, food control propaganda, Herbert Hoover, progressive era

Copyright 2015 James H. Smith 


\title{
ABSTRACT
}

\section{Cultivating Intelligent Consumption: The United States Food Administration and Food Control During World War I}

\author{
James H. Smith
}

This dissertation examines government food control in the United States during the First World War. More specifically, it looks at the food conservation program, and the associated propaganda, formulated by the United States Food Administration (USFA). The USFA was a wartime government agency headed by future president Herbert Hoover. I argue that the philosophy guiding the Food Administration's food control program was clearly influenced by a particular strain of progressivism that men like Hoover subscribed to. Using the input of experts in various fields such as nutrition, physiology, and advertising, the government was able to present a message to the American public that both generated an emotional response to act and educated people in a new, scientific approach to eating. Such an approach allowed Hoover to avoid imposing mandatory rationing, thus preserving the freedom from government intervention into the personal lives of American citizens. In addition to examining the various dimensions of Food Administration propaganda that attempted to stir the emotions and enlighten the intelligence of the people, this dissertation also examines a third theme that is found in the messaging. Hoover and his agency also worked to get Americans to think more about how their food choices might impact people and events overseas. Through their propaganda the Food Administration sought to get people to think more globally when considering the impact of their food choices. Though the Food Administration itself was relatively short-lived, the impact it had on the shaping of modern food culture was rather large. 


\title{
Cultivating Intelligent Consumption: The United States Food Administration and Food Control During World War I
}

\author{
Table of Contents
}

Introduction

Chapter 1

Food Dictator or Food Administrator?: The Creation of Government Wartime Food Control

Chapter 2

Awakening the War Consciousness of the American People

Chapter 3

Promoting "Individual Reconstruction" by Selling the Science of Eating

Chapter 4

Transitioning from a "War Consciousness" to a "World Consciousness"

Conclusion

Bibliography 


\section{Introduction:}

When the United States officially joined the Great War in April of 1917, the government moved quickly to initiate an unprecedented (and controversial) program to control the American food system. Never before had the federal government requested this level of power to determine what and how Americans would eat. To achieve this goal it formed the United States Food Administration. This wartime agency was tasked with a number of responsibilities, including the direct control of the domestic production and distribution of certain foodstuffs such as wheat, the prevention of hoarding and profiteering at the wholesale level, as well as the coordination of Allied purchases of American food supplies. In addition, the Food Administration was responsible for developing and administering a program that would attempt to control the amount and types of food the American public ate. The overall objective was to create a surplus of foodstuffs that could then be shipped to Europe in order to feed both the soldiers and the citizens of the Allied nations. In order to secure this cooperation, the government worked to craft a message for Americans to show them that the food conservation program not only provided them an opportunity to express their patriotism, but it also gave them a chance to practice new modes of efficiency within their homes.

Additionally, by cutting back on certain foodstuffs, Americans were led to believe that they were playing a crucial role in making their country an influential force among the world's major powers.

While certain government regulations were placed upon food producers, Americans' food consumption habits were to be altered through their voluntary cooperation with the United States government. This approach, as it related to individual 
conservation, reflected both an appreciation for long-standing American political tradition, as well as the modern progressive outlook of those individuals who were tapped to lead the Food Administration. This particular agency, along with the host of other wartime measures initiated by the government, represented a dramatic increase in the power and influence of the federal government. Such steps, especially in the midst of a war that was not universally supported by the public, had the potential of creating further internal unrest. A fundamental suspicion and fear of a powerful central governmental authority could be traced all the way back to the nation's origins. With the Food Administration in particular, the potential was there for federal power to reach all the way into the homes of American citizens. Herbert Hoover, the man that would come to lead the food control agency, appreciated such an outlook, and his particular approach to implementing government food control reflected a strain of progressive thought that envisioned a limited government role in addressing social crisis. While the Old World nations of Europe, the enemy Germany as well as our Allies, were forced to impose various degrees of rationing upon its citizens, American food conservation would be based on the voluntary cooperation of the people. In this scenario, the power of the government would be limited to providing expert guidance to educate the public on the reasons for and methods of food conservation. Once educated, the belief was that Americans would willingly comply with government conservation guidelines.

With this particular approach, it was believed that individual liberty would be preserved. Thus, in addition serving the explicit goal of increasing food shipments for people in need overseas, the success of this particular approach to food conservation would also serve as proof of the superiority of the American democratic political system 
over other, Old World systems. In addition, there were other, less explicit motives behind the particular nature of the American government's food control program. As stated previously, the nation's involvement in the First World War was not universally supported by the population. This reflected an overall tension that had existed in American society throughout the early twentieth century. It was during this period that the nation had experienced an enormous wave of immigration that contributed its overall ethnic and cultural diversity. America was increasingly transforming into a modern, urban country which led to a certain level of unease within mainstream American society. The Food Administration campaign was viewed by many as an opportunity to forge solidarity amongst the citizenry, not just to support the war effort, but to foster the creation of a more homogeneous society moving forward. In addition, those behind the wartime food conservation program saw it as an opportunity to convince the American public that the message of efficient, economical behavior could become a normal part of life after the conflict was over.

Thus, as suggested above, the U.S. Food Administration was in many ways a progressive project. Many scholars have studied the relationship between the progressive movement and World War I, examining both how the war impacted the movement and how progressive thought influenced wartime government policy. The Progressive Era was a period of American history that roughly encompassed the years 1890 to 1920 . Largely characterized as an attempt to deal with the drastic changes brought about by rapid industrialization, the period is marked with a myriad of complexities and contradictions that have perplexed and challenged scholars to this day. Was it a movement for social justice or was it an attempt at large-scale social 
coercion and control? Was "big business" the target of reform, or were they actually calling the shots? Who exactly were the progressives? Was there even a progressive movement at all? While historians continue to struggle with such questions, there is no doubt that American society at the turn of the twentieth century experienced long-lasting changes that were largely headed by an emerging group of reformers who had a faith in the power of government to exert its influence on society. ${ }^{1}$

Beginning in the nineteen sixties historians such as Robert Wiebe attempted to reformulate Richard Hofstadter's famous "status anxiety" interpretation. While he maintained the critical eye towards progressivism that had existed in Hofstadter's The Age of Reform, Wiebe disagreed with the idea that progressives were largely backwardlooking moralists driven by status anxiety. Rather, he argues that the era was created by a "new middle class" of professionals and social scientists who were determined to turn away from the past and establish order in a rapidly modernizing society. Wiebe relies heavily on social theory to explain the development of progressivism. Rapid industrialization at the turn of the century disrupted traditional social structures, threatening small, autonomous communities and resulting in social chaos, political corruption and economic instability. ${ }^{2}$

\footnotetext{
${ }^{1}$ Helen Veit, "Victory Over Ourselves: American Food and Progressivism in the Era of the Great War," PhD Dissertation, Yale University (2008), vii-xvii.

${ }^{2}$ Richard Hofstadter, Age of Reform: From Bryan to F.D.R. (New York: Vintage Books, 1955); One of the most prominent works to present this reinterpretation of Progressivism. Hofstader challenged the traditional scholarship that viewed Progressives as common Americans. Rather, he argued that the reform movement was urban in nature and was composed primarily of members of the traditional middle class who by the turn of the twentieth century were experiencing status anxiety. According to Hofstadter, ministers, lawyers and college professors, long seen as leaders of the community, were increasingly being overshadowed by the likes of political bosses and their allies in the business community. From this perspective, Hofstadter was able to take a more critical look at the movement and point out some of the more negative aspects of Progressivism. He saw the Progressive as moralistic and culturally intolerant middle class Protestants whose reforms were more about self-help than curing society's ills.
} 
A key belief that existed amongst this new, forward-looking group of reformers that included physicians, scientists and social workers was that government action was needed to impose order and stability on this increasingly urbanized society. Wiebe describes the fundamental transition that the U.S. government experiences during the early twentieth century, marked by an increased, direct involvement in society's operation and a newly powerful executive branch. He also makes key connections between the social thought of the new middle class and the era's broader intellectual changes. The new social reformers, with their faith in the power of government intervention, fit into the new intellectual trend that offered up a challenge to Social Darwinism. Wiebe's work is important in many ways, particularly because it was one of the first studies to fully describe the impulses that drove the new middle class to change society. ${ }^{3}$

While some scholars point to the beginning of U.S. involvement in World War I as the end point of the Progressive Era, it is hard to deny that progressive ideals continued to exert their influence. Indeed, some argue that World War I was in many ways the culmination of the era of reform. They often point to developments such as the passage of Prohibition and women's suffrage measures as evidence that the progressive spirit carried on after the U.S. joined in the fight. ${ }^{4}$ Entry into the war certainly divided the movement, but President Wilson was able to place U.S. involvement in progressive terms. The government quickly established bodies such as the War Industries Board

\footnotetext{
${ }^{3}$ Robert Wiebe, The Search for Order, 1877-1920 (New York: Macmillan, 1967); For a more recent overview of the Progressive Era, see Michael McGerr's A Fierce Discontent: The Rise and Fall of the Progressive Movement in America (New York: Simon and Schuster, 2003).

${ }^{4}$ McGerr, A Fierce Discontent; Ellis Hawley, The Great War and the Search for a Modern Order: A History of the American People and Their Institutions, 1917-1933 (New York: Waveland Press, 1997).
} 
and the Committee on Public Information to control production and rally public support. As a result, the war effort was organized along bureaucratic lines, and appeals for public cooperation were done so in the language of the Progressive Era: the war was part of a great moral crusade to reform the world and make it "safe for democracy." More recent works have examined the relationship between the war and progressivism in a broader, international context. Alan Dawley argues that, despite the diversity within the movement, progressives were driven by a hope that promoting their ideals at home would form the basis of an international campaign of social and moral reform. ${ }^{6}$

Scholarship on the work of the United States Food Administration during World War I had been relatively limited. Many studies of the American home front during the Great War managed to give a passing mention to the government's food control program, but most failed to provide an in-depth analysis of the Food Administration or explore its relationship with larger social, cultural and political forces. In recent years, however, this has begun to change. The structure of the Food Administration itself, where much of the agenda generated by the national offices in Washington was actually carried out at the state and community level, has given rise to a number of works that have examined the food control program in this localized context. Leslie DeBauche has shown that the government's food control agency and the burgeoning film industry forged a strong relationship during the war, while Celia Kingsbury examined Food Administration propaganda to show how the government's "campaign for scientific cooking" became part of a campaign linking food conservation with military victory. In

\section{Ibid.}

${ }^{6}$ Alan Dawley, Changing the World: American Progressives in War and Revolution (Princeton, NJ: Princeton University Press, 2003). 
terms of the Food Administration's links to progressive ideals, the recent work of

Elizabeth Cafer Du Plessis looked at how the "search for order" provided an idealogical basis for mobilizing food production and led to a greater emphasis on industrial agricultural practices. Helen Veit argues that the government's effort to change how American's ate was a progressive project and contributed to a lasting American obsession with food and science. ${ }^{7}$

By focusing in on the propaganda campaign developed and implemented by the U.S. Food Administration, this project will attempt to answer two major questions. First, how did the United States government work to control the food behavior of its citizens during World War I? Second, how did the progressive movement inform the message presented to the American people by the U.S. Food Administration? Like the work of Du Plessis and Veit, the goal of this study is to show that in many ways the Food Administration represented a continuation of Progressive Era ideals, in which an active central government, guided by emerging middle class experts and professionals, had a greater role in American society. Further, this study will show how the wartime food control program, with its reliance on nutritional science to shape policy and use of modern advertising and publicity techniques to shape public attitudes played a key role in the development of modern food behaviors. Today, many Americans place a great

\footnotetext{
${ }^{7}$ Celia Malone Kingsbury, For Home and Country: World War I Propaganda on the Home Front (Lincoln, NE: University of Nebraska Press, 2010): 32; for examples of studies of the Food Administration at the local or state level, see Rae Katherine Eighmey's Food Will Win the War: Minnesota Crops, Cooks, and Conservation During World War I, (St. Paul, MN: MHS, 2010), Angela Jill Cooley's "Hearth, Home, and Hoover: The Politics of Food in Alabama, 1896-1919," The Southern Historian, vol. 27, (2006), 38-58, Erika Janik, "Food Will Win the War: Food Conservation in World War I Wisconsin," The Wisconsin Magazine of History, vol. 93, no. 3 (2010), 17-27, or Joseph Carruth, "World War I Propaganda and Its Effects in Arkansas," The Arkansas Historical Quarterly, vol. LVI, no. 4 (2007) 385-398; Leslie M. De Bauche, Reel Patriotism: The Movies and World War I (Madison, WI: University of Wisconsin Press, 1997); Veit, "Victory Over Ourselves."
} 
deal of emphasis on the nutritional composition of foods in assessing its value. This phenomenon, referred to as "nutritionism" by many food experts, can trace its origins back to the early twentieth century and in particular the work done by the U.S. Food Administration.

This study will attempt to distinguish itself from recent scholarship by focusing on government propaganda and the message it was trying to convey to the American public regarding the food choices it made during the war. Whereas Du Plessis focuses primarily on the impact of "progressive science" and government food control on the agricultural industry and food production, my study will focus on the opposite end of the food chain: consumption. In addition, this project is different from Helen Veit's recent work in terms of how it assesses the specific importance of the U.S. Food Administration. Veit's study focuses much of her attention on the progressive influence on American food culture that preceded the war by many years. According to her, by the time the government created the Food Administration, the public welcomed the opportunity to participate in conservation efforts. Here, the wartime government of Woodrow Wilson will play a more central role, as one of the major themes I will be exploring is they ways in which the USFA used propaganda to address public resistance to this unprecedented government action. In utilizing the services of leading experts in emerging fields of science, nutrition, public policy and advertising, the government actively sought to promote a particular type of food consumption by presenting a carefully crafted message via a number of outlets. This work presents and examines three distinct themes within the government food control propaganda. First, the Food Administration contained messages and imagery that presented a strong emotional 
appeal to the American public. With the purpose of arousing the "war conscious" of the population, much of propaganda contained militaristic and patriotic language to drive home the idea that each and every food choice being made at home would have an impact on the outcome of the war being fought overseas. The second aspect of Food Administration propaganda was to explain the "hows" and "whys" of food conservation by educating the American public in the ways of scientific eating based on the principles of the emerging field of nutrition. Finally, an important aspect of the government conservation program emphasized the global dimensions of the wartime food crisis. Americans were bombarded with propaganda that drove home the idea that their nation was part of a global community and poised to take a leadership role once the war was over. The goal of this project is to help provide a better understanding of the political, social and cultural forces that helped alter Americans' relationship both with their government and their dinner plate.

The Food Administration was headed by Herbert Hoover, the engineer and future president who by 1917 had risen to international fame with his relief work in war-torn Belgium. The agency was headquartered in Washington, D.C. and had representatives stationed in each of the Allied nations. Each state also had an office, which worked closely with the leadership in Washington. The officers of the agency were primarily volunteers, and most were recognized for their professional expertise in a particular field, including social scientists, nutritionists, home economists and advertising executives. The operation they directed was well-organized and productive, a model of progressive efficiency. 
This project analyzes the various ways in which the government, through the United States Food Administration, attempted to influence American food behavior during World War I. More specifically, it explores the propaganda produced by the U.S. Food Administration during the First World War. In being committed to the avoidance of a compulsory rationing program, the government had to convince Americans to voluntarily conserve food and thus had sell the public on the apparent benefits of following Food Administration guidelines. The government attempted to reach Americans through a number of different mediums. Experts in the fields of nutrition and various social sciences advised Americans through the printed page and the spoken voice. The Food Administration coordinated the publication of articles in both popular and professional periodicals, and sponsored various public lectures. In addition, the government worked closely with the film industry to convey its message on food control to the masses. It also attempted to educate the public through direct interaction with its activities at a number of state fairs and festivals. The Food Administration also worked to target specific groups with its propaganda. It produced textbooks and other materials for college courses and created divisions within its structure to deal solely with African Americans and working class groups.

The first chapter of this work examines the events surrounding the creation of the U.S. Food Administration. The issue of a government-directed food control program was a hotly-debated topic in the spring and summer of 1917 and reflected the tensions surrounding both U.S. involvement in the war, as well as the growing concerns of a food crisis at home. This chapter examines the political debate leading up to the passage of the bill that created the Food Administration looks at the nature of the political resistance 
to the Lever Food Control Bill, as well as the growing social tensions over rising food prices. It also examines how the Wilson administration attempted to shape the nature of the debate and appeal directly to the public to convince them that such legislation was necessary. Finally, the chapter introduces a number of the major figures within the agency and provides some insight into their backgrounds in an attempt to associate them with the progressive movement.

Chapter two begins the in-depth examination of Food Administration propaganda. Specifically, it looks at the aspects of the agency's message that was aimed at eliciting an emotional response from its audience. It shows how the Food Administration utilized the expertise of the burgeoning modern advertising industry to sell the food conservation campaign to the American people. To accomplish this goal the government utilized nearly every conceivable medium, including a motion picture industry still in its infancy. In addition, the government produced numerous examples of printed materials, including posters that were put on display throughout the nation. Finally, this chapter examines a particularly intimate aspect of the Food Administration, the home card campaign which placed the government directly inside the home of Americans.

The third chapter focuses on aspects of food conservation propaganda that sought to educate the American people on the specific actions that had to be taken in order to comply with government guidelines. Utilizing the input and guidance of various experts in the fields of biological and nutritional sciences, the Food Administration generated propaganda that aimed to shape American food behaviors that took a more scientific or rational approach to eating. Particular attention is given to efforts made by the government to reach and educate Americans attending state and county fairs, as 
well as children attending schools at all levels. Chapter four looks at the transnational dimensions of Food Administration propaganda. Working closely with its counterparts in Britain and France, the U.S. government attempted to connect food conservation and substitution at home with the broader global struggle against German aggression. Not only did the Food Administration work closely with Allied food controllers and media outlets to portray the food situation in England, France and Italy as being extremely perilous, it also made sure the American public knew that the fruits of their sacrifice were going to a worthy recipient that was conscious and appreciative of American efforts. Rather than being a burden, the program created by the Food Administration offered the nation an opportunity display its strength and efficiency to the rest of the world.

The U.S. Food Administration not only succeeded in convincing the majority of Americans that they needed to at least consider the impact their dietary choices might have on the immediate outcome of the First World War, it was perhaps the first time the American public on such a broad and comprehensive scale was presented with a new way to approach the subject of food itself. In many ways, the effects on modern American food culture are still behind felt today. 


\section{Chapter 1 - "Food Dictator or Food Administrator?: The Creation of Government Wartime Food Control"}

On April 6, 1917, the United States declared war on Germany. By that time the Great War had been raging for nearly three years, with the Entente Powers led by France and Britain battling the Central Powers led by Germany and Austria-Hungary. From the start, both the American public and its political leadership had proclaimed a strong desire to remain out of the military conflict. Woodrow Wilson's reelection campaign of 1916 used the slogan "He Kept Us Out of War" to win another presidential term. However, while the U.S. government maintained its neutrality and avoided sending troops into the fray, American money and supplies were increasingly being shipped across the Atlantic to aid the French and the British. The Germans, who had implemented a blockade to prevent such actions, initiated submarine warfare against ships coming from the United States, which resulted in a number of incidents where German u-boats sunk American ships, as well as the British passenger ship the Lusitania. Over time, as the number of attacks increased, more and more Americans, including the president himself, abandoned their neutral stance and began pushing for full-scale military involvement. In March of 1917, the U.S. intercepted the "Zimmerman telegram" and was quickly published in newspapers. The German note proposed to Mexico a joint attack against the United States. This was the final straw, and within a few weeks President Wilson was standing before Congress to request a declaration of war. ${ }^{1}$

\footnotetext{
${ }^{1}$ David Kennedy, The First World War and American Society (New York: Oxford University Press, 2004) $10-44$.
} 
Soon after war was declared, President Wilson called upon Congress to give him certain powers to control the production, distribution and consumption of food in America. The next day, the Council of National Defense--an advisory body created by Wilson the previous August for the purposes of planning for the mobilization of the American home front in the event of war--contacted Herbert Hoover to request that he head up its committee on dealing with the supply of foodstuffs. Hoover, a mining engineer from lowa who was living in London at the time, was already a relatively wellknown figure both at home and abroad. He had achieved international acclaim for his humanitarian work as head of the Commission for Relief in Belgium. His experience in handling the administration of food relief on such a large scale made him a natural choice to tackle the issue of wartime food control back in his home country. ${ }^{2}$

However, the process of constructing the institutional machinery that would allow the president to carry out his objectives would prove quite difficult. Much of the justification for implementing a food conservation program at home was based on the argument that America's allies overseas were facing a food crisis. However, Americans themselves were facing a food crisis of their own. Rising prices and shortages had already led to a series of food riots in some of the nation's largest cities. Americans would be hesitant to cut back when they were already struggling to fill their pantries. Still, the power requested by the president over the nation's food supply was in many ways unprecedented. Thus, the White House also faced resistance from those who feared such a government agency would put too much authority in the hands of one

\footnotetext{
2 George H. Nash, The Life of Herbert Hoover: Master of Emergencies, 1917-1918 (New York: W.W. Norton, 1996), 3-6.; David M. Kennedy, Over Here: The First World War and American Society (New York: Oxford University Press, 2004), 114-117.
} 
person. The result was a heated political struggle and public debate over right of the government to have control over the basic of human resources, food.

This chapter examines this debate and provides insight into the arguments for and against legislation that authorized the government to exert control over the nation's food system. It will attempt to show that, for the most part, the confrontation over wartime food control was part of a larger conversation about what role, if any, government should play in the lives of its people. While those opposed to such a measure viewed it as a threat to the basic freedoms of the American people, advocates like Herbert Hoover saw it as an opportunity to reaffirm, on a global scale, the superiority of American democracy. It also provided an opportunity for progressives to use the power of the state and the knowledge of experts to solve various social problems such as the one surrounding food. The outcome of this struggle showed that, for the most part, the American people were willing to put old fears to rest and follow the lead of administrative experts like Hoover in the implementation of this ambitious government initiative.

Most historians of the Progressive Era have agreed that World War I had a dramatic impact on the reform movement. However, while some have argued that the war signaled the end of the era, others, like Michael McGerr have suggested that the war actually strengthened progressivism. In looking at the war itself, historians have come to a number of different conclusions as to the event's impact on American society. One of the earliest and most notable works published within the past thirty years comes from Ellis Hawley's The Great War and the Search for a Modern Order: A History of the American People and Their Institutions. In this work, Hawley offers new insight into the 
war period to show that it was a precursor of the America that would emerge in the years following World War II. According to him, the years from 1917 to 1933 saw a "quest by men deeply influenced by the organizational experience of a democracy at war to draw from that experience a set of liberal ordering mechanisms capable of coordinating an expanding organizational economy and fostering peaceful progress." Not only did this experience lead to an attempt to balance laissez-faire with overbearing statism on the domestic side, it lead to an attempt to balance isolationism with internationalism in the international sphere. Not only does the story of the Food Administration reflect the tensions between direct state intervention and concern for a central government with too much power, it also expressed a the desire held by many progressives for the United States to become more active in global affairs both during and after the conflict. ${ }^{3}$

Ronald Schaffer argues that World War I caused a social and political revolution in America in which a wartime welfare state was created with pervasive federal government control. Looking at a number of different contexts, from the farm to the battlefield, Schaffer develops two major themes. One deals with the government's management of the war, while the other deals with Americans' use of the conflict to advance their own personal agendas. He looks at the work of councils of defense, which were created by state and local governments and used their powers to intimidate citizens and silence dissent. He also discusses the way in which the war produced a welfare state for business, in which large companies were able to obtain huge

\footnotetext{
${ }^{3}$ see Michael McGerr's A Fierce Discontent: The Rise and Fall of the Progressive Movement in America, 1870-1920, (New York: Oxford University Press, 2005); Ellis Hawley, The Great War and the Search for a Modern Order: A History of the American People and Their Institutions, (New York: St. Martin's Press, 1992), 8-15.
} 
government contracts while eliminating competition. In many ways, what Schaffer describes is a continuation of progressive desires to create a more uniform, efficient society. In addition to describing the war as a climax of the progressive movement, Schaffer finds that much of the revolutionary changes lasted well beyond the end of hostilities and could be seen in the policies that shaped both the New Deal and the society during the Second World War. Alan Dawley has also examined the war's broader impact on American society. He describes a conflict caused by the contradictions of the liberal state and the strains of American involvement in world politics through the mid-1920s. Domestically, such contradictions can be seen in a reform movement committed to addressing inequality within an economic system that caused such disparities. From an international standpoint, the conflict arose from a nation with a long-standing anti-imperialist tradition coming to grips with its new role as a global power. However, Dawley sees the attempt to reform American government by middle- and working-class Americans as short-lived. According to him, the immediate postwar period saw a return by ruling elites to laissez-faire economics and social repression. 4

With the vision and leadership of Herbert Hoover, the U.S. Food Administration's food conservation campaign reflected a particular brand of progressivism, one in which the heavy hand of the state was avoided in favor of a government program shaped by experts that relied on the voluntary cooperation of the public. Joan Hoff Wilson was one of the first scholars to place Hoover and his career as both a private and public figure

\footnotetext{
${ }^{4}$ See Ronald Schaffer's America in the Great War: The Rise of the Welfare State (New York: Oxford University Press, 1991); and Alan Dawley's Struggle for Justice: Social Responsibility and the Liberal State, (New York: Belknap, 2000) and Changing the World: American Progressives in War and Revolution, (Princeton, NJ: Princeton University Press, 2003).
} 
within the context of the progressive movement. From his earliest days as a child of a Quaker family in rural lowa, to his coming of age in California as a student at Stanford University, to his experiences as a successful mining engineer, Hoover developed the belief that a country populated with intelligent citizens committed to a philosophy of "cooperative individualism," and guided by a corporate state, would allow the United States to emerge as a powerful, modern nation. Such an arrangement, in Hoover's eyes, would allow decisions made by the federal government to be executed in a decentralized fashion, while also allowing the nation to preserve some of its best traditional values, such as individual liberty. According to Hoff-Wilson, the outbreak of the First World War accelerated the formulation of Hoover's progressive political views, and his experience as the head of the Food Administration affirmed the efficacy of two methods that could be used to maintain a balance between the extremes of state socialism and monopoly capitalism. First, was the use of publicity to mold public philosophy, and the second was the utilization of voluntary decentralized groups to carry out nationally-coordinated programs. These methods would serve as the basis for the government's program to promote food conservation amongst the American population. 5

Even before the United States had officially entered the Great War, Hoover had expressed to the Council of National Defense his concerns about a coming food crisis in Europe and suggested how America might factor into a relief program in the event it joined the war. His words provided keen insight into the ideas and attitudes that would

\footnotetext{
5 Joan Hoff-Wilson, Herbert Hoover: Forgotten Progressive, (Boston: Little Brown, 1975), 3-78; Robert D. Cuff, "Herbert Hoover, The Ideology of Voluntarism and War Organization During the Great War," The Journal of American History 64 (September, 1977): 358-372; for a first-hand perspective on Hoover's philosophies see American Individualism, (New York: Doubleday, Page \& Co., 1922); for an expansive and detailed overview of Hoover's wartime experience as a public servant, see George H. Nash's The Life of Herbert Hoover, Master of Emergencies, 1917-1918, (New York: W.W. Norton, 1996).
} 
guide both the formation and nature of wartime government food control in the United States. While a wartime emergency had created the need for active government control of both the production and consumption of food, a prevailing faith in the unique democratic nature of American society led experts like Hoover to advocate that such a program would be distinguished from its European counterparts. For while supporters of food control found it impossible to achieve the goal of feeding the Allies without suppressing consumption, the method of such supression would be "indirect." Thus, while the governments of Germany and Belgium were relying on strict rationing programs to conserve food supplies, the conservation of food in the United States would rely on the voluntary cooperation of its citizens. ${ }^{6}$

Hoover gladly heeded his nation's call and quickly began gathering data on the food situations facing the Allies. For three weeks he consulted with officials from Britain, France, and Italy. What he found was troubling. A combination of poor harvests, a diversion of agricultural manpower and a disruption of normal trade networks had put the nations of England, France and Italy on the verge of famine. Food supplies would not last beyond September if imports from the United States were not dramatically increased. By the end of April--before he even arrived on American shores--Hoover, then labeled as head of the "American Food Board" was explaining to the American public what was to be expected of them. He asserted that Americans needed to engage

\footnotetext{
${ }^{6}$ The Council of National Defense was created by the Wilson Administration in the summer of 1916 . It was an advisory organization that was to create a national plan of war preparedness, focusing primarily on coordination of resources and industry, in the event the nation became involved in the conflict. see Kennedy, Over Here, p 116-117; Herbert Hoover, "Notes on National Food Control (Jan, Feb, Mar)," undated, United States Food Administration Records, Box 1, Folder 2, Hoover Institution Archives, Stanford University.
} 
in "rigorous self-sacrifice" to reduce their consumption of food by "economizing" and eliminating waste. For Hoover, the stakes could not be higher. ${ }^{7}$

In addition to the immediate needs of a wartime emergency, food control for expert administrators like Hoover had broad implications, not only for American society, but for the rest of the world. Looking simply beyond the war's outcome, Hoover argued that the future stability of western nations hinged on achieving the goal of reducing food consumption. Failure to solve this problem, he warned, "may possibly result in the collapse of everything we hold dear in civilization." For the U.S. specifically, there were economic and moral advantages for such a program, and the two were closely linked. He emphasized the "importance of reducing extravagance and waste" to prevent the overall costs of war from causing deeper problems for the American economy. "Furthermore," claimed Hoover, "the moral advantage of a disciplined people in preparation for after-war competition is of great importance." Thus, by making their kitchens less wasteful and more efficient, American citizens would not only be helping its nation achieve victory in war, they would also be helping the U.S. position itself as a legitimate power in the postwar global landscape. ${ }^{8}$

Hoover arrived in the United States at the beginning of May and quickly established a headquarters at the New Willard Hotel in the nation's capital. On May 19th, both President Wilson and Hoover issued statements outlining in detail the executive branch's plan for food control. The president also presented his reasons for

\footnotetext{
7 Nash, The Life of Herbert Hoover, 5.; "Economize of Food, Warning by Hoover," New York Times, April 22, 1917

8 "Economize of Food, Warning by Hoover," New York Times, April 22, 1917; Herbert Hoover, "Notes on National Food Control (Jan, Feb, Mar)," undated, United States Food Administration Records, Box 1, Folder 2, Hoover Institution Archives, Stanford University.
} 
requesting such unprecedented powers to regulate the nation's food system. The statements reflected a strong belief in the ability of a democratic society, composed of an informed public and led by expert government administrators, to overcome obstacles with as little disruption and inconvenience as possible. This was a prime example of progressive thought put in action. In general, the powers were to be used in order to prevent misunderstandings and assure cooperation from all aspects of the food chain, from farmer to consumer. With these powers, the president sought the ability, through the U.S. Food Administration, to do such things as prevent speculation, control prices, prohibit wasteful use of foods, and, only if necessary, take direct control of certain aspects of the system. In this way, governmental authority could be focused and used sparingly, reserved only for the "small and selfish minority" that refused to "put the Nation's interests above personal advantage."9

Hoover also stressed that such powers needed to be granted to the president by Congress so that a competent administration could be established. For him, there were two general aspects to competent war administration: a centralized and single responsibility (in this case, food control) followed by a delegation of this responsibility to a number of decentralized administrative organs. In explaining his vision for wartime government food control, Hoover presented his particular take on progressive reform. He laid out what he called the "five cardinal principles of food administration," which reflected the view that the food problems facing America could be solved with a limited government response. He stressed that the solution rested on the effective coordination

\footnotetext{
9 "Chronological Sketch With Directory of Members, May 1917-June1919," March, 1920, United States Food Administration Records, Box 1, Folder 2, Hoover Institution Archives, Stanford University; "President Wilson Asks Mr. Herbert Hoover to Undertake Task of Food Administration," New York Times, May 20, 1917.
} 
of existing institutions and the unified cooperation of a willing public. First, Hoover discouraged the use of terms like "food dictator" or "food controller" to describe his role. Only "food administrator" accurately reflected his position. He made it clear that personal gain was not a driving force behind him getting involved. "My ambition," he claimed, "is to see my own people solve their own problem." Second, he asserted that most of the goals of the Food Administration could be accomplished using existing agencies. The third cardinal principle according to Hoover was community-based food conservation. Fourth, that most of the "important positions" of the Food Administration be filled with volunteers. The final principle was the need for the agency to be independent and under the direct control of the president, while also cooperating with other departments like Agriculture and Commerce. ${ }^{10}$

In describing the organizational structure of the agency itself, Hoover envisioned that the U.S. Food Administration would be divided into four branches: one to oversee and regulate the production and distribution of a few "critical commodities," another that would coordinate the cooperation with food administrations at the local and state level, a third that would oversee cooperation with Allied nations and a fourth branch that would serve as a department of "domestic economy." It was this with department that the government would interact directly with the American consumer. While Hoover made it clear that he hoped his work would result in the overall reduction in the consumption of food in the United States, he tried to assure the public that the government would not force Americans to go hungry. Waste and extravagance were the main targets, while practices such as substitution and buying locally would be stressed over outright 
deprivation. "We do not ask that the American people should starve themselves," said Hoover, "but that they should eat plenty, wisely, and without waste."11

One aspect of the Food Administration that both Wilson and Hoover stressed in their initial public comments on the subject of food conservation was the temporary nature of the agency. Government food control was clearly characterized as an emergency war measure, and Americans did not have to worry about continued intrusion into their eating habits once the hostilities ended. "All control of consumption," assured the president, "will disappear when the emergency has passed." To further bolster this claim, Wilson pointed out that the staff of the Food Administration would serve on a volunteer basis, without financial compensation of any kind. "There need be no fear," said the president, "of the possibility of a permanent bureaucracy arising out of it."12

Such assurances not only reflected a concern of a permanent and intrusive expansion of federal power, it also reflected a providing faith among progressives like Wilson and Hoover in the ability (and willingness) of members of a democratic society to sacrifice in times of emergency. The culture of voluntarism surrounding the U.S. Food Administration was something that was heavily stressed. "I believe that the whole foundation of democracy," claimed Hoover, "lies in the individual initiative of its people and their willingness to serve the interests of the Nation...in this time of emergency." Hoover actually made it a condition of his acceptance of the position of head of the U.S. Food Administration that he and his assistants receive no compensation. In Hoover's

\footnotetext{
11 “Hoover Suggests Nation's Motto: 'Eat Plenty, Wisely, Without Waste,"' New York Times, May 20, 1917. 12 "President Wilson Asks Mr. Herbert Hoover to Undertake Task of Food Administration," New York Times, May 20, 1917.
} 
mind, what was being asked of him and what he was going to be asking private citizens to do in their kitchens was no different than what was being asked of men that were risking their lives overseas. "Those who can not serve in the trenches," he said "can show their patriotism in no way so fully as in this service, and I feel that we have as much right to call upon them to serve...as we have a right to call upon our men to serve in the trenches." All that was needed to receive the cooperation of the public was an information campaign that would educate the American people and show them what was needed. According to Hoover, Americans would gladly sacrifice "if they understood the need and were satisfied with the soundness of the methods proposed to accomplish the results."13

The challenge of food conservation and the solution proposed by the Wilson administration was also placed within the broader ideological context of the war itself: democracy vs. autocracy. The food emergency provided a test for the nation's people and its democratic institutions, and in Hoover's opinion a positive response to his program would prove to the entire world the legitimacy of the American way of life. For while the citizens of European nations like Germany faced starvation despite living under strict rationing programs, the U.S. Food Administration's program could show that, under a democracy, people could sacrifice and save on their own terms and conserve while still living comfortably. For Hoover, cutting back on wasteful food consumption meant more than merely winning the war:

\footnotetext{
13 "Hoover Suggests Nation's Motto: ‘Eat Plenty, Wisely, Without Waste,"” New York Times, May 20, 1917; William C. Mullendore, History of the United States Food Administration, 1917-1919 (Palo Alto, CA: Stanford University Press, 1941), v, 65-68. While Mullendore's history was not published until 1941, the text of the work was prepared immediately after the end of the Great War and completed in 1921. There appeared to be no intention of publication, but in 1941, with the world once again at war, there was yet another global food problem, giving the story of the U.S. Food Administration "special significance."
} 
I hold that democracy can yield to discipline and that we can solve this food problem....and that to have done so will have been a greater service than our immediate objectives, for we have demonstrated the rightness of our faith and our ability to defend ourselves without being Prussianized.

If conservation could not be achieved through the voluntary cooperation of the American people, the very worth of democracy would be called into question. If the nation could not heed the call of food conservation, "it is better to accept German domination," asserted Hoover, "and confess the failure of our political belief."14

Despite the unwavering faith in the nation's ability and willingness to sacrifice in the name of democracy and self-defense, Hoover faced a number of obstacles as he formulated this plan of food control, the most important being the scarcity and high price of food. If food prices rose to the point of causing widespread unrest, the ability of the nation to conserve and fulfill demand would be greatly compromised. Much in the same way an industrial workers' strike could threaten to bring war production to a grinding halt, nationwide food riots could halt American food exports and push our European Allies closer to the brink of famine. Social disruption had to be avoided at all costs if the nation's kitchens were to be converted to maximum efficiency. ${ }^{15}$

There were a number of forces conspiring to put pressure on the American food system by the spring of 1917 . An increase in demand came not only from the military forces being assembled at home, but also from our overseas allies. War conditions had

\footnotetext{
14 "Hoover Suggests Nation's Motto: ‘Eat Plenty, Wisely, Without Waste,"' New York Times, May 20, 1917; "Regulation, Not Confiscation, Sought," The Evening Journal (Richmond, VA), June 21, 1917, clipping from Records of the U.S. Food Administration, Record Group \#4, 12HA-A10, Box 489, National Archives.

${ }^{15}$ Mullendore, History of the United States Food Administration, 48-51.
} 
cut the domestic production of food in places like Britain and France, while the revolutionary events in Russia and the German U-boat attacks had cut off access to key external supplies of foodstuffs. The situation was made worse by that fact that poor growing conditions in the agricultural regions of the U.S. in 1916 and 1917 had reduced the available supply of key crops. ${ }^{16}$

However, by the time Hoover arrived in the nation's capital to begin putting the pieces of his administration in place the rising cost of food was already a major concern for many around the country. In fact, a small wave of food riots had already broken out a few months earlier in a few major northeastern cities. On February 19, the working class districts of Williamsburg and Brownsville in Brooklyn, New York erupted as a group of women shoppers attacked peddlers at markets, overturning and setting fire to their carts. The women rioters, whose number approached three thousand according to news estimates, were protesting food prices. A similar episode occurred three days later in the working class neighborhoods of Philadelphia, where a mob of women fought with retailers upon hearing news of dramatic price increases for items such as fish and onions. The women claimed robbery and responded by pouring kerosene on the merchandise. In both cases the police was called in to quell the unrest, and a number of the protesters were arrested. ${ }^{17}$

A few days after the riots in Brooklyn, the New York Times sent a reporter into the Lower East Side of Manhattan to report on conditions facing working class families as it

\footnotetext{
${ }^{16}$ Robert Zieger, America's Great War: World War I and the American Experience (Lanham, MD: Rowman \& Littlefield, 2000), 72-73.

17 "Pushcarts Burned in Riots Over Food," New York Times, February 20, 1917; "Riots in Philadelphia," New York Times, February 23, 1917.
} 
related to food prices. While there was no evidence of widespread starvation, it was clear that the advancing cost of food had put added pressure on the already limited resources of thousands of working families. The result was widespread suffering that created anger and resentment towards vendors whom they saw as conspiring against them. A few women who admitted to participating in demonstrations shared their experiences. Two were self-described as "better off" than the majority of the neighborhood residents--one was a housewife whose husband was a watchmaker and the other was a forewoman at a local factory--yet their stories displayed how food prices contributed to their suffering. With a food budget of $\$ 1.25$ per day, one of the women said that current prices made it difficult for her to feed her entire family. The other had kept detailed records of price increases. Eight months prior two pounds of onions cost $\$ 0.06$, while four pounds of potatoes cost $\$ 0.08$. Customers were now paying five times that amount for the same products, and despite the higher prices, the quality of the food had declined. ${ }^{18}$

In response to the unrest, a number of actions were taken at different levels to not only find a cause, but to work towards a solution. On the evening of the New York riots, a group of peddlers called a mass meeting at New Plaza Hall in Brooklyn. The meeting was primarily an attempt for the peddlers to get out their side of the story and answer the charge that they were the cause of high prices. Hours before the eight o'clock meeting the hall was filled to capacity and a crowd of fifteen hundred gathered in the streets outside. During the meeting the peddlers asserted that they were not to blame. They were paying equally inflated prices to wholesalers, with one vendor

18 "Market Tour Shows East Side is Pinched," New York Times, February 23, 1917. 
asserting that he had struggled to make a paltry seventy-five cent profit the previous week. To further bolster their claim that vendors and consumers were in the same boat, a committee of five was appointed to speak directly with the New York mayor and appeal for "drastic action" to control prices. ${ }^{19}$

Another meeting, this one organized as a general protest against food prices in the city, was held the next day at Forward Hall in the Lower East Side. With a crowd of over five thousand attempting to fill the space, the atmosphere reflected the emotional nature of food prices for the working class. According to reports, the gathering was on the verge losing control and was "one of the wildest seen in New York in many years." Gates that had been placed outside to hold off the overflow eventually gave in and a rush from outside poured in. There were reports of children being trampled and clothing being torn, while shouts from the crowd denounced capitalism as the major reason why the working class was struggling to buy food in the "greatest, richest city in the world." Order was restored at the gathering long enough for the attendees to adopt a plan of action, which included a demonstration on Wall Street and the appointment of a delegation to demand that the city government appropriate $\$ 1$ million to purchase food for distribution at cost. In late February in Manhattan the Mothers' League called a mass-meeting in Madison Square to protest the price of food. Once again, the marchers were primarily of the immigrant working class, and all expressed their anger and frustrations at not being able to feed their families on the wages they were earning. At one point the protestors decided to march on the Waldorf Astoria hotel to take their concerns directly to the governor. However, they were greeted with barricades, and after

19 "Pushcarts Burned in Riots Over Food," New York Times, February 20, 1917. 
the crowd grew more restless, the police was called in to break up the gathering by force. 20

The events in New York and Philadelphia became a national issue, and the riots were discussed and debated on the floors of both houses of Congress. Congressman William Borland of Missouri called the riots a disgrace and demands were made to give the Federal Trade Commission the power to investigate the nation's food situation and the alleged manipulation of prices. One important distinction of the current situation according to the likes of Borland was the type of people who were suffering. "These are not the wives of idlers who are now complaining of the lack of bread," asserted the Congressman. Rather, it was the deserving poor, those working and not depending on handouts, that was struggling to put food on the table. The New York Times expressed a similar sentiment. Describing what it called "a demonstration of hunger for the poorest amid plenty for most," the Times argued that the loudest cries were not coming from the unemployed, but from workers who earned. They merely possessed an "inability to buy what the accustomed wage ordinarily supplies."21

One theory of a possible cause of the unrest that was circulating and that the Times acknowledged was a plot by German officials and sympathizers to promote discontent and class warfare within American society. Claims were made that the leaders of the recent food riots had received payments from the German government to ignite the unrest. The federal government actually launched an investigation to examine

\footnotetext{
20 "Women in Uproar at a Food Meeting," New York Times, February 21, 1917; "The Food Demonstrations in New York, Special Correspondence," The Outlook, March 7, 1917, 405-406.

21 "House and Senate Debate Food Riots," New York Times, February 22, 1917; "The Food Demonstrations," New York Times, February 22, 1917.
} 
such claims, but found no evidence that the accusations had any basis in fact. A more valid cause for the rising prices according to the Times was an ever-increasing demand for American foodstuffs from abroad. Since this demand showed no sign of slowing down, the editorial suggested that a reduction in wasteful consumption be practiced among those that could afford to do so. "Wasters of every degree are the worst enemies of the poor," claimed the Times. It advised that individuals that had the capacity to purchase freely should "take advantage of the many opportunities to economize."22

As it became clearer that the cause of rising prices was at least in part due to demand overseas, those struggling to purchase food began calling for government action that would solve the problem. While the general consensus was that the wartime conditions required the relatively drastic measure of government food control, some media outlets called for a long-term system of food administration. While entities like the New York Times urged the wealthy to economize, groups like "Feed America First" called on the federal government to place an embargo on food shipments to European countries. In the wake of the New York food riots "Feed America First" held a meeting in St. Louis and urged nationwide demonstrations to spur government action. The leader of the St. Louis meeting predicted revolution in America if the government failed to take action to control food prices. While episodes in the nation's largest cities were receiving the most attention, the rising cost of food was a problem that was affecting people, especially the working class, in all parts of the country. Increasingly, social commentators as well as political leaders were drawing parallels between the current

22 "The Food Demonstrations," New York Times, February 22, 1917; "No Plot in Food Riots," New York Times, February 24, 1917. 
conditions facing the United States and the "bread riots" that had immediately preceded the revolution in France at the end of the eighteenth century. ${ }^{23}$

While the federal government failed to heed the calls for an embargo on food exports and failed to take any action beyond floor debate, a number of local and city government made attempts to alleviate the suffering caused by high prices. In the days following the Philadelphia food riots, butchers in the city vowed to stop selling meat until prices were reduced, and a group of the women declared a "school strike," in which they kept their kids home from school because they were too weak to study and attend classes due to a lack of food. In response, a law was passed in Philadelphia that allowed the city to purchase food products and sell them directly to the public at cost. In Baltimore, Maryland, the government implemented a program in which twenty-four 5-ton trucks from various city departments were sent into the countryside to purchase foodstuffs directly from farmers. The money paid to the farmers was taken out of the city's contingency fund, and officials hoped that the action would cut market prices by twenty-five percent. ${ }^{24}$

City officials in New York responded first by ordering the Health Commissioner to conduct a study on food conditions. He examined four issues as they related to the price of food, and his findings were published in a report that was released on February 25th. First, the commissioner looked for evidence of hoarding or speculation by surveying the stores of perishable foods within the city. He found that, in general, the

\footnotetext{
23 "Our Food Problem," The New Republic, July 14, 1917, 290; "'Feed America First': Slogan of Food Embargo Organization at Work in St. Louis," New York Times, February 23, 1917; "Food Riots in the United States," The Literary Digest, March 3, 1917, 533-534.

24 "Bill for City Purchases," New York Times, February 26, 1917; "City Buying for Baltimore," New York Times, February 26, 1917.
} 
amount of perishable foods held were no more than usual, and thus hoarding could not be the cause of the high prices. He also investigated the claim that retailers were pushing up prices by comparing wholesale and retail prices of staple foods. His findings showed that retailers were making no more than a reasonable profit and thus could not be blamed for the cost of food either. He then looked at the overall export of staple crops from 1914 to 1916 . The findings supported the claims made by the Times editorial which pointed to demand abroad as the major culprit. Figures showed that there was a dramatic increase in the amount of food going overseas while at the same time no real corresponding increase in production. This, according to the commissioner, was the chief cause of rising food prices in New York. ${ }^{25}$

Despite finding the source of rising prices, the report called into question the actual seriousness of the food situation facing working class residents of New York. While continuing price increases could lead to a crisis, there appeared to be no current emergency in the food situation. Indeed, some left-leaning media outlets criticized the "highly colored" accounts from the mainstream press. They suggested the motivation behind such exaggerated reporting was to either portray the working class as a threat to internal security, or to somehow awaken the nation to the growing threat posed by the Central Powers. The final matter examined by the commissioner involved a detailed study of the economic condition of a sample of over twenty-five hundred families that were under the supervision of the city's Health Department. While investigators did find that in general families had experienced a reduction in the amount of food consumed,

\footnotetext{
25 The United States had experienced a dramatic increase in demand for food overseas almost from the outset of hostilities in 1914. As would be the case in 1917, the major sources of this demand in the years leading up to the American declaration of war were western European nations such as Britain and France; "Emerson Attributes Food Rise to Exports," New York Times, February 26, 1917.
} 
they found "no complaint of want" in over 1800 families. "It was not uncommon," claimed the report, "that the surroundings or equipment of the home contradicted the claim of urgent need for relief." If a family had experienced food insecurity it was the result of unintelligent or uninformed purchases based on habit and racial customs. The report gave an example of a family of eight on a $\$ 15$ per week food budget "indulging in the luxury of imported Italian cheese at $\$ 1$ a pound." According to officials, if a working class family was struggling to keep food on the table, it was just as much their own fault as anyone else's. ${ }^{26}$

Thus, the report concluded that the present conditions could not be altered by any system of direct relief given by the city. The most effective solution involved a combination of expanding existing programs like the school lunch program, relaxing laws that restricted the sale of certain types of food like skim milk and bob veal, and a public education program in "matters of the selection and preparation of food." An example of the latter was evident almost immediately after the report was issued when the city began what it called a "rice crusade," which was an organized drive by the city to get citizens to purchase more rice. Rice at the time was cheaper than other grains, but was thought to not be popular among much of the working class. Children in the public school system were given a circular entitled "Facts About Rice" to take home to their mothers. "Use the information given in this circular to make your dollar go further," urged the handout. It touted the food value of rice, claiming that it had "more strengthgiving material" than the more popular potato. The flyer also included preparation

\footnotetext{
26 "Emerson Attributes Food Rise to Exports," New York Times, February 26, 1917; Bruno Lasker, "The Food Riots," The Survey, March 3, 1917, 638-640.
} 
suggestions, and asserted that, when combined with cheese and lentils, rice created a dish that could take the place of more expensive meat and potatoes. ${ }^{27}$

Food prices continued to be a major issue as Hoover assumed the position of prospective food administrator, and he was quickly confronted by the challenges he would face as he tried to balance the needs of the Allies with the realities at home. In order to more effectively transport food supplies overseas, Hoover had contemplated using steamers of the United Fruit Company, which transported fruit from Latin America. However, by the spring, New York City appeared once again to be on the verge of social unrest. On the Lower East Side, the food committee of the East Side Protective Association claimed that food prices were continuing to soar and warned of impending riots if prices were not checked. Responding to Hoover's proposed plan, Maurice Eckstein, a representative from the New York Mayor's Food Supply Committee, urged him to reconsider. Eckstein claimed that city officials had been fighting off unrest since last February, and to take away the steamers would "bring us face to face with a situation already difficult to combat." Ships such as those of the United Fruit Company helped provide cheap food to the city's working class, and Eckstein urged Hoover to "use your good offices to prevent a single vessel carrying bananas to this country from being diverted to any other services."28

Congressman Fiorello LaGuardia from New York discussed before the House of Representatives the extreme conditions associated with the food shortages in his

\footnotetext{
27 "Emerson Attributes Food Rise to Exports," New York Times, February 26, 1917; Bob veal is the meat of days-old calves; usually the male offspring of dairy cows.; "Rice Crusade Begins," New York Times, February 26, 1917.

28 Letter, M. Maurice Eckstein to Herbert Hoover, May 28, 1917, Records of the United States Food Administration, Record Group \#4, 12HA-A11, Box 490, National Archives, College Park, MD; "Hunger Goads East Side," New York Sun, May 28, 1917.
} 
district. A number of charitable organizations in the city had contacted LaGuardia to report on the situation and advocate for the passage of food control legislation. Since the beginning of the year, the price of potatoes had increased by seventy-five percent, while bread was fifty percent more expensive. Even the most staple of products had become so expensive that workers were becoming ill due to lack of food. What LaGuardia found particularly troubling was that complaints were not only coming from his poorer constituents. Food insecurity was beginning to creep into the ranks of the middle class. "The meatless diet of the Siberian peasant and the rice meal of the Chinese cooly," declared the lawmaker, "have supplanted the roast beef and the pie of the average American."29

Not only had the increasing cost of food moved beyond the poorer and working classes by the spring of 1917 , the issue of prices and the threat of unrest had spread beyond metropolitan areas like New York City. An editorial in the Wilkes-Barre Record claimed that local consumers and retailers were suffering high prices at the hands of food pirates, while a New Jersey farmer claimed the prices he was receiving for his crops were so low that it was almost not worth it for him to harvest and sell them. A president from a drilling company in Kansas contacted Hoover to explain conditions as he saw them in his home state. State and local attempts to control prices and prevent speculation were not working. According to him, various trusts were at the center of the controversy, and if federal action was not taken, things could get out of hand. "If some one don't act soon," warned the businessman, "the people will, and it won't be the trust

\footnotetext{
29 "Remarks, House of Representatives on Lever Bill," 65th Cong., 1st sess., Congressional Record 55 (June 21, 1917): 4015.
} 
they will break, but the necks of some of the leaders who are now working to destroy every common man and this country."30

Concerned citizens throughout the country contacted Hoover to let him know about the suffering caused by high food prices and offer up what they viewed as the source of the problem. For many, it was a matter of the "moneyed" classes taking advantage of the "laboring" classes. The prospect of class warfare seemed all too real based on the letters of apprehensive individuals. "Each day that Congress delays action in the food situation," warned one man from rural Virginia, "the man already made poor by the food grafter is becoming poorer and the oppressor richer." The local newspaper had launched an investigation on food prices and caused a stir when it printed wholesale and retail prices. The editor of the Bristol Herald Courier requested the aid of Hoover after local retailers threatened legal action against the paper. Life for the working class had become unbearable in this town along the Tennessee-Virginia border, and observers claimed they were becoming "restive." At meetings workers claimed that the food situation was draining their "patriotic enthusiasm." For them, the "men of wealth" that were keeping food of their tables were a greater enemy than Germany, and they were on the verge of taking matters into their own hands. "I am frank to tell you that any day," wrote John Dove of Bristol, "in this little city alone, a regiment could be

\footnotetext{
30 "Charges Local Food Piracy," clipping, Wilkes-Barre Record, June 13, 1917, from letter, C.E. Ferguson to Hoover, June 13, 1917, Records of the U.S. Food Administration, Record Group \#4, 12HA-A11, Box 490, National Archives, College Park, MD; "Evidence of Rascality Furnished by a North Bergen Farmer," clipping, Hudson Observer, June 19, 1917, from letter, M. Foley to Hoover, June 19, 1917, Records of the U.S. Food Administration, Record Group \#4, 12HA-A11, Box 490; Letter, J.C. Collins to Hoover, June 23, 1917, Records of the U.S. Food Administration, Record Group \#4, 12HA-A10, Box 489.
} 
raised...who would be glad to aid in...putting the fellows who have made life hard for us where they belong." 31

In the eyes of many, the best solution to the food crisis was government intervention, and calls for a food control bill of some sort were coming from various segments of American society. A local Council of Defense in Florida passed a resolution calling on Congress to give the president various powers as it related to the nation's food supply, including the power to require all businesses and private households to furnish the government lists of food in their possession and even the power to confiscate food to distribute to people at cost. Arthur Capper, the governor of Kansas, appealed to Vice-President Thomas Marshall to advance government food control as a measure second only in importance to legislation dealing directly with the military. The governor felt compelled to act due to the constant appeals from people who were suffering from high food prices. An editorial in the New York American argued that government food control was the "country's most urgent war need." According to the paper, such legislation was perhaps the only way for the U.S. to preserve itself and its own people. ${ }^{32}$

Thus, as Congress began to debate the legislation proposed by the Wilson administration the cost of food at home was front and center. Even before Hoover had

\footnotetext{
${ }^{31}$ Letter, John Dove to Hoover, June 11, 1917, Records of the U.S. Food Administration, Record Group \#4, 12HA-A10, Box 489; Letter, Walter Harper to Hoover, June 18, 1917; Records of the U.S. Food Administration, Record Group \#4, 12HA-A10, Box 489.

${ }^{32}$ After the U.S. declaration of war, the president urged each state to create their own Councils of Defense to assist in the coordination of resources being carried out at the federal level; "Food Supplies," 65th Cong., 1st sess., Congressional Record 55 (April 30, 1917): 1565; 65th Cong., 1st sess., Congressional Record 55 (May 18, 1917): 2498; "Absolute Food Control by the Government is the Country's Most Urgent War Need," New York American, May 25, 1917, from 65th Cong., 1st sess., Congressional Record 55 (May 28, 1917): 3002-3003.
} 
arrived in the United States from Europe, the bill that would become the Food Control Act began its journey in Congress. At the end of April members of the House Committee on Agriculture began consideration of possible legislation, while serious discussions over the food issue started in the Senate at the beginning of May. Some senators charged that the failure to act would eventually result in severe food shortages. "In my judgement," declared Senator William Borah of Idaho, "the most serious and stupendous fact which confronts us today with reference to the question of war is that of food." If the war were to last beyond two years and the public failed to respond by conserving food, the senator warned that the nation would "face a real famine." In addition to encouraging the collective sacrifice of the American people, Borah and others felt the government also had to take action against food speculators, whom they felt were the primary cause of high prices and should be considered the nation's true enemy. Borah went so far as to crassly suggest that the best way to deal with speculators was to "string them to lampposts or put them behind prison bars." 33 The bill proposed by the president and his supporters bestowed upon the executive branch the power to regulate the supply and price of certain crops, such as wheat, through government corporations. In addition, the legislation called for the creation of a new agency that would not only work to control the production end of the food supply, but would also be involved in the elimination of hoarding and profiteering among retailers, as well as the promotion of conservation and substitution among American consumers. While Wilson and Hoover believed that achieving the goals of increased production and reduced consumption of food on a national scale would

\footnotetext{
${ }^{33}$ Mullendore, History of the United States Food Administration, 48-51; "Food Speculators Assailed in Senate," New York Times, May 3, 1917.
} 
ultimately require very little government coercion, the limits placed on the power of the president to forcefully tell Americans what they could grow or eat were blatantly vague. ${ }^{34}$

The legislation was reported from the House Agricultural Committee by its chairman Asbury Lever of South Carolina on June 11th and debate on the Lever Bill (as it came to be known) opened in both houses on June 18th. Lever, in his opening remarks, reminded his colleagues that the nation was at war with Germany, "the most thoroughly organized and autocratic military nation on the face of the earth." Reflecting the belief that success in modern warfare relied just as much on home front efficiency as it did on battlefield strategy, the Congressman asserted that an unorganized democracy had no shot against an autocracy like Germany. To achieve such organization, Lever felt steps needed to be taken that would encourage production, streamline distribution and encourage conservation. Without the executive authority granted in the proposed bill, "the same chaos and confusion and waste and lost motion and manipulation and sky-rocketing prices of the past few months will only be exaggerated and increased." While acknowledging that the powers granted were unprecedented, Lever followed by arguing that the challenges facing the nation were unprecedented and speculated that if the powers were not granted, Americans should be prepared to "have them assumed by the German Kaiser."35

While the food control bill's namesake declared that all Americans should be prepared to sacrifice by conserving food for our Allies, he also pointed out the problems

\footnotetext{
${ }^{34}$ Zieger, America's Great War, 72; Kennedy, Over There, 123.

35 Mullendore, History of the United States Food Administration, 51-56; "Remarks, House of Representatives on Lever Bill," 65th Cong., 1st sess., Congressional Record 55 (June 18, 1917): 3792-3795.
} 
surrounding the price of food at home. According to Lever, the high cost of food was part of an overall dramatic rise in the cost of living over the past decade. Generally speaking, the numbers backed up the lawmaker's claim. From 1907 to 1916, retail prices increased thirty-nine percent. The wages for the average American worker, however, were not keeping up. Wages in the U.S. over the same period had only increased nineteen percent. Lever relayed the message he received from a woman in Philadelphia, who could not afford the twenty-two cents to purchase a pound of the humble shin of beef, a product that previously cost two cents per pound. "Twenty-two cents per pound for a soup bone," wrote the struggling woman, "may make dangerous men and women out of ordinarily peaceful and good citizens." The solution according to Lever was food control. To support his claim, he pointed out the fact that food prices in war-torn countries like Germany and England, where famine was imminent but also where food control measures were already in place, were equal to or less than prices in the U.S. ${ }^{36}$

Despite the fact that Lever's opening comments on his food control bill were warmly received by most of his fellow House members, a vocal minority, composed of a mix of Republicans and southern Democrats, was quick to assert itself by calling into question many aspects of the proposed legislation. Representative James Young of Texas was one of the first to express misgivings about the bill, and his views would come to be reflected by many of the bill's critics. He argued that the legislation was unconstitutional and that if passed it would essentially permit the president to bring a food dictator to the nation's capital. The powers granted by the Lever Bill were too

\footnotetext{
36 "Remarks, House of Representatives on Lever Bill," 65th Cong., 1st sess., Congressional Record 55 (June 18, 1917): 3795-3798.
} 
general and vague in nature, and thus potentially too far-reaching in their scope. "No American citizen," argued Young, "knows when he wakes up in the morning whether overnight he has not become a felon under the provisions of the bill." In his eyes, the government should keep away from the actions of producers and consumers and focus its attention on the middlemen and distributers, who were the main source of high prices. Once the government successfully brought prices down, Young argued, the patriotism of American consumers and farmers would kick in and allow the nation to feed the Allied countries without any further government interference. ${ }^{37}$

In the Senate the bill was introduced by Democratic Senator George Chamberlain of Oregon, and Senator James Reed, a Democrat from Missouri, led the opposition. Echoing much of Congressman Young's sentiments, Reed expressed concern about the vagueness of powers granted by the bill to the president beyond the reach of Congress. Such powers, claimed the Senator were "greater than has ever been exercised by any king or potentate of earth and broader than that which is exercised by the Kaiser of the Germans." Senators Hardwick of Georgia and Gore of Oklahoma also called into question the constitutionality of the measure, in particular the role of food administrator, which was to be filled by Hoover. Rather than an administrator, the bill would create a "food dictator," who could theoretically fix prices and control supplies. Gore proclaimed that, unless major changes were made to the bill, he could not vote for it. "I cannot support features," exclaimed the senator from

\footnotetext{
37 "Remarks, House of Representatives on Lever Bill," 65th Cong., 1st sess., Congressional Record 55 (June 18, 1917): 3808.
} 
Oklahoma, "that put the control of all the nation's food supply in the hands of one man."38

Reed expressed misgivings about Hoover specifically, pointing out the fact that he had spent much of his adult life abroad, which called into question his qualifications for dealing with such important questions affecting the American people. He concluded his opening comments with the following dramatic declaration:

I protest against the bill as a mistake, and economical mistake. I protest against it as an offense against the Constitution of the United States. I proclaim it to be an invasion of our Bill of Rights. I declare that it will produce that paralysis of business and energy which will make it impossible for us to finance the armies of the world and to feed the nations who are our allies in the great struggle now engulfing mankind.

Thus, the Lever Bill would not only threaten the very sanctity of American democracy, if passed it would produce an outcome in direct opposition to its intent. It was clear that the Lever Bill was up against determined opposition in both houses, and observers predicted that the legislation would not make it out of the House without the addition of amendments that would check the power of the head of the Food Administration while in the Senate it was a real possibility the measure would face a filibuster. ${ }^{39}$

The White House appeared to be well aware of the potential roadblocks its proposed legislation would face, so the president attempted to seize the upper hand in the public debate over the issue of food control. The same day that debate over the

\footnotetext{
38 "Remarks, House of Representatives on Lever Bill," 65th Cong., 1st sess., Congressional Record 55 (June 14, 1917): 3595-3601; "Wilson Warns Foes of Food Bill of Nation's Blame," New York Times, June 19, 1917.

39 "Remarks, House of Representatives on Lever Bill," 65th Cong., 1st sess., Congressional Record 55 (June 14, 1917): 3595-3601; "Wilson Warns Foes of Food Bill of Nation's Blame," New York Times, June 19, 1917.
} 
Lever Bill opened in both houses of Congress, President Wilson served notice to critics of the measure in an open letter to Congressman Borland. Wilson first wanted to set the record straight on the primary goal of the bill. He asserted that references to the legislation as a "Food Control" bill was inaccurate and misleading. The objective of the Lever Bill, according to president, was not to have the government control food supplies, but to seize control away from speculators. He went on to issue a warning to critics. Their actions would not only potentially be seen as unpatriotic, but they would also contribute to the continued suffering of the nation's working class. By delaying passage of the Lever Bill critics such as Senator Reed and Congressman Young were opening themselves up to the charge that they were putting the interests of a few above the interests of the nation as a whole. Further, they could be seen as the major cause of even higher food prices. He closed by drawing a line in the sand, marking the date of July 1 st as a deadline for final approval. 40

Meanwhile, Hoover did what he could to keep tabs on the public debate over the Lever Bill. In the days following its introduction on the floors of Congress, Hoover's staff provided him with periodic memorandums that contained press clippings from the nation's major papers and a summary analysis of the press coverage surrounding the legislation. The prospective head of the U.S. Food Administration was told that most of the "big Eastern papers" supported government action, while several editorials and cartoons had shown that "our effort to bring the situation home to Congress" had been appreciated by the country. Should Hoover decide to more directly influence public debate using the press, several editors had expressed the "utmost desire to cooperate."

40 “Wilson Warns Foes of Food Bill of Nation's Blame," New York Times, June 19, 1917. 
Further, he was told that the Food Administration could "easily place a column of instructions to the American public in regard to food conservation and get all of it printed." Not only was such a relationship viewed as key in getting the Food Administration measure passed, it would continue to have importance once the Lever Bill became law. Agencies such as the Newspaper Enterprise Association, which reached nearly 9 million readers daily and gave enthusiastic support to the Food Administration, would end up becoming "an invaluable agency for the distribution of our publicity matter." 41

Despite the appearance of a concerted campaign by the press to bring pressure on Congress to pass the Lever Bill, Hoover was also informed of efforts by certain interests that might be negatively impacted by the measure to prevent its passage. While most of the editorial coverage of Senator Reed's attack on the Lever Bill was "scathingly critical," the New York World and the New York Evening Sun supported Reed and filled their pages with sharp disapproval of the Food Administration measure. While the New York World in its coverage warned of a food dictatorship and widespread hunger if the Lever Bill became law, the Evening Sun declared that the bill would create a "political, social, and economic revolution...a despotism."42

As stated previously, the supporters of the Lever Bill recognized and appreciated the point that the measure created a considerable increase in centralized power. However, whereas critics felt this increased power threatened to undermine democracy,

\footnotetext{
41 "Memorandum for Mr. Hoover," June 13, 1917, "Memorandum for Mr. Hoover," June 18, 1917, "Memorandum for Mr. Hoover," June 21, 1917, United States Food Administration Records, Box 2, Folder 1, Hoover Institution Archives, Stanford University.

42 "Memorandum for Mr. Hoover," June 19, 1917, "Clippings for Mr. Hoover," June 19, 1917, United States Food Administration Records, Box 2, Folder 1, Hoover Institution Archives, Stanford University
} 
supporters like Hoover felt such temporary action was necessary to preserve democracy in the long run. To get this point across to the public, Hoover looked to history. He contacted Ida Tarbell, the well-known progressive journalist who was then serving in the Women's Committee of the National Council of Defense. "A great deal is being said about the undermining of democracy by passing legislation of the nature of the Lever Food Bill," wrote Hoover. He looked to Tarbell, whom he considered an expert on the life and words of Abraham Lincoln, for examples of references made by the great Republican leader on the necessity of increased centralization of authority in the federal government during times of war. Hoover thought that such information would be helpful to "bring home to our people that these emergency methods have not shaken the foundation of the Republic hitherto and have the sanction not only of experience but of our greatest national leader." After providing Hoover with a number of specific examples from the Civil War president, Tarbell advised him that he could "say as strongly as you wish that Mr. Lincoln believed that any amount of centralization necessary to save the country in an emergency was justifiable and to him it would be unthinkable that the Lever Food Bill...would undermine Democracy."43

The day after debate on the Lever Bill was opened in Congress, Hoover appeared before the Senate Agricultural Committee. He once again emphasized the need for food control legislation given the extraordinary circumstances both at home and abroad. Americans were facing increasing food prices and decreasing supplies

\footnotetext{
43 Letter, Hoover to Ida Tarbell, May 29, 1917; Letter, Tarbell to Hoover, June 5, 1917, United States Food Administration Records, Box 46, Folder 9, Hoover Institution Archives, Stanford University; Tarbell, best known for her "muckracking" work that exposed the social ills of industrialization with critical studies of the likes of John Rockefeller and his Standard Oil, first gained notoriety for her scholarship on Lincoln. First published in serial form in 1895, her biography of the president was published as a book in 1900. See Ida Tarbell, The Life of Abraham Lincoln: Drawn from Original Sources and Containing Many Speeches, Letters and Telegrams Hitherto Unpublished, 2 vols. (New York: Doubleday and McClure, 1900).
} 
while our allies were facing famine and defeat at the hands of the dreaded Germans. Hoover felt any question of whether the Lever Bill should become law were answered given such desperate conditions. He claimed that under normal circumstances, the United States could only supply sixty percent of the needs of the Allies. If the forty percent deficiency was to be made up, cooperation from both sides of the Atlantic was needed. Americans needed to make their kitchens more efficient and less wasteful, while the people of the Allied nations needed to continue their self-denial. Failure to act on the Lever Bill would not only result German victory in Europe, but also social disruption at home. Hoover claimed that the revolution that recently kicked off in Russia was at least in part the result of food problems, and if its political leaders failed to act, the United States could face a similar fate. ${ }^{44}$

Given the relatively minor resistance to the measure in the House, it is no surprise that the Lever Bill passed by a vote of 365 to 5 on the twenty-third of June. However, the bill had been amended to include a prohibition provision that halted the manufacture of liquors for the duration of the war and authorized the president to seize existing stocks of distilled spirits. In addition, the amendment prohibited the use of any foodstuffs in the manufacture of all alcoholic beverages. As a result, the measure faced much stiffer opposition in the Senate, and debate over the Lever Bill dragged on well beyond the July 1 st deadline that had been established by President Wilson. ${ }^{45}$

\footnotetext{
44 "Bulletin No. 1," United States Food Administration, Washington, DC, Government Printing Office, 1917, from United States Food Administration Records, Box 401, Folder 6, Hoover Institution Archives, Stanford University.

45 "Food Bill Passed, With Prohibition Clause, 365 to 5," New York Times, June 24, 1917; Mullendore, History of the United States Food Administration, 51-56.
} 
There were several issues that prolonged the Senate debate. In addition to consideration of the House prohibition amendment, members debated the inclusion of amendments that covered non-food items such as steel, cotton and other commodities. Critics such as Senator Reed continued to question the very constitutionality of the food conservation measure, especially as it applied to the proposed government involvement in Americans' consumption habits. In a blistering speech delivered in the middle of July on the Senate floor, Reed persisted in his assault on the proposal that one man have so much control over the nation's food supply. He set his sights on the mining engineer and "launched the bitterest attack he has yet made upon Herbert C. Hoover." Calling Hoover an "arch gambler," Reed questioned his loyalty to America and accused the former head of the Commission for the Relief of Belgium of rigging food markets to drive prices down in Europe, an action the senator claimed had consequently driven food prices up in the United States. ${ }^{46}$

Reed once again questioned Hoover's ability to relate to the American situation since he had lived abroad for so long, working on various mining operations throughout South America, Europe and Asia. "He's been so long away that he is quite a stranger here," claimed the senator from Missouri. He suggested it was within this climate of overseeing operations and ruling over scores of foreign workers in remote sites that Hoover acquired the knowledge and desire to be "supreme boss to regulate the diet of the American people." Further, Reed took issue with Hoover's self-described political leanings, pointing out that he had been quoted as describing himself as "a liberal--not a Republican, or a Democrat, or a Populist, but a Liberal." It was due to these misgivings

46 "Attacks Hoover as Arch Gambler," New York Times, July 17, 1917. 
that Reed proposed an amendment to the Lever Bill that would create a board of five individuals to replace the single head administrator. As another jab to Hoover, Reed suggested a further provision that all five members had to be resident civilians. With this assault Reed made it clear that the Lever Bill would be facing a steep uphill climb in the Senate..$^{47}$

Amid the Congressional debates, the criticisms, the amendments and substitute bills, Hoover worked diligently to ensure that the Lever Bill reached the president's desk in its original form as quickly as possible. Hoover's concern was evident from his correspondence with the White House as the measure slowly made its way through Congress. Hoover continued to stress the importance of the voluntary nature of most of the conservation measure and informed the president that he had received word that the proposed bill had been well-received from several food trade organizations. "If we apply the powers of the bill," assured Hoover, "it will be with the approval of most of the well-thinking men in the trade as against the selfish and avaricious members." 48

The president's chosen head of the Food Administration expressed particular alarm with the proposal first brought forth by Senator Reed that would replace a single head of the agency with an advisory board. Such an arrangement, according to Hoover, would "destroy the whole question of the imaginative side of leadership of yourself and sense of volunteer service in the interest of the Nation, which is absolutely critical in order to amass the devotion of the people." Bills that contained such a provision were offered up by Senators Hollis and Gore, and Hoover quickly advised the president to

\footnotetext{
47 "Attacks Hoover as Arch Gambler," New York Times, July 17, 1917.

${ }^{48}$ Letter, Hoover to Wilson, July 12, 1917, United States Food Administration Records, Box 5, Folder 1, Hoover Institution Archives, Stanford University
} 
distance himself from these substitute measures. In order to inform lawmakers that the Lever Bill was still the preferred legislation of the White House, Hoover constantly had memos drawn up that illustrated the various shortcomings of the substitutes. Most importantly, an agency led by a commission would be dangerously slow to react. A three- or five-member board would likely require unanimous decisions and lead to inefficiencies and internal friction, which, according to Hoover, would undermine the unity of purpose that was required in a time of war. Further, members of a committee or advisory board would likely require some level of financial compensation. Hoover reminded the president why he decided to come home and serve as the head of the Food Administration on a volunteer basis. "For me as a volunteer making sacrifices," said Hoover, "to ask the most modest household to join in this sacrifice meets a response entirely unapproachable from a paid servant of the Government." 49

Indeed, despite the fact that the Lever Bill had yet to be passed, Hoover had already begun asking American households to sacrifice. Back on June 16th, Wilson instructed the food crisis expert to begin the construction of a voluntary conservation program aimed at the public. "While it would in many ways be desirable to wait complete legislation establishing the food administration," wrote the president, "it appears to me that so far as voluntary effort can be assembled, we should not wait any longer." By the middle of July, the Food Administration had created "voluminous propaganda" on issues of conservation of waste, but at the time Hoover was concerned about its effectiveness and ability to "keep in proper tune." He hoped to bring in George

\footnotetext{
49 Letter, Hoover to Wilson, July 12, 1917; Letter, Hoover to Wilson, July 18, 1917; Letter, Hoover to Wilson, July 22, 1917, United States Food Administration Records, Box 5, Folder 1, Hoover Institution Archives, Stanford University.
} 
Lorimer, editor of the Saturday Evening Post, to oversee future propaganda operations. While Hoover expressed frustration, Wilson urged patience for the procedures of Congress. The president assured Hoover that he was watching the proceedings carefully and assured his chosen administrator that the Lever Bill would emerge from conference "with practically the provisions we have all along urged." "It is a tedious and vexatious process," lamented Wilson, "but necessary to be endured."50

While Hoover was largely working behind the scenes throughout the summer to advocate for passage of the Lever Bill, the editorial pages of the New York Times very publicly expressed its support for the administration's food conservation measure. The arguments made by the nation's most influential daily mirrored Hoover's and the bill's various Congressional champions. Depicting the bill as a war measure, the Times described the nation's current position as "perilous" and argued that food conservation was "essential" to ensure the country's safety. The Lever Bill, they argued, was a "war measure as essential to our success as army and navy extension." While the powers granted the president were real, the editors felt they were necessary given the demands of war and the unbearable food situation. "In these abnormal times," wrote the editors, "the expedient of careful food administration must be resorted to." The Times cited the support of organized labor as proof that the public was lending its support to the measure. ${ }^{51}$

\footnotetext{
50 Mullendore, History of the United States Food Administration, 51-56; letter, Wilson to Hoover, June 16, 1917, reprint, "Bulletin No. 1," United States Food Administration (Washington: Government Printing Office, 1917); While Mullendore claims the letter from Wilson to Hoover was written on June 12, the reprint in "Bulletin No. 1" was dated June 16; Letter, Hoover to J.P. Tumulty, July 20, 1917, Letter, Wilson to Hoover, July 19, 1917, United States Food Administration Records, Box 5, Folder 1, Hoover Institution Archives, Stanford University.

51 "Pass the Food Bill," New York Times, June 16, 1917; "Food Control Essential," New York Times, June $17,1917$.
} 
When it came to commentary on the opponents of the Lever Bill, the media at first virtually ignored those who criticized the administration's plan for food conservation. The Times confidently predicted that passage of the measure was assured if Congressional opposition was "nothing more serious than the oratory of Senator Reed." Labeling the Missouri lawmaker as a "chronic objector," the paper asserted that all of the arguments that were brought forth by Reed had been soundly discounted. However, as the president's July first deadline came and went and the very nature of the Lever Bill faced threats from various amendments and substitutes, the tenor of the Times argument grew more urgent. The paper argued that amendments covering items such as alcoholic beverages, cotton, and steel were largely the work of obstructionists who wanted to make the bill as unappealing to as many people as possible. "Lobbying has not been more scandalous in Washington in a long time than since this bill reached the Senate."52

Part of the problem, according to the Times, was that opponents of the bill had effectively launched a coordinated campaign to confuse the public about the bill's purpose. The editors expressed regret over the fact that the measure was widely referred to as the "Food Control Bill" and not given a name such as the "Food Conservation Bill" that not only better reflected the purpose of the legislation but would have also led to a clearer comprehension by the general public. However, opponents of the bill had seized control of the debate, and as the nation celebrated its independence the fate of the Lever Bill was still very much in the air. On July 5th, the Times argued that continued delay was imperiling the safety of the nation, but expressed hope that the

\footnotetext{
52 "Pass the Food Bill," New York Times, June 16, 1917; "The Food Bill Delay," New York Times, June 28, 1917, "Perilous Obstruction," New York Times, July 4, 1917.
} 
Senate would "give its mind only to the country's need" and pass the bill by the end of the week. As the pressure mounted, Hoover made an attempt to ensure that the limited work already being conducted by the Food Administration was such that it could not provide fuel to the firestorm being created by his critics. He instructed his staff to send all conservation propaganda to the office of Edgar Rickard for censorship. "There are so many currents that need to be guarded against," wrote Hoover, "that for the present I think the whole office better go through one hand." One issue he was particularly concerned with was associating the work of the agency with one person, so he ordered that terms such as "Hoover's pledge" and "Hoover's Rules" be removed from all forms of publicity. The message that the government's suggestions for altered food behavior was coming from one person would only confirm the worst fears expressed by the likes of Senator Reed. "Nothing," warned Hoover, "is or will be more fatal in the long run." 33 However, the Times' hopes were not realized. The Lever Bill did not pass the Senate until July 21 st. Further, the original character of the legislation was drastically altered by amendments, including a provision for fuel and fertilizer control, limitations on the licensing power of the Food Administration, and, most importantly, the replacement of a single head for a committee of three. Hoover quickly let the president know that the bill passed by the Senate was inadequate and prepared a series of memos that addressed the shortcomings of the structure of administration proposed by the Senate bill and provided specific alterations that were required to "affect adequate food control."

\footnotetext{
53 "Pass the Food Bill," New York Times, June 16, 1917; "Food Control Essential," New York Times, June 17, 1917; Ray Lyman Wilbur, memorandum, undated, United States Food Administration Records, Box 7 , Folder 12, Letter, Hoover to Wilbur, July 21, 1917, United States Food Administration Records, Box 7 , Folder 13, Hoover Institution Archives, Stanford University; Rickard was Hoover's assistant Food Administrator and filled in as acting head whenever Hoover had to leave the country.; "We Must Have the Food Law," New York Times, July 5, 1917.
} 
Further, while Hoover continued to follow the lead of the president by keeping quiet and allowing the legislative process to play out, he feared that the delays in Congress and continued rising food prices might be incorrectly laid on the Food Administration. "I think we should reserve the right to say something rather loudly, later on," declared Hoover, "as we may have to face a perfect storm from the consumers of this country." 54

The Senate food bill was sent to the joint Congressional committee on July 25 , and the legislation once again became bogged down over details. The major sticking point was the nature of the agency's leadership, House leaders maintained a single head was the best approach while a powerful faction in the Senate led by Reed continued to push for a three-man board. As July came to an end, the president became more active in the legislative process, meeting with lawmakers to try and break the deadlock. The Senate finally agreed to accept a single leader for the Food Administration in exchange for the addition of a provision that would subject the president's choice to Senate confirmation. However, the House faction resisted, fearing that Hoover would not be confirmed. Wilson once again spoke up and expressed his strong opposition to any bill that did not allow him to choose the head of the Food Administration. The Senate finally agreed on the final day of July to eliminate the provision setting up a three-man board to head the agency. 55

\footnotetext{
54 Mullendore, History of the United States Food Administration, 51-56; Letter, Hoover to Wilson, July 22, 1917, United States Food Administration Records, Box 5, Folder 1, Letter, Hoover to Wilson, July 26, 1917, United States Food Administration Records, Box 5, Folder 3, Hoover Institution Archives, Stanford University.

55 Mullendore, History of the United States Food Administration, 51-56; "New Deadlock Over Food Bill," New York Times, July 30, 1917; "President Wins; Hoover to be Sole Food Controller," New York Times, July 31, 1917.
} 
While this cleared the way for Hoover to become the head of the Food Administration, the joint committee continued to butt heads over one remaining issue: an amendment that called for the creation of a Congressional War Advisory Board. Supporters of the amendment, mostly from the Senate, believed it was a way to check the power of the president in executing of the war, while the provision's opponents argued that such a board would not only reduce the role of Commander-In-Chief to a mere figurehead but also negatively impact the efficient execution of the war. It had been a month since the deadline established by the president was eclipsed, and as the debate dragged on, things became more heated. Senators Gore and Reed continued to assail the Lever Bill and Herbert Hoover, while the legislation's supporters responded with attacks of their own. The likes of Gore and Reed were compared to anarchists and their actions labeled as obstructionist. In delaying the bill's passage, critics of the Lever Bill were accused of supporting the cause of the enemy by limiting the ability of the president to effectively execute the nation's war strategy. ${ }^{56}$

The Lever Bill finally emerged from the joint conference bill on the third of August, minus the Advisory Board amendment. In fact, with the exception of provisions for fuel and fertilizer control, all amendments added to the original Lever Bill were eventually eliminated. The House quickly passed the measure by a vote of 357-0. The bill was approved by the Senate five days later with a vote of 66-7. The law granted the president the authority to create the U.S. Food Administration and to choose its head officer. In terms of the specific powers granted to the agency by the legislation, the

\footnotetext{
56 "Still Deadlocked Over War Board," New York Times, August 1, 1917; "Food Bill Passes; Its Foes Assailed," New York Times, August 4, 1917; "Says Gore Knifed Food Control Bill," New York Times, August 7, 1917.
} 
language was purposefully broad and vague. In addition to being given the authority to "organize the service and self-denial of the American people" regarding food conservation, which will be the focus of this study, the law also gave the agency limited power to control the distribution of certain foodstuffs at the wholesale level, as well as monitor and prevent hoarding and speculation. The Food Administration was also granted a limited ability to exercise control over the import and export of foods through the War Trade Board, as well as over the purchase of food by the Allies. President Wilson signed the bill into law on August 10th, and on the same day issued an Executive Order officially establishing the U.S. Food Administration and naming Herbert Hoover as its head. .57

In many ways, the measure was unprecedented. Never before had the federal government had so much control over what people were eating. Despite the vocal objections from those who feared the expansion of executive power, the extreme conditions created by a global war combined with an unwavering faith in American democratic institutions, allowed supports of the Lever Bill to eventually gain the upper hand. A major obstacle had been overcome and the president now had the power and authority to influence and guide the production, distribution, and consumption of the nation's food supply. However, while the U.S. Food Administration possessed the ability to directly impact production and distribution, the goal of conserving food by altering the nation's food consumption habits would have to be achieved with the voluntary cooperation of the American public. In order to achieve this objective, Hoover and the Food Administration employed a massive publicity/education campaign that set out to

${ }^{57}$ Mullendore, History of the United States Food Administration: 3-5, 59-60, 
reach each and every American in all possible settings, from the kitchen to the station, from the state fair to the movie theater. The next chapter will begin the examination of this conservation campaign by looking at U.S. Food Administration propaganda that was geared towards the American home. 


\section{Chapter 2 - "Awakening the War Consciousness of the American People"}

Even before the United States had officially declared war on Germany, Herbert Hoover recognized the importance America's food supply would play in the ultimate outcome of the conflict. War mobilization, as well as the destructive impact of warfare itself, had dramatically reduced the productive capacity of America's future allies, England, France, and Italy. In addition, the conditions at sea had made it difficult for these nations to secure a reliable flow of foodstuffs from outside sources such as Australia, Canada, and Argentina. According to Hoover, if the United States were to enter into war with Germany (and by the Spring of 1917 it was looking more and more likely), its immediate and primary objective would be to provide an adequate food supply for its partners overseas. ${ }^{1}$

In order to achieve this goal, Hoover and his advisors believed that the consciousness of the American public had to be awakened. This chapter focuses on the aspects of U.S. Food Administration propaganda that targeted the emotions of the American public. It will examine how a large portion of the agency's message regarding the need for food conservation emphasized such stirring themes as patriotism and individual sacrifice. It will show how Food Administration propaganda sought to militarize the home front and secure total support from a population that was not directly affected by the conflict. To accomplish these goals, the government would rely heavily on the expertise from an emerging modern advertising industry that was based on appealing to people's emotions to sell a product or idea. The result of such a relationship would not only impact wartime food control propaganda. The Food Administration's program was

\footnotetext{
1 Herbert Hoover, "Notes on National Food Control - For Council Nat'l Defense"; undated; Box 1, Folder 2; US Food Administration Records, Hoover Institution, Stanford University.
} 
also an important factor in expressing the idea that total social cohesion was needed to achieve victory in modern war. Additionally, the nature of the Food Administration's propaganda machinery would sow the seeds of a relationship between government, advertisers, and experts in such fields as nutritional science that would take on greater importance in shaping American food culture during the twentieth century.

The subject of government propaganda in the United States during the First World War has received a good bit of attention from scholars. Particularly, historians have examined the tensions that existed between a growing federal government that required universal support among the population for the war effort, and an American public that held a general skepticism towards a powerful central authority and a specific ambivalence towards the nation's involvement in the First World War. Rather than reliance on measures that forced compliance with wartime measures, the U.S. government, and the various associated local, state, and private institutions, relied on "coercive volunteerism" to mobilize American society for war. Chris Capozzola and Robert Zieger have both looked at how the combined efforts of the government and private patriotic organizations militarized the home front by bringing the war to the people and created a climate in which Americans, even those not committed to military service, felt obliged to volunteer for the war. Capozzola concludes that this emphasis on "civic volunteerism" not only formed social bonds and emphasized political obligations, it served to organize public life and helped Americans feel a sense of collective identity. ${ }^{2}$

2 Christopher Capozzola, Uncle Sam Wants You: World War I and the Making of the Modern American Citizen (New York: Oxford University Press, 2008) 1-101; Robert Zeiger, America's Great War: World War I and the American Experience (New York: Rowan \& Littlefield, 2001) 20-75. 
Looking specifically at the actions of the Food Administration, one can see all of these forces at work. In addition to simply conserving food for the sake of sending supplies overseas, Food Administration officials were also committed to using the power of their agency to help create a collective national purpose as well as a general positive attitude towards the war effort itself. Additionally, some within the Food Administration saw their situation as an opportunity to foster long-lasting changes to the everyday habits of the American public. The belief among many was that the food conservation campaign could serve as a launching point for a longer-lasting campaign that promoted more efficient and economical behavior within every household. In her recent study of American food culture during the early twentieth century, Helen Veit contends that the war provided an opportunity for progressives, obsessed with the practice of moral behavior through rational science, to use the power of the federal government to change the way people ate. The Food Administration would bring together all of these strains of thought to produce a propaganda campaign that aimed to both shape the immediate wartime food choices of Americans and influence the nation's food culture on a more permanent basis as a means to create a more modern, efficient society. ${ }^{3}$

During the summer of 1917, while the Lever Bill was still being debated in Congress, Herbert Hoover and his staff began working tirelessly on crafting a message that would resonate with the American public. As previously stated, Hoover essentially saw the program of food conservation as playing out in two general stages. First, the government had to gain the attention of the American people and convince them that a food problem indeed existed. It would only be after such an awakening that the public

3 Helen Zoe Veit, Modern Food, Moral Food: Self-Control, Science, and the Rise of Modern American Eating in the Early Twentieth Century (Chapel Hill: UNC Press, 2013) 1-35. 
would then be receptive to specific instructions on changing their food behaviors. "If we can secure the emplacement of this idea in the minds of the people," claimed Hoover, "the sequent suggestions of constructive order which we may make will fall not only on a receptive mind but upon a convinced intelligence." The primary focus of this chapter is this first step: namely, the nature and extent of the portion of propaganda that dealt specifically with the way in which the government, via the U.S. Food Administration, worked to generate a message that would convince the public that a problem existed and arouse the volunteer spirit of the nation. ${ }^{4}$

Addressing the Council of National Defense in the Spring of 1917, Hoover shared his ideas regarding the issue of possible government food control in the United States. He acknowledged five different phases or levels of repression, each representing a different level of compulsion. There was the "rough rationing" which had been employed with sugar in England, where the government restricted what retailers could access and make available to consumers. The German government had implemented a system of coupon rationing, which restricted what consumers could purchase at stores. The government could also issue cards to each household, listing set maximums of certain foods that could be purchased. The most dramatic measure, however, would have been strict rations being distributed through government-controlled stores and kitchens. A system that had been implemented in war-torn Belgium, and thus a measure that Hoover was quite familiar with. 5

\footnotetext{
4 Letter, Herbert Hoover to News Publishing Co., August 10, 1917; Box 45, Folder 7, Stanford. 5 ibid.
} 
The final approach proposed by Hoover, and the one he felt best fit American society, was the indirect repression of food consumption. Essentially, the government would work to cultivate a certain food behavior among its people without compulsory measures. Hoover wanted to avoid a system of compulsory rationing. Rather, he believed it was possible to convince Americans to voluntarily follow government guidelines. There were two primary reasons cited by Hoover for favoring indirect repression, or "voluntary cooperation," over government-directed compulsion. The first was the economic burden that would come with administering and enforcing a compulsory rationing program. The second consideration placed the USFA program well beyond the immediate task of merely providing nourishment to a needy population. It reflected the overwhelming confidence Hoover and his progressive colleagues had in the fundamental nature of United States and its people. It was the opportunity to prove the ultimate worth of American-style democracy on a world stage. Rather than be forced to alter food behaviors at the command of some central authority, the American people, with the guidance of the federal government, would willingly, and freely sacrifice at the kitchen table to help defeat the autocratic German regime.

In order to keep with his guiding philosophy of "voluntary cooperation," Americans would be looked upon to willingly alter their eating behavior to fit the needs created by the wartime food crisis. There were several ways in which such indirect repression might be achieved, all of which became part of the official program of the U.S. Food Administration. The first involved the total suppression of certain imports, such as exotic fruits and vegetables. The second would be the suggested limitation of consumption via themed ordinance, such as "meatless" and "wheatless" meals and 
days. The government would also encourage the alteration of the production of certain foods, especially breads. Finally, Hoover stressed that the government should encourage the use of certain substitutes in place of foods deemed vital for export to Europe. One example he provided was the promotion of using vegetable fats in place of animal fats, and in order to make such products more appealing, the government could work to change the name of the product from the unappealing margarine to something more familiar like "nut-lard."6

To achieve such objectives, government-sponsored propaganda, or as it was often referred to, "publicity," was extremely important. Especially in this case, where the government was not demanding nor imposing a particular set of behaviors. Rather, the government would advise the public. It would awaken and then enlighten Americans via what Hoover termed "educational regulation." The U.S. Food Administration would make the American people aware of the global food problem, it would create an environment whereby Americans remaining at the home front would feel an obligation to comply, and it would education the population on how exactly to follow government guidelines and why such measures would ultimately not have a negative impact on the their health or well-being. ${ }^{7}$

Convincing people to cut back their consumption of staples such as bread, meat, and sugar, especially in the name of a war that was not wildly popular, was a fairly hard sell. However, rather than portray the food situation as a burden, Food Administration propaganda attempted to characterize it as an opportunity to serve the nation. The

6 ibid.

7 ibid. 
American household, and in particular the kitchen, became a battlefront. Even if they didn't join the military and ship off overseas, or didn't volunteer their services to various home front initiatives, Americans left behind could fight the war with their food choices. To accomplish such an onerous task, the government looked to an emerging modern advertising industry for assistance. Working closely with a number of advertising executives, the Food Administration generated a publicity campaign that utilized a variety of mediums that reached every part of American life, public and private, from the movie theater to the dinner table. The goal was to make people willingly change their habits without forceful government intrusion. The government did, however, find ways to make their presence felt in the American kitchen without assertive incursion.

The results of these forces coming together as the United States entered World War I would not only help shape the national consciousness as it related to American involvement in the conflict, it would also have a lasting impact on how the nation viewed its food system and perceived its food culture. Through the actions of the United States Food Administration and its various propaganda initiatives, food became much more than mere sustenance, or an indulgence, or even the expression of a particular culture. What someone ate became an expression of that person's patriotism, of his or hers commitment to the nation and the war effort. Moreover, the institutional machinery that was created to generate this new approach to food would have impacts far beyond the war. For the first time, a relationship between the government, the advertising industry, 
and nutritional experts was established that would continue throughout the rest of the century and generate the cultural force that has come to be known as "nutritionism."8

In order to stir the emotions of the American population, the government called on the leaders of the nation's advertising industry to help craft a message that would awaken the public consciousness. Amidst the triumph of mass consumerism during the early twentieth century, American advertisers had transformed the way goods were marketed to the public. As the frugality and thrift of pre-industrial consumer behavior gave way to the impulse and pleasure of modern shopping, the advertising industry became experts at targeting customers through emotionally-charged advertisements. Experts from various fields were called upon by the government to help mobilize American society for the war effort, and the Food Administration was no exception. In July of 1917 the J. Walter Thompson Company, headquartered in New York, was tapped by Hoover to serve as "advertising counsel" for the Food Administration. Though at the time the exact nature of the work was unclear, the company had already made explicit their objective to "make every piece of printed matter interesting, human, and attractive." The company's vice-president, Charles Raymond, came to the nation's capital to oversee the Food Administration's ad campaign. The services of the nation's

\footnotetext{
8 "Nutritionism" as a term was first introduced by scholars in the early twenty-first century to describe a phenomenon that had developed over the course of the twentieth century. It refers to how consumers, with the guidance and encouragement of scientists, advertisers, and the government, increasingly assess food based on its nutritional components. Thus, people have come to rely more on the opinions of experts and less on culture or tradition. With nutritional claims constantly changing, confusion and frustration lead many consumers to tune out. The result, according to many critics of the modern American food system, is a paradoxical situation where modern science has lead to a greater understanding of food from a biological perspective, yet the diet of the average American contributes to poor health. For more on this topic, see Michael Pollan's In Defense of Food: An Eater's Manifesto (New York: Penguin Books, 2008).
} 
most talented poster artists had already been secured, and talented ad copy writers prepared the material. The Food Administration quickly reached out to all of the nation's newspapers and magazines to secure their cooperation to help promote what was dubbed "the biggest advertising campaign in the history of America." Within a month, however, the advertising agency was able to formulate a more specific plan, and on the eve of the Food Bill's passage in early August, the company produced a detailed report on the proposed advertising campaign for the U.S. Food Administration. While acknowledging the success already achieved by the Food Administration in "arousing the American public to a consciousness of the need for personal effort in food conservation," the ad agency reported on how the current program might be enhanced, as well as pointed out potential weaknesses in the campaign that might be addressed. ${ }^{9}$

The report gave a detailed assessment of all forms of printed media that was to be employed. While the use of press notices was viewed as economical and able to reach a wide-ranging audience, it was criticized for not having the ability to connect directly with individuals on a personal level. In addition, the ephemeral nature of the news was a drawback, since the message of food conservation needed to remain within the public consciousness. Describing the news as more or less a form of entertainment, the report concluded that the use of press releases should be expected to do nothing more than generate a passive response and thus should be used as nothing more than an "accessory aid" to the propaganda program. Mediums such as posters, billboards,

9 J. Walter Thompson Company, "News Bulletin No. 54," July 2, 1917, Duke Online Collection; U.S. Food Administration, Press Release, July 9, 1917, Box 11, Folder 4, U.S. Food Administration Records, Hoover Institution, Stanford University; "Report of Proposed Advertising for Department of Food Administration Prepared by J. Walter Thompson Company," August 8, 1917, Box 44, Folder 14, U.S. Food Administration Records, Hoover Institution, Stanford University. 
and direct mail were also viewed critically. Posters could merely enhance an idea already conveyed, while direct mail, though more personal in nature, would be too costly and inefficient. With regard to the use of local organizations to arouse interest, once again the report viewed the potential impact as limited, both in terms of reach and durability.

The primary mode of printed publicity, according to the officials at J. Walter Thompson, was the use of advertisements in newspapers and magazines. They likened the work of the U.S. Food Administration to that of a commercial business trying to influence the behavior of potential customers. Press releases, posters, and other forms of media discussed above, according to the report, "would be the last that a progressive manufacturer would use to change the buying habits of the American people." The use of commercial-style ads would allow for the combination of vibrant display and information, which, if printed in the various papers and magazines, could potentially reach the average American five times a day. It was also believed that the use of ads would lend an air of prestige and sincerity, and that such advertised propaganda could "be made interesting without conveying the idea that the reader has been unwittingly 'sold;' for there is no deception involved in an open, honest, straightforward appeal."10

To supplement these ads, the report suggested that the Food Administration also periodically send out "official bulletins" of information, complete with the signature of Hoover, to be published in participating periodicals. In terms of style, it was advised that the majority of the space be a standard form, while the design and nature of decorative borders and opening statements be left to the discretion of each periodical. Such

10 Thompson report. 
authoritative messages had the potential of becoming a "national event, to be looked for and read almost as one's duty."11

The themes of duty and service would come to permeate much of the propaganda generated by the U.S. Food Administration, and the task of convincing the American people to voluntarily alter their eating habits was itself compared to a military operation. Described as "entrenched in their customary habits as though in a military operation," the public's resistance had to be met with "corresponding and sufficient forces." "What is needed," argued the report, "is enough heavy artillery to annihilate opposition to a raid." The Food Administration was advised to expect the message of food conservation to "encounter very great popular inertia." In essence, the food control program of the U.S. Food Administration was to fundamentally, if only temporarily, alter national customs. In order to overcome the great obstacle of breaking people of their established beliefs and habits concerning food consumption, Americans remaining at home would have to better appreciate the immediacy and meaning of the war itself. The authors of the report used the language of war to describe the current state of the American public. ${ }^{12}$

However, the Food Administration was also keen to avoid making their message too militarized. An effort was made to avoid certain phrases, such as "food control army," in describing the Food Administration and its voluntary members. Hoover

11 Thompson report.

12 Thompson report. 
believed that focusing too much on war war imagery and language might ultimately turn off the main target of their message, the American housewife. ${ }^{13}$

Upon the formal establishment of the Food Administration, a Public Information Division was created within the organization to deal specifically with the creation and distribution of propaganda. The department, also referred to as the Education Division, was headed by Ben Allen. Allen, a journalist and fellow Stanford alum, had worked closely with Hoover and the Commission for Relief in Belgium while he was with the Assoicated Press in England. Within this division were sections that dealt specifically with various avenues of publicity, including the news press, the motion picture and advertising industries, retail displays, and a number of different specialized publications, such as women's, farm, and religious journals. Each section had a designated leader, and it was expected that these leaders would consult and work closely with the various experts that had been placed on staff. In addition, a great deal of autonomy was given to state and local Food Administration representatives. Hoover did not want to "force publicity" from the top-down. The material that came from Washington was limited to that of "first importance," while additional efforts were to be handled by local officials. While the task of generating the propaganda was diffused, the ultimate release of information was tightly controlled from the top. To ensure a consistent message, and to make sure all information conformed to the latest policies, all final materials produced from the division were to pass first through Allen, and then on to Hoover's office for approval. It was also established that Allen would handle any and all personal interactions with the news press, and all incoming calls from the press were to be 13 Letter, Herbert Hoover to Ray Wilbur, undated, Box 7, Folder 11, U.S. Food Administration Records, Hoover Institution, Stanford University. 
forwarded to him. However, despite the level of control taken on by Hoover and his office, it was also stressed that Food Administration propaganda needed to portray the agency as an institution comprised of the nation as a whole, not a singular personality. The division was under strict orders to avoid the use of Hoover's name and likeness as much as possible. ${ }^{14}$

On the day the Food Control Act was signed into law by President Wilson, the Public Information Division presented the government's plan to present their message to the American people. Using the input from experts of various fields including home economics, nutrition, and public health, the agency aimed to cultivate among Americans a "new conception of national duty that will lead them to change their habits of living." In creating the blueprint for food conservation propaganda, there was a conscious effort made to tap into the collective psychology of the population, to show that the food situation is serious, to cultivate an interest in conserving food, and to instill the belief that restrained eating habits would help win the war. In order to reach as many Americans as possible, Food Administration propaganda utilized every form of media. The agency worked closely with the nation's newspapers, magazines, and journals. Editors for publications such as Today's Housewife, Woman's Home Companion, and the New York World joined the ranks of the Food Administration, ensuring that the government's message would find its way to the pages and columns of the nation's leading periodicals. It also displayed its message on posters and billboards, sponsored public lecture tours, and worked closely with the burgeoning motion picture industry. The

\footnotetext{
14 George Nash, The Life of Herbert Hoover: Master of Emergencies, (New York: W.W. Norton, 1996), 28; Herbert Hoover, Memorandum, August 15, 1917, Box 45, Folder 7, U.S. Food Administration Records, Hoover Institution, Stanford.
} 
Food Administration also called on the country's network of private institutions and organizations to spread the word. Churches, fraternal orders, patriotic societies, and labor unions were among the many groups that were utilized by the government to reach individual citizens at the local level. Special efforts were also made to cultivate open communication with hotels, restaurants, and other public eatings spaces, as well as food retailers, to ensure that they were also projecting the message of food conservation to their patrons. ${ }^{15}$

Much of the Food Administration's publicity was geared towards generating an emotional response that would lead to compliance with their program. At the heart of this message was the idea that the food conservation program was a vital part of the nation's overall war strategy. Thus, the language, and imagery, of war, was a central theme in Food Administration propaganda. it became essential to convey the idea to Americans that what they were eating in their homes became as important to the war's outcome as what the soldiers were doing in the battlefields of Europe. The goal of the Food Administration was to foster a spirit of collective sacrifice at home, and associate food conservation with patriotism.

Perhaps no other Food Administration official more clearly expressed the idea that practicing food conservation was an exercise in national service and the ultimate expression of patriotism than Dr. Vernon Kellogg, a Stanford biologist who had worked with Hoover in Europe on the Commission for Relief in Belgium. Kellogg joined the Food Administration staff as a nutrition expert and coordinator with Allied efforts. Writing in the Atlantic Monthly in November of 1917, Kellogg in very great detail presented to the

15 "Publicity Division of Food Conservation of the Food Administration," August 10, 1917; Box 11, Folder 5, USFA Record, Hoover Institution, Stanford University. 
American people the "food problem" that not only threatened the United States, but the entire world. Citing an exhaustive string of figures, Kellogg explained how and why the Allied nations faced such dramatic shortages, and how and why it was up to the United States to solve the problem. By the United States taking on the duty of feeding its Allies, food conservation had become a patriotic service. Thus, the ultimate outcome of the war depended on the American people and their level of patriotism. "We are patriots enough to stand up with the right music, to float the flag, and to yell when the soldiers go by," declares Kellogg, but "are we patriots enough to stand without flinching when our pockets and appetites are touched? We shall see." His words expressed the hope that the Food Administrations work would produce a psychological effect and inspire patriotism by making the war real for those on the home front. The conservation program, according to Kellogg, offered the opportunity for universal service in a great national endeavor. "Patriotism and food!" exclaimed Kellogg, "Winning a world war by eating corn and chicken instead of wheat and beef!" He went on to convey the hope that this endeavor might have consequences that lasted beyond the end of the war. "Incidentally," wrote Kellogg, "it may mean much fore for the years after the war; we may get the food-saving habit-and the habit of patriotism."16

The use of vivid, patriotic imagery to sell the idea of food conservation was an extremely important aspect of Food Administration propaganda. One way this was done was through the publication of hundreds of different posters which were distributed nationwide and prominently displayed in various public settings, including schools, government buildings, train depots, and retail outlets. The posters all relied on symbols

16 Vernon Kellog, "Patriotism and Food," Atlantic Monthly, November 1917, pp. 577-588; Vernon Kellogg and Alonzo Taylor, The Food Problem (New York: Macmillan Co., 1917), 210. 
and slogans to stir the emotions of the American public through a combination of patriotism and fear. Uncle Sam, the American flag, and Lady Liberty were commonly featured. In one example, Lady Liberty, draped in the stars and stripes, looks straight ahead with arms outstretched and asks the viewer to "Be Patriotic" by signing the food pledge card. Additionally, militaristic imagery such as the battlefield or the trench were often presented to associate more directly people's actions at home with the war being fought overseas. For example, one poster showed a colorful basket of fruits and vegetables imposed over an outline of American soldiers lined up for battle, with the caption, “Food is Ammunition - Don't waste it!" Women and children in particular, as major groups that made up the home front, were targeted by Food Administration posters, and the overall theme of the publicity material reflected such gendered, middleclass values as honor, duty, and efficiency. Posters were not only an effective way to elicit an emotional response from those remaining on the home front, they will also be used, as will be discussed in the following chapter, as an educational tool to show Americans how exactly they could follow the government's food conservation program. Scholars have also noted that many of the same themes and techniques used by the government during World War I to promote their food control agenda will be used again to promote government food rationing during the Second World War. ${ }^{17}$

One particular public venue that would play an important role in spreading the message of the Food Administration through vivid imagery was the motion picture theater. Although still in its infancy, the film industry was one the government hoped to

17 Tanfer Tunc, "Less Sugar, More Warships: Food as American Propaganda in the First Wold War," War in History, 19 (2012): 193-216; digital images of U.S. Food Administration posters can be found at the National Archives website, https://www.archives.gov/education/lessons/sowseeds/. 
work closely with to reach the American public. A section specializing in motion pictures was organized within the Educational Division and headed up by Arthur Friend, an executive with Famous Players-Lasky Corporation, a prominent motion picture company. By 1917, there were over eighteen thousand theaters throughout the country, and the medium was recognized as being particularly effective in generating an emotional response from its audience. In the days leading up to the passage of the Lever Bill, Friend, working with John Wylie of the Moving Picture World, reached out to leaders of the film industry with the hopes of establishing a relationship in the realm of wartime food conservation. In a letter addressed to the nation's leading manufacturers and distributers of moving pictures, the Food Administration sought to enlist the services of the film industry while also urging caution. The letter expressed an appreciation of the willingness of film makers and distributers to help the cause, but also stressed the importance of such efforts lining up with the message coming from the Food Administration. "Errors in messaging," warned the agency, "would result in confusion and wasted effort." As a result, the government asked that the industry hold off on releasing any film that attempted to address the issue of food conservation until "a plan of propaganda is worked out that is fundamentally sound in every particular." The Food Administration concluded the letter by stressing its willingness to consult and advise motion picture producers regarding content relative to food conservation. ${ }^{18}$

The government also reached out to the nation's film houses and motion picture theaters to request their participation in the program. Indicating the Food

\footnotetext{
18 Letter, John Wylie to Arthur Friend, August 8, 1917, Educational Division, 12HA-F13, Box 506, Record Group 4, National Archives, College Park; Letter, Arthur Friend to Manufacturers and Distributers of Moving Pictures, Educational Division, 12HA-F13, Box 506, Record Group 4, National Archives, College Park.
} 
Administration's plans to produce "an interesting series of motion pictures showing how 'Food Will Win the War,"' the government expressed a strong desire to have their work shown in every theater across the nation. Participating picture houses could consider themselves members of the Food Administration. Beyond the benefit of claiming membership in this government agency, the Food Administration stressed that other perks could result from cooperating. "You will not only be doing your country a helpful service," declared the government agency, "but you will win for your theater a higher respect in your immediate community." Additionally, a sense of gratification would result from the material contribution to "the greatest cause in our history." In response to their request, the Food Administration received a number of letters from motion picture exhibitors expressing their willingness to assist. Theater owners and managers from large cities and small towns alike wrote letters of thanks for being given the opportunity to serve. A number of them also proclaimed that the motion picture was the one medium that could reach the greatest number of Americans. One theater owner went further to suggest that the motion picture audience would also be receptive to the Food Administration message, noting that, in general, his audiences were "very enthusiastic" whenever news reports on the war were shown on the screen, especially when accompanied by patriotic imagery such as the American flag." 19

19 Letter, USFA to Motion Picture Exhibitors, September 7, 1917, Educational Division, 12HCA4, Box 505, Record Group 4, National Archives, College Park, MD; Letter, W.L Sheibley to Arthur Friend, September 28, 1917, Letter, Ernest Stewart to Friend, September 25, 1917, Letter H.L. Beach to Friend, October 2, 1917, Letter, A.J. Salter to Friend, October 3, 1917, Letter, F.V. Thompson to Friend, September 27, 1917, Letter, J.H. Pillis to USFA, September 25, 1917, Educational Division, 12HC-A4, Box 505, Record Group 4, National Archives, College Park, MD. 
In terms of involvement with the actual production of moving pictures, the Food Administration was active on a number of different levels, from reviewing, altering, and approving films from various private companies, to producing and distributing films and slides of their own. It was clear from the beginning that the government saw the potential impact this emerging industry could have on getting their message out to the American public. Hebert Hoover was contacted directly by an individual from Illinois who told of his plans to produce a motion picture that embraced subjects such as increasing the production of coal, the appeal to America's youth to join the armed forces, and the conservation of foods, all of which were to be "embodied in one huge dramatic picture." He told the Food Administrator's head of his intent to use, as a visual effect, a banquet scene set in a hotel, "at which Corn bread is used, instead of Wheat." Hoover responded with keen interest to the "plan for incorporating food propaganda" in the film, requesting a copy of the script and offering assistance if it "conform[ed] to our policy." In early August, before passage of the Lever Bill, the Motion Picture Division of the Food Administration was contacted by a member of the Vagabond Players, a small community theater out of Baltimore, Maryland. The troupe had produced, under the supervision of the Baltimore City Food Commission, what they dubbed a "food conservation movie," and had reached out to the government agency to gauge its interest in using the film as part of their propaganda campaign. Entitled Fighting at 
Home, the picture's story focused on one of the central themes of the Food Administration's message - that of food conservation as national service. ${ }^{20}$

The movie's plot centered on the tale of a young man, named Fred, who was denied the opportunity to join the military and fight overseas. Despite being rejected by the military for reasons beyond his control, Fred is initially labelled a "slacker" by many in his community. However, he is quickly inspired by the message of food conservation being pushed by the government, which declared that "the agricultural army at home is just as important as the actual army in the field." Thus, Fred finds a way to serve the nation's cause and fight the enemy by following and promoting the government's food control program. He initiates a number of food conservation measures in his community, including the organization of canning classes and lectures on food issues, the formation of a community food market, and the promotion of home gardens among his neighbors. The climax of the film comes when Fred is confronted by corrupt local politicians, whose food profiteering racket was being threatened by his actions to conserve food and cut prices. Though initially looking to "beat some sense" into the young patriot, the profiteers are shamed into a change of heart by Fred when he poses the following question: "The men, fighting in the trenches, are making the supreme sacrifice for their country. Shall we, who stay at home, sacrifice nothing?" In response, the men declare their intentions of becoming true patriots and following Fred's lead. Initially viewed with suspicion and scorn by community leaders due to his lack of military service, the young

20 Letter, Myron Fagan to Herbert Hoover, July 15, 1917; Letter, Hoover to Fagan, July 18, 1917, Educational Division, General Office, 12HA-F13, Box 494, Record Group \#4, National Archives, College Park, MD; Letter, Adele Nathan to Dr. Joseph Krauskopf, August 6, 1917, Educational Division, General Office, 12HA-F13, Box 506, Record Group \#4, National Archives, College Park, MD; Maxcy Robson Dickson, "The Food Administration," Agricultural History 16 (1942): 91-96. 
man eventually wins their respect and admiration for his conservation work. As a result, he is made an honorary officer in the government's "Food Army." Finally, to further heighten the emotional appeal of the film's message, the patriotic efforts of the film's protagonist win for him the girl he loves. ${ }^{21}$

Despite not being the product of a major film producer, the film's quality was good enough for nationwide release, declared the theater company representative. The movie had already received the approval of some noted industry experts, and two of the most popular film houses in Baltimore had agreed to show the moving picture. Arthur Friend, head of the Motion Picture Division in the Food Administration, expressed a strong interest in the project, and quickly made arrangements to view the picture in Washington. Overall, Friend found the movie "rather interesting," and felt that it had promise to become part of the agency's propaganda campaign. However, he also pointed out that some changes would have to be made in the film's captions if it were to be adopted by the Food Administration. First, in order to comply with the objective of the Food Administration's head that propaganda avoid as much as possible the use of his name or likeness, any mention of Herbert Hoover was to be removed. Stressing the institution over the individual, it was advised by Friend that the film increase the presence of the Food Administration itself by giving more screen time to its slogans and symbols throughout. Additions to the film's dialog were also made to further coordinate the movie's message with that of the government's. For example, during the film's final scene, the Food Administration adds the following proclamation issued by the

21 Letter, Adele Nathan to Dr. Joseph Krauskopf, August 6, 1917, Educational Division, General Office, 12HA-F13, Box 506, Record Group \#4, National Archives, College Park, MD; Letter, Hellen Kraus to Arthur Friend, August 20, 1917, Educational Division, General Office, 12HAF13, Box 506, Record Group \#4, National Archives, College Park, MD . 
government to the hero of the picture: "Fred, you have proved that you can be a patriot without wearing a uniform."22

Over the course of the next several weeks, the two parties engage in protracted negotiations as the theater company tried to ensure proper distribution and the Food Administration attempted to ensure that the proper revisions were made to the film's story. Finally, at the end of November the Food Administration contacted the Vagabond Players to express its interest in purchasing the film outright from the theater company. The government stressed its desire to close the deal quickly and essentially told the Players to name their price. Further, the agency stated that the purchase would include the transfer of all rights to the film, and any further changes to the movie's content would be done by the Food Administration. They planned to produce six copies of the picture and distribute it to theaters across the country. Finally, on December 7 , the purchase of the film was finalized, and the film was to be sent to Arthur Friend's offices in New York City so final revisions and duplications could be made. This, however, is the last known communication concerning Fighting at Home. It is not known whether the film was ever given its full release by the Food Administration. However, its story clearly reflects the desire on the part of the Food Administration to, not only portray the food

22 Letter, Adele Nathan to Dr. Joseph Krauskopf, August 6, 1917; Letter, USFA Motion Picture Bureau to Nathan, August 9, 1917; Internal Memo, Aurthur Friend to Dr. Ray Wilbur, August 17, 1917; Letter, Hellen Kraus to Friend, August 20, 1917, Educational Division, General Office, 12HA-F13, Box 506, Record Group \#4, National Archives, College Park, MD. 
conservation program as an opportunity for national service, but to further place such service on the same level as participation in the military. ${ }^{23}$

Another example of the Food Administration's work with the film industry involved a collaboration with more established members of the motion picture community. In August of 1917 representatives of Mr. and Mrs. Sidney Drew, a famous comedy act, contacted Arthur Friend to express their desire to show their newest film to Hoover. The duo claimed to have worked with the Food Administration's own Dr. Wilbur to compose the film's story, the result being that it contained "considerable food propaganda treated in a manner to send a message home to the American people." Entitled The Patriot, the moving picture was shown to Food Administration officials at a private screening on August 16 at the Savoy Theater in D.C., before its public release. Although the specific details of the film's plot are not known, it is clear that the government approved of its content, as it helped organize and promote screenings of the picture throughout the country in the summer and fall of 1917. In one example, the Food Administration contacted the society editor of the New York American, urging him to publicize a local meeting of household servants. The goal of the gathering was to equip the cooks and food handlers with the tools that would allow them to "do the real war service of carrying out the suggestions" being made by the Food Administration. The highlight of the meeting was to be the public premiere of The Patriot. Although the government did not own the film, it frequently instructed Drew on where to send the picture for screenings,

23 Letters, USFA to Helen Kraus, August 25, August 31, 1917, Letters, Kraus to Friend, September 1, September 4, September 30, November 24, 1917, Letter, USFA to Kraus, November 27, 1917, Letter, USFA to Friend, November 27, 1917, December 7, 1917, Educational Division, General Office, 12HA-F13, Box 506, Record Group \#4, National Archives, College Park, MD. 
and there's one example of Drew requesting permission from the Food Administration to show the film at a number of meetings. ${ }^{24}$

In another instance, the Knickerbocker Film Company of New York requested the approval of the Food Administration for a list of films with titles such as "A Bride With Brains," "Wasteful Winnie's Awakening," and "As Good as Wheat." These films, according to Knickerbocker, "treat[ed] the subject of Food Conservation in a practical way by giving the actual demonstrations and, at the same time, have human interest touches and events which might occur in any home in the United States." If films were produced to meet the policy of the Food Administration, they would receive an official approval. This process of obtaining the Food Administration's stamp of approval could become tedious and involve various rewrites and reshoots to an existing film. In an exchange with the Universal Film Manufacturing Company concerning a picture starring May Irwin, the Food Administration suggested extensive changes to make it conform to government regulations. The film had Miss Irwin making "freedom bread," but she clearly used four cups of wheat flour to one cup of cornmeal. The entire scene would have to be changed to show a greater proportion of the wheat substitute. Such interactions show how deeply involved the Food Administration was with the private film industry and how concerned it was with promoting a carefully crafted message. ${ }^{25}$

24 Telegram, Arthur James to Arthur Friend, August 15, 1917; Arthur Friend, Internal Memo, August 16, 1917; Letter, USFA to Society Editor, New York American, August 24, 1917; Telegram, Sydney Drew to Dwees Dilworth, August 30, 1917; Letter, Dilworth to Drew, August 31, 1917; Letters, USFA to Drew, October 24, 1917, December 13, 1917; Letter, USFA to Mr. J. Vestervelt, March 2, 1918, Educational Division, General Office, 12HA-F13, Box 506, Record Group \#4, National Archives, College Park, MD.

25 Letter, John L. Davis to Alice Allen, June 5, 1917; Letter, Alice Allen to Harry Levey, March 3 , 1918, Educational Division, General Office, 12HA-F13, Box 494, Record Group \#4, National Archives, College Park, MD. 
However, despite having limited involvement in the actual production of moving pictures early on, by the end of its first year the Food Administration had begun experimenting with making its own films. In August of 1918 the agency partnered with Arthur Friend's Laskey-Paramount Company to produce a cartoon relating to sugar consumption. Noting that it had previously only produced slides that were shown prior to feature films and that, in their own words, were "not altogether satisfactory," the Food Administration distributed this short animated film to a number of state food administrators as an experiment. It wanted these local officials to screen the movie and then provide feedback to the central office in D.C. on how it was received by the public. The Food Administration was also keen to explore the possible use of new film industry technologies to spread their message of conservation. Around the same time the agency was experimenting with producing their own films, Ray Wilbur was reporting on demonstrations he witnessed of equipment that synchronized film with sound by simultaneously using a phonograph and moving film projector. He further stated that both exhibitors he met with were anxious to make the technology available to the government for use in its propaganda campaigns. Wilbur apparently came away intrigued with its possibilities. "Since new things will be required if there is to be a very striking impression made upon the public," declared the Food Administration official, "this scheme is well worthy of careful consideration." Wilbur believed that the technology could be used to show various speeches by the likes of Hoover and President Wilson, which, when combined with "a number of actual, well-chosen war pictures, would make a very strong appeal." Though securing the use of the new synchronized pictures would cost a considerable amount, he suggested that the financial burden could be spread 
amongst all of the government agencies involved in generating propaganda, since they would all benefit from the technology. ${ }^{26}$

Motion picture houses, as well as other types of theaters, were also used by speakers who addressed audiences on the issues of food control and conservation. Although no formal public speaking division was ever created by the Food Administration, the agency worked closely with other organizations, both private and governmental, to arrange the use of speakers. To ensure that the message conveyed was one that adhered to the Food Administration's principles, it periodically published a bulletin which contained a broad collection of facts, figures, and slogans that speakers were encouraged to use in their public addresses. As early as July of 1917 , when the Food Control Bill was still being debated in Congress, speakers working on behalf of the government stood before audiences armed with a number of specific talking points concerning the food problem and the proposed solution. By October, the Food Administration had distributed over forty thousand pieces of literature to fifty-seven hundred speakers throughout the nation. The Home Conservation Section had conducted a complete survey of the nation, reaching out to the officers of a number of local organizations for a list of expert speakers in their respective communities. A registered list of over twelve thousand potential speakers was complied by the Food Administration. The government wanted speakers to stress the immediate causes and effects of food control at home, and the fact that the outcome of the war depended on a government-led conservation program. Speakers were also instructed to focus on the more fundamental aspects of the food problem and its solution. The proposed program General Office, 12HA-F13, Box 506, Record Group \#4, National Archives, College Park, MD; 
of voluntary cooperation in democratic America would be put up against the program of rations, decrees, and bread cards found in autocratic Germany. Quotes such as: "To fail in unity of purpose would be the undoing of America," and "To fail in self-control would be a betrayal of democracy," were included in the bulletins. ${ }^{27}$

Such points were stressed even more for speakers once food control legislation was passed and the Food Administration was officially organized. Speakers were instructed to stress food control both as an opportunity for ordinary citizens to serve, and as a major test for American democracy itself. A typical passage delivered to audiences was as follows:

Food Administration is an adventure in democracy staking the issues of war on volunteer effort. By self-control, not by decree; By cooperation, not by compulsion; To provision our associates in the war sufficiently by conducting our own households wisely.

Americans were told that the conflict went beyond the immediate boundaries of the current war. It was a battle of autocracy versus democracy, with "one system or the other commanding civilization in the next stage of the world." The government's call for food conservation, unlike its calls for military duty, was a form of service all Americans could partake in, and it was expected that all Americans, regardless of social or economic status, would partake. Attaining a unity of purpose was essential. "War will not tolerate slackness," stressed one talking point, "neither sloth for fighting nor extravagance of living." Wasteful consumption from the wealthy would promote class dissent and undermine the needed sense of unity. The goal was to unite all of society

27 Mullendore, History of the U.S. Food Administration, p. 91; "Speakers Division Report," October 1, 1917, Box 12, Folder 2, USFA Records, Hoover Institution, Stanford; "Minutes Conservation Committee," March 11, 1918, Box 10, Folder 5, USFA Records, Hoover Institution, Stanford; USFA, "Saving Subsistence: A Bulletin for Speakers," Government Printing Office, July 1, 1917, Box 12, Folder 2, USFA Records, Hoover Institution, Stanford. 
under the banner of thrift. Such "universal service" paved they way for "universal peace." Success in this undertaking was linked to the broader objectives of the nation's involvement in the war itself, as laid out by Wilson himself - "making the world safe for democracy." Further, if Americans could save enough food to defeat the German threat, it would prove that democracy was safe for the rest of the world. ${ }^{28}$

In addition to organizing its own speaking engagements, the Food Administration also worked closely with the Committee on Public Information to secure the services of the famous Four-Minute Men to deliver the message of food control to Americans. On at least three different occasions, the Food Administration provided to the Division of FourMinute Men a special bulletin for its twenty-five hundred speakers. In early July 1917, a full month before the Food Administration was officially organized, Hoover relied on existing Four-Minute Men, and they were instructed to "bring home the fundamental necessity of the personal service of each man, woman, and child" to follow the government's lead as it related to food behavior. The Food Administration was also very cautious to ensure that the correct tone was used by the Four-Minute Men. While it was important that speakers portray the food situation as a serious and important matter, they also had to keep the audience engaged and avoid creating a sense of hopelessness. Speakers were encouraged to make the audience laugh at least once. "Do this," proclaimed the director of the Four-Minute Men William Blair, "and you will be remembered all summer and it will be a pleasure to eat one-half of what has been customary - not a deprivation." The personal obligation to serve was stressed, while the

28 USFA, "An Adventure in Democracy: A Bulletin for Speakers," Bulletin No. 2, Government Printing Office, September 1917, Box 12, Folder 2, USFA Records, Hoover Institution, Stanford; USFA, "Solving the Problem," Speakers Bulletin No. 3, September 1917, Government Printing Office, Box 407, Folder 7, USFA Records, Hoover Institution, Stanford. 
actual role of the government was to be downplayed. It was up to each person to be their own "food controller," the Food Administration was merely pointing the way. The speakers were also encouraged to portray the food crisis as an opportunity for Americans to reform wasteful food behaviors. Four-Minute Men were instructed to deliver lines such as, "Now is the time to lay your double chin on the altar of liberty; you don't need it anyway."29

In addition to wanting to reach Americans with the message of food conservation as they traveled by bus or train, read the paper, or attended the moving picture house, the Food Administration also wanted its presence felt inside the kitchen. There was a strong belief shared by Hoover and his associates that in order for their plan to succeed, the food problem had to "be brought to each door step." One important way this was accomplished was through the implementation of a Home Card campaign. For those individuals who decided to participate, such a program not only served as a constant reminder of what was expected of them with respect to food choices, it also provided an opportunity for the government to more explicitly present to ordinary American citizens an opportunity to serve by actually becoming a "member" of the U.S. Food Administration. Perhaps more than any other aspect of the food conservation program, the Home Card campaign expressed how the war would fundamentally change how the government would come to influence how Americans ate.

The campaign was actually begun in the summer of 1917 , and remained part of the Food Administration's program for much of the war. The primary target of the Home

29 Committee on Public Information, Division of Four-Minute Men, "Food Conservation Week," July 8, 1917, Government Printing Office, Box 336, Folder 14, USFA Records, Hoover Institution, Stanford University. 
Card, and the food conservation program as a whole, was the American housewife. In June President Wilson pointed out that while Congress was still bickering over food control legislation, American women were growing anxious in waiting to do their part. The president advised them that the best way to help was by "enlisting in the service of the food administration and cheerfully accepting its direction and advice." Soon after taking control of the government agency, Hoover made a direct appeal to the women of America. The language of service and war imagery was present throughout the government's appeal to women. By registering for membership in the Food Administration women would be "entering directly into national service." While the country's young men risked their lives in the battlefields of Europe, those that remained at home could "fight by helping the fighter fight." 30

Hoover rather matter-of-factly declared that it was up to the housewives of the United States to feed the rest of the world and ensure victory for the United States and its allies. While the head of the Food Administration was quick to point out the difficulty of the task ahead, he also expressed a faith in the American public as a whole, and the American housewife in particular, that they would willingly do whatever was asked of them. The keys, according to Hoover, were not only informing the public of the current food crisis abroad, but also making them aware of the food problem at home. While across the Atlantic access to nutrition was severely limited, a practices of a relatively large portion American households had helped in earning "the deserved reputation of the most wasteful housekeeping in the world." Once again, the situation is portrayed as an opportunity, one in which the nation's women could "make our country a model of

\footnotetext{
30 USFA, Bulletin No. 1, "Food Administration Invites Every Woman to Register and Sign Pledge," June 17, 1917, Box 401, Folder 6, USFA Records, Hoover Institution, Stanford.
} 
economical management throughout the world." In addition, the language of war and service is used to compel action. Addressing American women directly, Hoover asserted that they "now face the immediate duty of taking up arms in your household." "The wolf is at the door of all the world," declared Hoover, and the outcome of the war itself was on the shoulders of the women of the nation. ${ }^{31}$

To organize the American women in "a great army," the Food Administration asked each of them to become an actual member of the government agency. This was described by Hoover as being "one of the most important factors in the Administration's plan." By becoming actual members of the Food Administration, citizens would become a more receptive audience, and a general feeling of cooperative support could be more easily cultivated. The tiny pledge cards, approximately the size of a modern business card, were distributed through various channels, including religious organizations, civic groups, and local food conservation boards. The registration campaign began on July 1st, but it wasn't until the autumn of 1917 that a major, nationwide drive for pledge card distribution was organized. The drive was to last for seven days, from October 27 to November 4, with the goal of distributing tens of millions of pledge cards to the American people. General guidance came from Washington, but implementation was to be handled at the state level. State Food Administrators oversaw the distribution, while subcommittees were formed at the local level to handle logistics. Making clear that they sought as members the individual in the home responsible for handling the food, the card read as follows: "I am glad to join the service of the food conservation for our

31 USFA, Bulletin No. 1, "Food Administration Invites Every Woman to Register and Sign Pledge," June 17, 1917, Box 401, Folder 6, USFA Records, Hoover Institution, Stanford; Herbert Hoover, "Mr. Hoover Asks the Help of American Housewives," undated, Box 490, Record Group \#4, National Archives. 
nation and I hereby accept membership in the United States Food Administration, pledging myself to carry out the directions and advice of the Food Administration in my home, insofar as my circumstances permit." The card also asked individuals to provide certain household details such as number of residents, the occupation of the breadwinner, and whether or not the house has a garden or employs a cook. ${ }^{32}$

There were no dues or fees required to become a member of the Food Administration, and those that joined and provided a mailing address would receive a Home Card of Instruction to hang in the kitchen. The card was double-sided, with one side providing a detailed explanation as to why Americans were being asked to sacrifice. It explains in detail the food crisis facing the Allied nations, as well as the reasons why the United States as a result has to send more of its food overseas. The flip side of the Home Card contains at the top the phrase: "What You Can Do to Help Win This War." It then went on to explain in detail what is expected of Americans with regard to consumption of specific foodstuffs, including wheat, beef, pork, dairy and sugar. ${ }^{33}$ In addition to the card that hung in the kitchen, Americans that signed on with the conservation program were also given a card that was to be hung in a window for public display. This particular aspect of the Home Card campaign was based on a practice in England, in which cards, bearing the phrase "This House Has Given A

32 Letter, Hoover to David Lawrence, August 3, 1917, Educational Division, General Office, 12HA-A11, Box 490, Record Group \#4, Records of the United States Food Administration, National Archives, College Park, MD; Pledge Card, Education Division, Illustrations and Plates, 12HC-A1, Box 501; USFA Memorandum, "Publicity Division of the Food Conservation Division of the Food Administation," August 10, 1917, Box 11, Folder 5, U.S. Food Administation Records, Hoover Institution; USFA Memorandum, August 23, 1917, Box 10 Folder 14, U.S. Food Administration Records, Hoover InstitutionUSFA, Bulletin No. 1, "Food Administration Invites Every Woman to Register and Sign Pledge," June 17, 1917, Box 401, Folder 6, USFA Records, Hoover Institution, Stanford.

33 these specific instructions will be the subject of the next chapter 
Soldier To Fight," were displayed in the windows of families of soldiers. In large, bold letters, the Food Administration window card advertised that the inhabitants were members of the agency and contained the official emblem of the government agency, which was composed of a United States shield surrounded by a wreath of wheat. ${ }^{34}$

In addition to the private home, the public eating spaces of America were offered the opportunity to sign a special pledge card. To be filled out by the manager of the hotel or restaurant, the signed card committed the space to observe the directives and regulations of the Food Administration. Each business was then provided an official placard that could be displayed as evidence of its membership. Though such an approach was certainly inspired by the belief that a great deal of compliance would be secured from progressive businesses that bought into the concept of national sacrifice and service, it is not unreasonable to think that there was a hope that even businesses more concerned with the bottom line would see compliance and the opportunity to publicize it as good business practice. The nation's movie theaters were also given the opportunity to become members of the Food Administration. Those theaters that signed and returned pledge cards were sent a framed certificate that they were expected to display in the lobby. ${ }^{35}$

\footnotetext{
34 United States Food Administration, Home card and window card, August 1917, \#23/2/749, Box 17, Folder 40, New York State College of Home Economics Records, Series IV, Rare and Manuscript Collections, Cornell University Library, Ithaca, NY; Letter, Hoover to Lawrence, August 3, 1917, Educational Division, General Office, 12HA-A11, Box 490, Record Group \#4 National Archives.

35 USFA, Public Eating Spaces Pledge Card, undated, Box 501, 12HC-A1, Educational Division, Illustrations and Plates, Record Group \#4, National Archives; Letter, USFA to State Food Administrators, September 1917, Box 501, 12HC-A1, Educational Division, Illustrations and Plates, Record Group \#4, National Archives.
} 
The Food Administration looked to public venues such as moving picture houses to also promote the pledge card drive among individuals. In September of 1917 the Washington office reached out to the state Administration representatives to encourage them to appeal to their local motion picture exhibitors. In much the same way they had made their general appeal for support earlier in the summer, the Food Administration sought the help from the industry in promoting the drive by presenting it as an opportunity to "demonstrate their loyalty, their patriotism, and their absolute commitment to the principles of democratic government." Further, they could prove the oft-made claim by the industry that the moving picture was the greatest power and force for good. In terms of specific plans for theaters, the Food Administration was to make available by the start of the drive on October 21 a collection of short newsreel clips from prominent studios such as Pathe and Universal. The clips showed events relating to the Food Administration, such as Congressional leaders voting for the Food Control Bill, the president signing the legislation into law, and Herbert Hoover leaving the White House. In addition, the agency had prepared two series of slides promoting the Pledge Card drive and food conservation in general that they expected the theaters to show before every feature. They were also asked to display official Food Administration posters, including the official "shield of service," the slogan, "Food Will Win the War," and the statement "Official pictures of the United States Food Administration are shown at this theater." It was expected that that both the membership certificates and the posters be displayed "conspicuously" in the lobbies and "present an attractive appearance," and 
were to remain there for the duration of the war. The hope was that such displays would serve as advertisements for the Administration's work in the film industry. ${ }^{36}$

The Four-Minute men were also once again utilized to deliver the message of food conservation and stress the importance of becoming members of the Food Administration. At the end of October the speakers were instructed to focus their talks on the food pledge drive and were once again provided a packet of information to guide their speeches. The goal of the speech according to Hoover was to inspire the nation to action and to "enlist as nearly as a possible one hundred percent of America's twentytwo million households in an army that will wholeheartedly support food conservation." While patriotic appeals for sacrifice were powerful and certainly a central theme to the agency's propaganda, the Four-Minute men were also encouraged to put a more positive positive spin on the Food Administration's program. First, they were told to point out that the goal of the government was not to deprive Americans of needed nutrients nor the basic pleasure of eating. Additionally, it was to be stressed that the program involved no forced coercion from the government. Americans, unlike the Europeans, were given the freedom to choose compliance. Further, speeches were to proclaim that the Food Administration was looking out for the nation's best interests, and the food control program not only offered an opportunity to serve the nation, but it also provided an opportunity for Americans to improve their lives. Audiences were told that if everyone joined in, the cost of food would go down. It was a chance to learn something new, "to change appetites, to cook differently, and thus feed your family better than before at less

36 Letter, USFA to State Food Administrators, September 1917, Letter, USFA to State Food Administrators, November 3, 1917, Letter, Illinois Federal Food Administration to the Moving Picture Theaters of Illinois, November 7, 1917, Box 501, 12HC-A1, Educational Division, Illustrations and Plates, Record Group \#4, National Archives. 
expense." Speakers were told to inform Americans that changing food habits was not just a war necessity, it was also a permanent necessity. ${ }^{37}$

In addition to the more practical arguments made above, the Four-Minute Men were also instructed to appeal very strongly to he audience's conscience. Not only would changing food behavior to conserve be the practical thing to do, it was also the moral thing to do. Speakers were to emphasize the need for the nation to get back to a time when the waste of foods was a sin. "Implanting this concept," proclaimed the instructions, "will eventually impact eating habits." The prospect of butter, a foodstuff that needed to be conserved, being used in cooking would become so unappealing that the palate of the American man would actually come to prefer meat prepared with the less scarce vegetable fats. Such transformations would not only result in a nationwide spiritual cleansing, but it would have the added bonus of pushing the country towards healthier eating habits. Speakers were also encouraged to avoid discussion of broad, underlying factors causing the food problem. The point was to make the crisis as personal as possible. Thus, it was important to focus on how the Food Administration's program not only provided an opportunity to prove one's patriotism, but could also lead to such things as a reduction in the cost of living and better overall personal health. ${ }^{38}$

To further strengthen the association between food conservation and wartime service, the Food Administration also began offering in the July of 1917 the opportunity

37 Committee on Public Information, Division of Four-Minute Men, Bulletin No. 18, "Food Pledge Week," October 29, 1917, Government Printing Office, Box 336, Folder 14, USFA Records, Hoover Institution, Stanford University.

38 Committee on Public Information, Division of Four-Minute Men, Bulletin No. 18, "Food Pledge Week," October 29, 1917, Government Printing Office, Box 336, Folder 14, USFA Records, Hoover Institution, Stanford University. 
for women to obtain an official Food Administration uniform. Just as those soldiers enlisted in the nation's military were expected to wear the official government-issued regalia as part of their service, the those willing to join the "great food army" being assembled on the home front were given the opportunity to obtain their own "attractive service costume." The leadership at the Food Administration called the women who chose to wear the uniform "a symbol of the Democracy and uniformity of purpose which inspires their service in the great Food Conservation campaign of the Government."39

There were two options available to women who wanted to acquire the uniform. For a dime, the Food Administration would send a pattern, complete with a size chart and general directions for cutting and sewing. The body was to be made of a plain blue material of the regulation shade, while the cap and button-on sleeves of white pique. They could also purchase a pair of embroidered insignias, which were to be applied only to the uniform's cap and the sleeve. The government was explicit in stating that the patches could not be used on other types of clothing or "any place but where designated." This option, claimed the Food Administration, allowed "thrifty women to make the service uniform at home in a short time and at little cost." However, many of the country's clothing manufacturers also produced the uniform, and so women could also purchase the costume "off-the-rack" at department stores across the nation. Upon its launch, the Food Administration worked hard to promote the pledge card and costume and market them much like the newest fashions and latest fads, while also imbuing it with the messages of national service and patriotic sacrifice. Images and

39 United States Food Administration Conservation Section, Press Release, July 11, 1917, Box 11, Folder 4, US Food Administration Records, Hoover Institution; United States Food Administration Conservation Section, Press Release, July 6, 1917, Box 11, Folder 5, US Food Administration Records, Hoover Institution. 
reports of pledge card signings and women in uniform found their way into various forms of Food Administration propaganda. The agency frequently took the opportunity to publicize examples of women from all ranks of American society buying into the conservation program, from minorities and the working class, to the nation's social and political elite. ${ }^{40}$

Within a few weeks of launching this massive campaign, Hoover's faith in the volunteer spirit of America's democratic society appeared to be validated. By the first week of August in 1917, he could claim that over one million signed pledge cards had been received in Washington, while "many thousands" of Food Administration uniforms had been purchased. A woman from Missouri wrote Hoover to inform him that the ladies of her county had "registered liberally" for the pledge card drive. The response had been so enthusiastic that they had composed a song which they hope would further "enthuse registration." Entitled "Woman's War Cry," the lyrics displayed that at least some of America's women had clearly associated their call to conservation with a military exercise:

We will rally 'round our boys and obey the nation's call, Shouting the battle cry of 'FREED 'EM!'

Eat more cornbread and less potatoes boil, Shouting the battle cry of 'FREED 'EM!'

Our boys must have meat but we can do without, Helping Hoover to feed 'em, If they the Kaiser beat we will have to get about,

40 United States Food Administration Conservation Section, Press Release, July 11, 1917, Box 11, Folder 4, US Food Administration Records, Hoover Institution; United States Food Administration Conservation Section, Press Release, July 6, 1917, Box 11, Folder 5, US Food Administration Records, Hoover Institution; United States Food Administration, Photograph, "Woman Modeling Uniform of USFA," Box 13, Folder 13, U.S. Food Administration Records, Hoover Institution; USFA, Press Release, July 14, 1917, Box 11, Folder 4, USFA Records Hoover Institution; USFA Food Conservation Section, Press Release. July 7,1917, Box 11, Folder 5, USFA Records, Hoover Institution. 
Doing our bit to help feed 'em

In addition, Hoover could point to actual numbers that suggested that Americans had already begun conserving food. He also claimed that he was receiving "splended cooperation" from the nation's leading hotel and restaurant men, while various private organizations, including religious, fraternal, and patriotic groups, were "marching behind the food banner." In addition to continuing the intensive publicity and pledge card campaigns, the Food Administration also had devised plans to foster the creation of "special, private 'food organizations"' that could operate at the state and local level and coordinate with official state and federal Food Administration officials. ${ }^{42}$

According to Hoover, these early successes were due largely to the fact that Americans had been convinced that their sacrifice was key in determining the outcome of the war, while at the same time being assured that this sacrifice did not mean discomfort. By the time the Lever Bill had become law, Hoover felt confident enough to declare that "the necessity of intelligent conservation and substitution" had permeated the consciousness of the American people. However, evidence was also mounting that suggested Americans were not as receptive to the government's program of food conservation as had been initially anticipated. Throughout the second half of 1917 the offices of the Food Administration were flooded with letters from citizens that took objection to the food conservation program for one reason or another. Additionally, the

41 Letter, Miss H. Trice to USFA, July 30, 1917, Box 490, 12HA-A11, Educational Division, General Office, Record Group \#4, Records of the USFA, National Archives.

42 Letter, Hoover to Lawrence, August 3, 1917, 12HA-A11, Box 490, RG \#4, National Archives. Hoover cites statistics on garbage collections in the nation's largest cities to support his claim of food conservation. 
agency itself took great pains to actively go out and gather as much information as it could regarding how the government's message was being received by the public.

Despite Hoover's positive outlook on the overall success of the Food Administration campaign, the actual numbers showed that they were falling short of their own expectations. In the wake of the major pledge card drive held at the end of October, official returns showed that pledge card goals were reached in only thirteen of forty-eight states, while the agency was two million short of their overall nationwide goal. The Public Speakers Division, which had organized over one hundred events in the final ten days of September, received a report from the field on October 1st that attendance was poor. Word coming from state and local officials was also at times discouraging. Officials in Washington were told by a representative in Philadelphia that the pledge card was "hated apparently by everybody," with local organizations complaining that they could not give them away. State officials also expressed reservations about the Food Administration uniforms, which was primarily based on concerns over affordability. The fear was that those that could not spare the money to purchase the uniform would be made to feel like they were not full-fledged members and thus less likely to go along with the campaign. ${ }^{43}$

By October of 1917 some media outlets were already writing about Hoover's "Food Control Failure." Writing in The Forum, noted food expert Alfred McCann

43 USFA, "Record of Home Card Returns," November, 15, 1917, Box 10, Folder 15, USFA Reocrds, Hoover Institution, Stanford; USFA, "Speakers Division Report," October 1, 1917, Box 12, Folder 2, USFA Reocrds, Hoover Institution, Stanford; USFA Home Conservation Division, "Report on Trip to Philadelphia," March 23, 1918, \#23/2/749, Box 17, Folder 52, NY State College of Home Economics Collection, Cornell University; Ray Wilbur, memorandum, "Report on Meeting of Sixteen State Representatives," July 20, 1917, Box 11, Folder 10, USFA Records, Hoover Institution, Stanford. 
presented a frank criticism of both the Food Administration and Herbert Hoover himself. Proclaiming that the agency was "destined to leave the world no better than it found it," McCann portrayed the Food Administration as an unnecessary expansion of government bureaucracy that had done nothing to stop the practices of hoarding and profiteering that contributed to ever-rising food prices. McCann also called into question the credentials of the agency's leader, claiming that "an efficient department store manager would have done the job" as head of the Commission for Relief in Belgium "with precisely the same results." The Food Administration at this point was only two months old, but McCann was already proclaiming that the nation's "faith in Hooverism as a miracle-working religion is already on the decline." 44

These developments reflected the overall ambivalence towards the war felt by many Americans. The fact that the nation was not universally behind the decision to declare war on Germany and enter the conflict is well-documented. Thus, it is not surprising to find that the public as a whole failed to fully buy into the program presented by the Food Administration. Such resistance can partly be explained by the growing fears of a central authority becoming a threat to individual liberty. These fears were aired both by concerned citizens and the political opposition to the Food Control Act detailed earlier. Historians have traced this stance against intrusive federal authority back to the rural post-Civil War South as southern farmer fought against government policies to modernize farming techniques. There was also a socioeconomic dimension to this resistance. Working class Americans believed the food control program was unfairly harsh, given that their economic situation already limited their food options.

44 Alfred W. McCann, “The Hoover Food-Control Failure," Forum, Oct. 1917, 381-390. 
Again, this reflected a broader strain in the war resistance that viewed the entire conflict as a "Rich Man's War, and a Poor Man's Fight." Recent scholarship has found that, even in the rural South, a region noted for its martial tradition, resistance to the war and military desertion was fairly widespread. 45

In the fall of 1917 the Food Administration examined some of the negative feedback it had received from the public since its inception. Based on a study of letters sent from Americans to Hoover and his agency, it was found that criticisms fell under one or more of twenty-three different categories. People felt that they were being asked to commit to a program that they did not fully understand, and the expectations that were understood were unrealistic. There existed among many a deep suspicion of government motives. Many Americans objected to what they felt was "blind obedience to the government." "Fear" and "confusion" were two words that commonly appeared in letters to the Food Administration throughout the summer and fall of 1917. A number of letters expressed the concern that the food conservation program was merely a first step in a process that would eventually involve government confiscation of food from private homes. According to them, the pledge card drive was a way for the government to compile a list of names and addresses of future targets. The National American Woman Suffrage Association wrote to Hoover's office and said that among the many objections they had noticed locally in New York was the fear that card signees would be required to send food away from their homes regardless of their needs. The Committee

45 For a detailed look at resistance to government agricultural policies, see Clair Strom's Making Catfish Bait out of Government Boys: The Fight Against Cattle Ticks and the Transformation of the Yeoman South (UGA Press, 2009); for a look at resistance to the First World War in the South, see Jeanette Keith's Rich Man's War, Poor Man's Fight: Race, Class and Power in the Rural South During World War I (UNC Press, 2004). 
on Public Information even informed the Food Administration of a report from a local CPI women's committee in Missouri in which the existence of a widespread fear that the pledge card campaign was part of a secret program to "take people out of their homes and send them to France and various other places." The lack of specificity in what exactly was expected of each American caused a great deal of frustration among the public. For some, the wording of the pledge itself was a problem. The final line that tried to limit an individual's sacrifice to what his or her circumstances could permit provided an open door for many to opt out of the program altogether. ${ }^{46}$

As early as July, a concerned citizen brought to Hoover's attention a report from New Jersey which noted widespread complaints from local women in response to the pledge card drive. According to those surveyed by the newspaper, most women felt that current food prices were already forcing them to cut back on food consumption. Rather than waste time asking citizens to conserve, they argued that the government should focus its efforts on curbing practices from whole-sellers and retailers that were driving up prices. "Let the government stop the destruction of things to eat," asserted one woman, "and we would sight these pledge cards with better grace." Another concerned citizen wrote that the women of his neighborhood had destroyed their cards, refusing, as he said, "to jump into something blind-folded as it were." A woman writing from Massachusetts called the pledge card idea "impractical and foolish." Since the

\footnotetext{
46 USFA, Memorandum, "How the People of the Country Criticize the Policies of the Food Administration," September 14, 1917, Box 11, Folder 10, USFA Records, Hoover Institution, Stanford; letter, A.H. Naftager to USFA, June 21, 1917, Box 11, Folder 10, USFA Records, Hoover Institution, Stanford; Letter, Mrs. M.F. Gabard to USFA, July 11, 1917, Box 11, Folder 10, USFA Records, Hoover Institution, Stanford; Letter, National American Woman Suffrage Association to USFA, August 7, 1917, Box 11, Folder 10, USFA Records, Hoover Institution, Stanford; Letter, Committee on Public Information to USFA, July 14, 1917, Box 11, Folder 10, USFA Records, Hoover Institution, Stanford.
} 
government relied on voluntary compliance and lacked any real enforcement powers, she argued that it would be easy for insincere Americans to simply sign the card and "still continue to go on doing just as they have been doing." There was even one example of a woman who had signed the pledge and joined the ranks of the Food Administration requesting to have her membership cancelled. After considering the requests being made by the government, she felt that she was not equipped financially to comply. "I live as cheap as any one can," asserted the Virginia woman, "let those with ability do the work." 47

Economic issues were certainly a common theme expressed in many of the correspondences from the public. While the food crisis certainly intensified existing class tensions within American society, it is also apparent that one of the unintended consequences of the Food Administration campaign was the creation of new stresses for those living within the lower segments of the socioeconomic ladder. Even before before the United States officially entered the conflict, the rising cost of living had caused hardship for millions of Americans. As discussed in the previous chapter, war caused prices to rise even higher, and a number of American cities had already experienced food riots. At the end of June, a reverend from Maine wrote to Hoover, expressing the view that current the current food program essentially punished poor citizens while those entities responsible for driving up food prices were being left untouched. He asserted that citizens would not heed government calls to serve as long

47 Clipping, from Newark Sunday Call, July 15, 1917, attached to letter, from S.A. Rush to Herbert Hoover, July 16, 1917, Box 490, 12HA-A11, Educational Division, General Office, Record Group \#4, Records of the USFA, National Archives; Letter, Mr. H.E. Clasady to USFA, August 3, 1917, Box 11, Folder 10, USFA Records, Hoover Institution, Stanford; Letter, Mary Aiken to USFA, July 30, 1917, Box 11, Folder 10, USFA Records, Hoover Institution, Stanford. 
as this perceived dynamic existed. Patriotism would only be stimulated, according to the religious leader, when the government solved the food problems at home. Calling the food pledge drive "simply absurd and a great waste of time and money," a man writing from the nation's capital complained that it was nearly impossible for poor Americans to purchase enough food to avoid going hungry. Those Americans already struggling to avoid hunger on a meager diet of staples were often frustrated, and sometimes outright offended, by government requests that asked them purchase more expensive substitutes for wheat and meat such as cornmeal, fish, and fresh fruits and vegetables. According to a woman in Florida, the poor were being asked to sacrifice more than the wealthy. "Women of the working class have been skimping [sic] and saving and actually underfeeding our families for months because our incomes would not buy sufficient food," wrote Kate O'Hare, "and all the while the food speculators were piling up their millions." For many in the working class, it did not seem fair that the government asked them to not only give up their young men to fight overseas, but to also deprive their families at home, while large corporate interests seemingly made record profits. ${ }^{48}$

While economic issues might have had a larger impact on the public's objections to the Food Administration's conservation program than its leadership had anticipated, they were aware of the potential problems it might cause. From the beginning, some of the Food Administration's propaganda focused specifically on the nation's wealthiest segments in an attempt to ensure that they would participate as well. In a speech given

48 USFA, Memorandum, "How the People of the Country Criticize the Policies of the Food Administration," September 14, 1917, Box 11, Folder 10, USFA Records, Hoover Institution, Stanford; Letter, Rev. W.G. Beasley to Hoover, June 28, 1917, Box 7, Folder 13, USFA Records, Hoover Institution, Stanford; Letter abstract, H.B. Bradford to Hoover, July 13, 1917, Box 7, Folder 13, USFA Records, Hoover Institution, Stanford; Letter, Kate O'Hare to USFA, undated, Box 11, Folder 10, USFA Records, Hoover Institution, Stanford. 
before the Smithsonian Institution, Hoover addressed the issue of class and its impact on food conservation. On the issue of food prices, he warned of even higher prices in the future if measures are not taken now to conserve food for the Allies. And while Hoover was speaking of the entire nation, rich and poor, when he stressed the unique opportunity for national service the food conservation program provided, he also took the opportunity to single out certain segments of the wealthier class. "We have had growing in this country," declared the Food Administration head, "a class of the population given over to more or less idleness and a great deal of extravagance." This, according to Hoover, had contributed at least in part to the growing class tensions. By following the government's conservation measures, America's idle rich could "demonstrate its fidelity to the national cause and its willingness to share its full portion of the national burden."49

When it came to responding to the various questions and criticisms coming from ordinary Americans regarding the cost of food, the Food Administration created a form letter that in great detail pointed out the causes of price increases, the best solution, and the ultimate outcome of this solution. Rather than greedy food producers and middlemen, the cost of food was going up primarily because extra money was being paid to farmers to increase output despite labor shortages. In addition, various transportation and distribution issues, both at home and abroad, were making more difficult to get foodstuffs to market. The letter also pointed out that despite the recent inflation in prices at home, they were not as bad as what nations such as England and Germany had experienced. The best solution to this problem was for sacrifice at home.

\footnotetext{
49 Herbert Hoover, speech transcript, "The World's Food Shortage," August 28, 1917, Washington, D.C., Box 74, Folder 1, USFA Records, Hoover Institution, Stanford.
} 
"We must set aside habits of method and habits of taste," declared the Food Administration, "forego all luxury and indulgence." The result of such sacrifice would not only ensure victory and make the "world safe for democracy," it would also help save democracy at home. In making its kitchens less wasteful and more efficient, America's democratic society would be "saved from its former sins of extravagance and waste."50

In an attempt to ensure that members of the upper class bought into the government's message of voluntary rationing, the Food Administration sent Dr. Alonzo Taylor out during the summer of 1917 on a number of speaking engagements with the nation's wealthy. In a similar fashion to the publicity geared towards the general public, Taylor stressed to the audience the dangerous situation facing our allies. Facing both mental and physical stresses, the populations of England and France were "tottering and staggering" near the edge of defeat. To avoid such a disaster, the Food Administration official declared that a more intense and thorough participation by the American public in the spirit of the struggle. In other words, more Americans needed to follow Food Administration conservation measures. For Taylor, it was up to the nation's wealthy to lead the charge. Citing his personal, first-hand experience living and working in the war zones of western Europe, he was convinced that the upper classes had a special responsibility to "serve as an example to our poorer classes." Thus, he strongly urged those attending, many of which he considered close friends, to "adopt a different public and private attitude toward the war." ${ }^{.51}$

\footnotetext{
50 USFA, "Suggestions for Form Letters on Price Questions," undated, Box 49, Folder 10, USFA Records, Hoover Institution, Stanford.

${ }^{51}$ Alonzo Taylor, memorandum, undated, Box 43, Folder 6, USFA Records, Hoover Institution, Stanford.
} 
In the wake of these meetings, a resolution was passed and publicly issued by a collection of upper class societies in which the country's wealthier citizens asserted its commitment to follow the guidelines put forth by the Food Administration. Echoing much of what Taylor had discussed in his talks, the resolution stressed the importance of having the upper class serve as an example to the rest of the population, particularly within a system that relied on the voluntary cooperation of the people. "The standard of living is in large part determined by the classes of means," declared the statement, "where standard of living is certain to be imitated by all classes of our population." It urged sacrifice from all segments of American society and declared that the burden must be borne by each class, not just in accordance with mere numbers, but also in proportion to their abilities and responsibilities. In other words, those with the means to do so, should sacrifice more than the average citizen. The resolution concluded by urging all well-to-do Americans "in every way to stand as an example in patriotic service and saving."52

In order to convince Americans of all backgrounds that the wealthy had bought in and that burden of conservation was not left to the rest of the country, the Food Administration was quick to publicize expressions of compliance such as the one above, as well as when those words were put into action. The government distributed a number of photographs with accompanying captions for publication in newspapers and magazines throughout the country, showing how the rich and powerful were doing their bit. The focus of much of this type of publicity was on the matriarchs of these influential families. One such photo, entitled "Woman of Wealth Demonstrates the Drying of

52 unattributed, Resolution, undated, Box 43, Folder 6, USFA Records, Hoover Institution, Stanford. 
Foods," shows Mrs. Oliver Harriman, a "wealthy New York society woman," operating a large food dehydration machine. The accompanying text also noted that Mrs. Harriman had made the extra effort to establish a food research laboratory in her home in order that she might help in the further preservation of food. Another example showed a Mrs. Vanderlip, the wife of a "well-known" New York banker, donning the uniform of the Food Administration while conducting conservation work. The caption noted Mrs. Vanderlip had gone so far as to install a complete system of food conservation in the kitchen of her summer home. However, the Food Administration was not above using its propaganda to shame upper-class Americans to action. One example of such a tactic can be found in a cartoon published by the agency for the nation's newspapers. Entitled, "Forgotten Guests at Our Table," the cartoon shows a gluttonous American heedlessly stuffing his face while reading the newspaper. Seemingly oblivious to his surroundings, the man pays no attention to the paper's headline begging Americans to save food, nor does he seem concerned about the Allied and American soldiers and starving European adults and children that are also seated at his table. Here was a vivid and powerful condemnation of the waste and extravagance referenced by Hoover above. 53

However, if the government wanted to steer the wealthy households of the nation towards food conservation, they needed to also target those individuals most responsible for putting food on the plates. The purchase, storage, and preparation of

53 USFA, photograph, "Woman of Wealth Demonstrates the Drying of Foods," undated, Box 406, Folder 11, USFA Records, Hoover Institution, Stanford; USFA, photograph, untitled, undated, Box 419, Folder 1; USFA, cartoon, "Forgotten Guests at Our Table," undated, Educational Division, Illustrations and Plates, 12HC-A1, Box 501, Record Group 4, National Archives, College Park, MD. 
food was largely handled by servants. Thus, the Food Administration in July of 1917 organized a special division that would focus on the domestic workers of wealthy American families. "The conspicuous waste in the kitchen of the millionaires," declared a government press release, "will stop as soon as the domestic employed by them learn that the food conservation movement is one of patriotism and dire necessity for the country." Chosen to head up the initiative was Miss Florence Wardwell, a "member of one of New York's oldest and most conservative families." Wardwell had made a name for herself with her "efficient" work as a member of the Belgian Relief Committee. The plan was to visit many of the notable summer homes and resorts along the eastern seaboard, where Food Administration experts would instruct gathered domestic servants in "methods of food saving via entertainments, lectures, pictures, and other attractive means." On Long Island, a meeting at the Garden Theater was attended by nearly twelve hundred servants who listened to speakers and watched the film The Patriot. By making such a publicized effort to impact the food consumption of the rich, the government was attempting to address the concerns that the directives of the Food Administration unfairly target the poor and working classes. "The woman who does her cooking and the woman who employs but one or two servants," proclaimed the release, "can now feel comforted that she is not carrying all of the war-food burden." 54

While this initial look into Food Administration criticism was in many ways cursory, the agency spent the rest of 1917 trying to find out why the government's food conservation campaign was falling short. The federal office reached out to all state and

54 USFA, press release, July 10, 1917, Box 11, Folder 4, USFA Records, Hoover Institution, Stanford; USFA, "Report of Meetings Held for Domestic Servants in Northeast," undated, Box 13, Folder 17, USFA Records, Hoover Institution, Stanford. 
local Food Administration representatives, asking them to report on reasons given by people who refused to sign the pledge cards. One thousand of the responses were then selected and a detailed report was composed for officials in Washington in January of 1918. The report found that widespread opposition to the Food Administration and its campaign generally fell into six categories: (1) those that were not fully convinced the need for food conservation was urgent, (2) those that were fearful bad faith on the part of the government, (3) those that found the conservation measures interfered with their religious, political, or economic views, (4) those that lacked confidence in Hoover, (5) those with personal issues, in this case typically nutritional, that hampered cooperation, and (6) those within the poorer classes that believed the campaign was against their interests. In surveying the public, it was apparent that a widespread fear existed among the public that the voluntary, indirect nature of the current campaign was just a first step towards more direct government control over the food supply. The report also found that open opposition to the Food Administration was fairly widespread across the country. While dissent appeared to be most prominent in the states of Wisconsin and Ohio, only fourteen states nationwide reported little to no opposition. ${ }^{55}$

In general, the report's authors asserted that Americans failed to grasp the nature and dimensions of, not only the food crisis, but the war as a whole. There was an overall sense of ignorance and apathy when it came to the assessment of the public's war effort. The author went so far as to suggest that such evidence signaled an undercurrent of unrest and indicated that all of American society was failing to pull together. As it related to the food issue in particular, it was found that the public could 55 USFA, internal report, "Where the Food Campaign Fails to Get Across," January 28, 1918, Box 11, Folder 10, USFA Records, Hoover Institution, Stanford. 
not conceive of the food supply as a quantifiable figure. Not surprisingly, much of the criticism came from American women. Many, particularly those of the middle- and lowerworking-classes believed that they were conserving well before the Food Administration asked them to. Their economic realities had forced them to do so. The report indicated that Food Administration propaganda was itself at least partly to blame. With much of the focus of the publicity on the American housewife, a great portion of the population was being left out. As a result, too much pressure was being placed on the nation's women. 56

The end of 1917 found the Food Administration at a bit of a crossroads. Despite the grand efforts of the Food Administration, along with the help of various local and state organizations as well as private companies, Hoover and his agency still faced a public that had failed to sufficiently unify behind the militarized, patriotic message of food conservation as national service. As its own research had shown, Americans came away from the various publicity campaigns and pledge drives continuing to hold serious reservations about a government program that was asking them to voluntarily alter their food behaviors in the name of fighting a war. In the wake of these poor initial returns, Hoover actually considered making a move away from voluntary cooperation and towards a program of required rationing, something that the Food Control Act had given him the power to do. However, still holding on to the belief that an inspired and enlightened American public would prove democracy's worth, he ultimately decided to continue with the program of indirect food control. The following chapter will examine how exactly the government responded to these shortcomings. Rather than focusing

56 USFA, internal report, "Where the Food Campaign Fails to Get Across," January 28, 1918, Box 11, Folder 10, USFA Records, Hoover Institution, Stanford. 
primarily on the "why" of food control, the Administration's propaganda beginning in 1918 began to emphasize more the "how." With the help of experts in the emerging fields of nutritional science and home economics, the Food Administration initiated various programs that instructed Americans on how they could best follow the guidelines set forth by the government. The results of this change in course not only encouraged greater compliance, it also had longer term implications for American food culture. 


\section{Chapter 3 - “Promoting 'Individual Reconstruction’ by Selling the Science of Eating"}

While awakening the consciousness of the American people was a central theme to Food Administration propaganda, it was not the only one. Once the public was awakened to the presence of a food problem and made aware of their obligation to aid in solving that problem, messages that focused on topics of patriotism and self-sacrifice lost their impact. The objective of the Food Administration went beyond convincing people to merely acknowledge the appeals for conservation and perhaps periodically consume a "meatless" or "wheatless" meal. The goal of the Food Administration involved a fundamental shift in how people lived their lives. "In other words," claimed high-ranking agency official and noted food expert Dr. Alonzo Taylor, "the entire internal life of the individual of every class is reconstructed on the basis of essential war needs and of the relation of all these factors in life to the carrying on of military operations." An important factor in this process was the education of the American public. The Food Administration not only took great pains to explain why people were being asked to sacrifice, but they also inundated the population with the latest scientific knowledge to show that such sacrifices were perfectly healthy. This meant that the government relied heavily on the aid of experts from such fields as economics, geography, the biological sciences, and, most importantly, the emerging discipline known as nutrition to craft a large portion of their propaganda. It also meant cultivating partnerships with existing institutions tasked with enhancing the collective intellect of the nation, such as the nation's schools and libraries. "The policy of the Food Administration," declared its leader Herbert Hoover, "is built upon the widest publicity of facts...the educational forces of the country will aid incalculably in translating this policy into history." Wherever 
Americans went during the war, they were likely introduced to new dietary concepts such as the calorie, proteins, or vitamins. The impact of such a development would not only cause Americans to reconsider their wartime behavior, but also very likely contributed to the modern development in American food culture where the science behind foods took on increasing importance in determining how one should eat. ${ }^{1}$

Recent scholarship has focused on the influence science has had on the shaping of modern American food culture. Harvey Levenstein has explored how scientific advances at the end of the nineteenth century gave rise to a completely new conception of food, one that emphasized nutritional value over taste or cultural importance. Helen Veit, in her study of the rise of modern food culture, argues that a great deal of the Food Administration's authority arose from this revolution in the science of food. By breaking down food to its chemical foundations, eating could be approached from a more rational or pragmatic place. The discovery and popularization of nutritional concepts such as the calorie and vitamin transformed food, argues Veit, into a variable that could be utilized "in a kind of cultural algebra" by social scientists and policy experts. If the public could learn to approach eating by considering a food's component nutrients, they would be more prone to substitute one food for another if they had a similar nutritional profile. Such developments, according to Veit, would have a lasting impact on American food culture. Wartime government propaganda that touted the nutritional similarities between legumes (a food Americans were encouraged to eat) and meat (a food Americans were

1 USFA, "Conference of Educational Directors at Washington, 2/28-3/1, 1918," March 1, 1918, USFA Records, Hoover Institution, Box 48, Folder 3. 
encouraged to conserve), reinforced the idea that food choices based on science was more valuable than those guided by culture or tradition. ${ }^{2}$

The focus of this chapter is an exploration of how exactly the Food Administration used its propaganda machinery to educate the American public on the "whys" and "hows" of is conservation program. It will examine how the agency relied heavily on the input from scientific experts in fields such as nutrition, as well as the country's educational institutions, to craft and then present its message to the American people. It will argue that by attempting to suppress the psychological or cultural forces that had largely shaped prewar food behaviors of most Americans, while simultaneously promoting the physiological or scientific factors in dietary choices, the Food Administration played a major role in shaping modern food culture in the United States. For the first time Americans on a large scale would be asked to consider the nutritional content of food in assessing its value. This is an approach to eating that has only increased over time.

One big challenge in achieving "individual reconstruction" of the population was overcoming traditional American food behaviors and tastes. Part of the Food Administration's propaganda thus sought to convince Americans, at least in part, to fundamentally change their attitude towards food. As a result of the war, the agency proclaimed that the value of food had come to take on a new meaning. According to a Food Administration release, food choices before the war had largely been based on

\footnotetext{
2 Harvey A. Levenstein, Revolution at the Table: The Transformation of the American Diet (Berkeley: University of California Press, 2003), 86-99; Helen Veit, Modern Food, Moral Food: Self-Control, Science, and the Rise of Modern American Eating in the Early Twentieth Century (Chapel Hill: UNC Press, 2013), 1-57; for a general overview of the development of modern food systems, see Amy Bentley (ed), A Cultural History of Food, vol. 6 (New York: Berg Press, 2012).
} 
taste, with little consideration for quantities, or the kind of foods best suited for particular needs. The agency had made it their responsibility to provide Americans with the practical knowledge that would allow them to figure out how they could solve the food problem. An example of this can be seen with how the government approached the consumption of one of the staples of the American diet. From the start, the Food Administration had targeted wheat as a primary foodstuff that needed to be conserved in order that it could be shipped overseas. With substitution rather than outright restriction the major focus of the government's propaganda, non-wheat grains such as barley were promoted as a viable stand-in. In June of 1917 a discouraging report was released that suggested Americans were not keen to follow such a guideline. An experiment, sponsored by the Food Administration, was conducted at a laboratory in New York to determine the viability of barley's use in the "victory bread" being promoted by the agency. The French-Pancoast labs examined breads with various levels of wheat substitutes and found that as little as five percent barley produced a texture, color, and flavor "unsatisfactory to the taste of well-fed Americans."3

In addition to changing long-standing food traditions, the Food Administration also found itself at times dealing with attitudes that had been created by the war itself. One example of this had to do with Americans' increasingly negative views towards anything associated with Germany, its people and culture. This included foods commonly perceived as "German," such as the hamburger and sauerkraut. While attempts were made to re-brand these foods by given them more patriotic, American

3 USFA, "Food in War and Peace," undated press release, USFA Records, Hoover Institution, Box 49, Folder 11; "Americans Won't Eat Barley War Bread," newspaper clipping, June 10, 1917, from Records of the US Food Administration, Record Group 4, National Archives, 12HAA11, Box 490. 
names like "liberty steak" and "freedom cabbage," there were also calls to boycott the foods entirely. Such actions, especially abstaining from sauerkraut consumption, went against Food Administration guidelines, which promoted the use of vegetables, both fresh and preserved. "Men and women in their patriotic zeal," commented Food Administration official and home economics expert Martha Van Rensselaer, "have been spreading a strong propaganda to discourage the use of a valuable foodstuff." To deal with the issue, state representatives of the Food Administration were encouraged to stress two important points concerning the food. First, that the dish's origins were more closely associated with the Dutch than the Germans, and second, that sauerkraut was a valuable food that added to the various ways cabbage could be used in meals. "No matter by what name it may be known," stressed the Food Administration, "sauerkraut is a valuable food and its use should not be curtailed as a result of over-zealous and illadvised patriotism." The campaign against this misplaced patriotism continued with pamphlets that included detailed recipes for making sauerkraut, as well as suggested meals that would compliment the dish. ${ }^{4}$

Another important obstacle that had to be overcome was convincing Americans that the changes in food behavior they were being asked to adopt were not going to have negative consequences on their overall health. In order to achieve this goal, the Food Administration relied heavily on the input from experts in such subjects as biology, chemistry, physiology, and the emerging field of nutritional science. The intent was to generate propaganda that would encourage Americans, for the first time, to "know

\footnotetext{
4 Martha Van Rensselaer to State Directors of Home Conservation, June 29, 1918, New York State College of Home Economics Records, Series IV, U.S. Food Administration Records; Rare and Manuscripts Collections, Cornell University Library, \#23/2/749, Box 17.
} 
something about food from a scientific perspective." Housed largely within the Office of Home Economics at the Food Administration, these experts were tasked with "formulating and translating the scientific and economic data into workable terms for the classes of people for whom it is intended." At times, Hoover would utilize the assistance of outside scientific authorities to strike at long-held perceptions. With his encouragement, National Geographic Magazine published an article that discussed recent research that challenged long-held views on the proper diet, namely the idea that consuming large quantities of meat was essential for providing energy and nutrients for hard work. Highlighting the potential problem things like tastes, culture, and habit pose to the success of food control, and ultimately the war itself, the article cited recent findings by scientists that found the peasant diet of southern Italians, comprised mainly of beans, olive oil, and vegetables, did not in any way compromise their health or ability to work. The article's author concluded that Americans should set aside their desire for meat and consume more vegetables, knowing that doing so would not result in any nutritional deficiency. The Food Administration also utilized the popular press to answer more general questions ordinary Americans might have about food conservation. Immediately after the passage of the Food Control Act in August of 1917, the Woman's Home Companion published an article prepared by the Food Administration entitled "What Must I Do?" The article provided readers (likely housewives) with tips on how to provide their families with a nutritionally-sound diet without going against the government's conservation guidelines. Additionally, the article addressed and explained 
other topics ranging from the dangers of hoarding food to the true meaning of food economy. 5

However, this type of propaganda mostly emanated directly from the offices of the Food Administration itself, often dealing with a particular topic or food. Throughout the war, the American public was bombarded with hundreds, perhaps thousands, of different types of printed material, with the goal of educating them about both the science of food and how to apply this knowledge in the selection and preparation of meals. Americans were presented with newspaper and magazine articles that introduced such fundamental nutritional concepts as the calorie, proteins, fats, and carbohydrates. Pamphlets containing detailed nutritional information about specific foods like corn or potatoes, along with accompanying recipes were constantly being distributed, as were bulletins that contained detailed answers to dozens of frequently asked questions about food, the science behind it, and its relation to the current war conditions.

One prominent example of this approach dealt with the government's attempts to change the public's perception regarding wheat. As has already been noted, wheat was perhaps the most important food in America's program to provide nourishment to its allies overseas. The Food Administration made a point to stress the various reasons why wheat had been so central to the conservation campaign, citing everything from its

5 USFA, "Food in War and Peace," undated press release, USFA Records, Hoover Institution, Box 49, Folder 11; USFA, "Outline for memo on the organization and scope of food conservation as the work of the Office of Home Economics," undated, USFA Records, Hoover Institution, Box 7, Folder 11; David Fairchild, "Forming New Fashions in Food: The Bearing of Taste on One of Our Great Food Economies, the Dried Vegetable, Which is Developing Into a Big War Industry," National Geographic Magazine, April 1918, No. 4, 356-369; Hoover to Gilbert Grosvenor, July 25, 1918, Records of the US Food Administration, Record Group 4, National Archives, 12HAA11, Box 490; USFA, "What Must I Do?" Woman's Home Companion, September 1917, p.5. 
ease of transport compared to other grains to, ironically, its compatibility with the traditional food culture and tastes of the Allies. To be successful, however, the agency realized that it had to address the "special psychological problems involved in the general problem of wheat conservation." To that end the Food Administration convened a committee of experts from various fields of the nutritional and biological sciences, including the likes of Vernon Kellogg, Alonzo Taylor, and Raymond Wilbur. The panel concluded that reducing the consumption of wheat and replacing it with other cereals such as rye, barley, oats, and corn would result in no negative health consequences. They went on to state that any impact from the reduction of wheat in the diet would be more psychological than physiological. In a speech entitled "Wheat Not Necessary," given in Washington, DC in March of 1918, Dr. Taylor stressed the need to abandon traditional tastes and take a more scientific approach to eating. Rather than an indispensable food, he characterized wheat as "an article of luxury." From a scientific perspective, wheat possessed no nutritional advantage over other grains or cereals, and its desirability was merely the result of taste, and the desire for comfort and convenience. Any expert that objected to such a view was, according to Taylor, "either a crank or a slacker." Finally, the above information was collected, along with additional material on the subject, and presented to the American people in the form of bulletin in May of 1918. Such actions clearly show the Food Administration's committing to using science in order educate Americans and ultimately shape their food behavior. ${ }^{6}$

6 USFA, "Why We Must Send Wheat," Bulletin Number 14, Washington, DC: Government Printing Office, from New York State College of Home Economics Records, Series IV, U.S. Food Administration Records; Rare and Manuscripts Collections, Cornell University Library, \#23/2/749, Box 17; USFA, internal memo for Vernon Kellogg, undated, USFA Records, Hoover Institution, Box 68, Folder 16; Alonzo Taylor, "Wheat Not Necessary," March 18, 1918, transcript,USFA Records, Hoover Institution, Box 44, Folder 1. 
In order to house, curate, and organize the myriad of such material produced by both the government and private parties, the Food Administration established its own Home Economics Library. The library was to serve as a centralized resource for all matters relating to food control and set to "aid American women in solving their housekeeping problems." The library housed a collection of tested and approved "economy recipes," all of the government bulletins relating to food control published both by the Food Administration and the Department of Agriculture, food conservation posters, and a large selection of popular and scientific works on topics such as dietetics and home economics. The government also worked to make such information more accessible at the local level. In September of 1917 the agency announced a plan to connect with the nation's public libraries. It requested that in each state, Food Administration representatives choose a qualified librarian to serve as a Library Publicity Director. They were then expected to solicit cooperation from all of the libraries in their respective states and monitor their activities. The Food Administration itself also opened up a direct line of communication with the public libraries through the distribution of a monthly bulletin entitled "Food News Notes for Public Libraries." In the first edition of the bulletin, Hoover expressed his desire to have all libraries establish a "Food Conservation Section." Such designated areas were to prominently display books, magazines, pamphlets, and all of the other types of printed materials that related to the food problem. The Food Administration head also encouraged libraries to arrange periodic talks for adults, as well as story hours for children, that would present the topic of conservation in an appropriate way. Hoover also suggested presenting graphic exhibitions that focused on a particular food-related topic, as well as organizing a 
bulletin board that would prominently display the latest information available from the government. He stressed the importance of changing the collection each month in order to maintain public interest and assured the libraries that specific and detailed directions along these lines would be provided by the Food Administration in subsequent bulletins. $^{7}$

The Food Administration not only attempted to accomplish this goal through the use of printed material that might reach the men and women at the home front, it also presented its propaganda in various public settings beyond the public library that were frequented by ordinary Americans. As already noted, the movie theater was an important tool that was used to present the emotional aspects of Food Administration propaganda. Private citizens in contact with the Food Administration also noted the value of the moving picture as an educational tool. "The movie screen is the one best medium to get in touch with the actual consumers," noted film producer Frank Fox. A concerned housewife wrote directly to Hoover, suggesting the reason the Food Administration had failed to achieve total success in getting Americans to "Hooverize" was due to a lack of knowledge. ${ }^{8}$ The reason for that, according to May Campbell, was that the printed materials failed to reach all Americans. She urged the government to present the preparation of approved dishes on the movie screen. Having a Food

\footnotetext{
7 USFA Food Conservation Section, Press Release, July 11, 1917, USFA Records, Hoover Institution, Box 11, Folder 4; USFA, "Food News Notes for Public Libraries," October 1917, Volume 1, Number 1, Washington, DC: Government Printing Office, from USFA Records, Hoover Institution, Box 49, Folder 8; USFA, "Food News Notes for Public Libraries," June 1918, Volume 1, Number 9, Washington, DC: Government Printing Office, from USFA Records, Hoover Institution, Box 49, Folder 8.

8 "Hooverize" was a term that was used to describe food behavior that adhered to Food Administration guidelines. Americans that "Hooverized" were ones that cut back on overall food consumption, eliminated wasteful food choices, and substituted foods that were exported for ones more readily available at home.
} 
Administration expert show the audience when and how ingredients should be used would give women the knowledge and confidence needed to buy into the agency's campaign. However, while the agency was quick to use the motion picture to awake the consciousness of the public, when it came to presenting particular educational information, it was much more cautious. Fearing the distribution of "grave errors" that could possibly undermine the overall food control campaign, the Food Administration urged the motion picture industry to be patient while the "many sides of the matter be given the most careful consideration and a plan of propaganda is worked out that is fundamentally sound in every particular."9

As noted in the previous chapter, the government was keen to ensure that films addressing the subject of food conservation depicted scenes and presented information that conformed to the agency's guidelines. When Food Administration officials were presented with moving pictures from private studios that did not line up with its messaging, it was not above demanding changes. If the studio wanted its film to receive the Administration's "stamp of approval," it would comply. In terms of materials made explicitly by the agency for moving picture houses, it was primarily limited to glass slides that were to be displayed daily between screenings of films. Agency officials were wellaware of the limitations of this approach. The head of the Moving Pictures Section, Arthur Friend, discouraged the use of too much content in the slides. According to him, a movie audience would not be willing to sit and read such content. While these slides contained some educational material, such as a line or two on suitable substitutes for

9 Frank Fox to H.A. Wheeler, September 25, 1917,USFA Records, Record Group 4, National Archives, 12HA-F13, Box 506; May Campbell to Hoover, February 21, 1918, USFA Records, Record Group 4, National Archives, 12HA-F13, Box 501; J. Wylie to Arthur Friend, August 8, 1918, USFA Records, Record Group 4, National Archives, 12HA-F13, Box 506. 
foods such as meat and wheat, the Food Administration apparently was never able to produce the type of instructional films that were suggested by the likes of Ms. Campbell. The closest the government appeared to get was the production of an educational cartoon film on the subject of sugar produced exclusively for the Food Administration by the Lasky-Paramount Company. Noting that the use of educational slides had been "not altogether satisfactory," agency officials sent out the film to a small number of films as an experiment. State Food Administration Educational Directors were to solicit feedback from viewers and theater owners and report back to the Washington office. It is not known whether the government took this approach any further. Given that this exchanged occurred near the end of the conflict, it is likely they ran out of time to pursue it fully, but it still shows the government's interest in educating the public using this relatively new medium. ${ }^{10}$

Another arena where the Food Administration was much more successful in educating the public on appropriate food behavior via visual demonstrations were the various state and county fairs, conventions and expositions, as well as a number of patriotic food shows, that were held throughout the country during the conflict. Such events allowed much more easily the presentation of "practical exhibits," which were viewed as very valuable in the campaign to change food behavior; and unlike initiatives such as the home card campaign, exhibits and demonstrations were intended to reach men as well as women. "Exhibits do a lot to convert women," proclaimed Food

10 Arthur Friend to Movie Theater Operators, October 4, 1917, USFA Records, Record Group 4, National Archives, 12HA-F13, Box 506; Friend to Ben Allen, October 6, 1917, USFA Records, Record Group 4, National Archives, 12HA-F13, Box 506; USFA Educational Division to H.E. Babcock, August 9, 1918, USFA Records, Record Group 4, National Archives, 12HA-F13, Box 506. 
Administration publicity expert Ben Allen, "and they are very much more valuable in the conversion of men, because men of course have not taken the time to read all the propaganda and this will catch the eye."11

Headed up primarily by the agency's Home Economics Division, the public demonstrations and displays organized by the Food Administration at these events were the clearest example of how the government presented educational information from the nutritional and domestic sciences in an attempt to reshape the food behavior of Americans. During the spring and summer of 1917, well before the agency had even been formally established by Congress, Hoover had begun communications with the American Association of Fairs and Expositions, a group which represented the country's fifty largest fairs and expositions. In July, a formal partnership between the government and the industry group was announced. The Food Administration intended on the state fairs to serve as "great food economy training camps," demonstrating the various methods of conservation to millions of Americans. However, the status of the agency was still up in the air as state and county fair season approached at the end of the summer. Without the resources necessary to formulate and execute a full-fledged plan, Hoover was only able to provide the events' organizers with some general guidelines. Most of the suggestions centered on the need to conserve wheat and the use of other substitute grains. Hoover discouraged the use of the term "war bread" to describe loafs using wheat substitutes and suggested terms such as "liberty" or "victory" in its place. The Food Administration also strongly urged the use of graphs, charts, and figures to illustrate points such as the amount of bread currently wasted in America. One particular

11 USFA, "Conference of Educational Directors at Washington, 2/28-3/1, 1918," March 1, 1918, USFA Records, Hoover Institution, Box 48, Folder 3. 
graphic exhibit suggested involved displaying a pile of sacks of flour to illustrate the amount of wheat that could be sent overseas if each person cut back a small amount. He also suggested the organization of baking contests that employed to use of grains such as corn in place of wheat. The purpose was to make clear, through the use of science and statistics, to each and every individual that small changes in their behavior could have a large impact. ${ }^{12}$

By the end of 1917, the Food Administration had produced a pamphlet entitled "Graphic Exhibits on Food Conservation at Fairs and Expositions," which provided extensive and detailed instructions for any group or organization that wanted to visually promote the government's message of food economy. Suggested topics to focus on included the saving of wheat and meats, the efficient use of fats, and the demonstration of food preservation methods. The pamphlet went into great detail to provide tips on constructing the displays, including images and photographs. For example, the Food Administration suggested five different features for a "Save the Wheat Section." The first involved the use of posters and visual displays to answer such common questions as "Why should we send the wheat abroad?" and "How can the actions of one make a difference?" The agency also strongly urged the demonstration of the making of "victory bread," with an emphasis placed on proper measuring and mixing. In addition, they stressed that recipe cards for the foods on display be distributed to the attendees. It was made known that each and every recipe presented by Food Administration would be

12 Ray Speer to Hoover, May 21, 1917, USFA Records, Record Group 4, National Archives, 12HA-A11, Box 490; Speer to Hoover, June 11, 1917, USFA Records, Record Group 4, National Archives, 12HA-A11, Box 490; USFA Food Conservation Section, Press Release, July 5, 1917, USFA Records, Hoover Institution, Box 11, Folder 5; Hoover to Speer, July 26, 1917, USFA Records, Record Group 4, National Archives, 12HA-A11, Box 490. 
tested in its own labs under the direction of trained experts. It was also suggested that a lunch counter selling the foods being promoted be set up on site. The government stressed the importance of having all those working the booths wear the Food Administration uniform, and noted the significance of making the lunch counter clean and attractive, as well as the foods being of the highest quality. The pamphlet even included a list of suggested slogans that were to be used throughout. Examples included "'We can not preserve Freedom unless we conserve food," and "Emergency Bread: It's good to eat, And it saves the wheat." The government wanted those visiting such exhibits to come away with the impression that food behavior it was being asked to adopt was easy to attain, good for health, and of service to the country. ${ }^{13}$

By all accounts it appears as if a large number of the thousands of fairs and expos held throughout the nation during the war presented at least some form of the information provided by the Food Administration. In addition, groups in a number of major cities organized expositions that dealt specifically with the topic. One such "patriotic food show" was held in Chicago during the spring of 1918. Its organization reflected the overall approach taken by the Food Administration in distributing its propaganda. An attendee noted that the purpose of the show was clearly to promote government food conservation, and the Food Administration had provided a good deal of guidance in its set up. A "food specialist" oversaw the exhibit and ensured each booth conformed to Food Administration guidelines. However, the event was organized by the State Council of Defense and managed in part by local prominent businessmen. It was

13 USFA, pamphlet, "Graphic Exhibits on Food Conservation at Fairs and Expositions," November 1917, Washington, DC: Government Printing Office, from USFA Records, Hoover Institution, Box 11, Folder 19; USFA, "Conference of Educational Directors at Washington, 2/28-3/1, 1918," March 1, 1918, USFA Records, Hoover Institution, Box 48, Folder 3. 
funded not by the government but by selling booth space to commercial outfits. In addition to paying for the space, each business had to agree to allow its exhibit to be carefully censored. It was noted that there were a few instances where the "extravagant claims of the exhibitor were caught up and stopped." The show was noted for its easyto-follow layout, which was divided into five main sections, covering proteins, fats, sugar, produce, and starches. A demonstration space ran down the middle of each section, with the food prepared offered as samples to those in attendance. The recipes for the foods being prepared were collected and made available in a Patriotic Cook Book. Overall, however, the show left an underwhelming impression for at least a few. One observer noted that the show's "food specialist" wished a greater effort had been made to "show the exhibitors how they could make their displays educational and at the same time good advertising for themselves."14

There's little doubt that leaders in Washington learned about the shortcomings of the event in Chicago. Immediately after the Patriotic Food Show, the federal office of the Food Administration reached out to its state officials and requested that each adopt a "more definite program and creation of an organization" to deal more directly with the organization and presentation of exhibits. Reiterating the potential value of such events by expressing the belief that attendees rarely encountered such information in other settings, the agency pointed out that the headquarters had compiled information that could be helpful in organizing exhibits. The Food Administration also eventually took pains to address one of the largest potential drawbacks of using large amounts of food,

\footnotetext{
14 Mary Swain Routzahn, "The Chicago Patriotic Food Show: A Brief Review of its Main Features," April 1918, New York: Department of Surveys and Exhibits, Russell Sage Foundation.
} 
both those being requested to conserve in displays and those being urged to consume as substitutes. It was clear that by suggesting the use of things like bags of wheat in displays to encourage economy, or by holding cooking demonstrations for appropriate foods that might not be eaten, the Food Administration opened itself up to the potential of bad publicity or public backlash. Relaying this concern to local officials, the federal office referenced a recent exhibit plan it had received that called for the presentation of fifteen tables of cooked food. Noting that such a plan was "not in line with the program of food conservation," leaders in Washington urged state directors of home conservation to come up with more desirable ways to demonstrate and dispose of such items. Some suggestions provided included the establishment of a conservation cafeteria booth, where the public could purchase foods made via demonstration. This is similar to the "lunch counter" idea proposed in the pamphlet mentioned above. They also suggested giving such foods to local charities, or auctioning it off with the proceeds going to a group like the Red Cross. ${ }^{15}$

Food control propaganda not only targeted the hearts and minds of the American housewife and other adults occupying the home front, it also sought to shape the outlook of the nation's youth. In his recent examination of American government propaganda during World War I, Robert Gross shows how children became critical targets. Linking the wartime campaigns to recent advances in mass marketing techniques, Gross argues that children's lives were politicized during the war in a way

15 USFA to Federal Food Administrators, April 13, 1918, USFA Records, Hoover Institution, Box 49, Folder 11; USFA Home Conservation Division to State Directors of Home Conservation, June 14, 1918, NYS College of Home Economics Records, Series IV, USFA Records, Cornell University Libraries, \#23/2/749, Box 17; USFA Home Conservation Division to State Directors of Home Conservation, June 27, 1918, NYS College of Home Economics Records, Series IV, USFA Records, Cornell University Libraries, \#23/2/749, Box 17. 
that had never been seen before. In no other interaction is the Food Administration's emphasis on providing useful information in their propaganda clearer than it was with the nation's schools. Hoover and his associates realized from the start that if the government was going to succeed in educating the public on issues relating to the wartime food problem, they were going to have to get their message into American schools. Additionally, the program was seen to have the potential to shape thoughts and behavior well beyond the immediate needs of the war. Discussing the matter with President Wilson, Hoover stated:

We feel that, by taking advantage of the war emotion, we here have an opportunity of introducing intelligibly into the minds of children, not only fundamental data on nutrition, but also of being able to probably secure its permanent inclusion in school curricula, and, therefore, feel that it is a matter of more than ordinary propaganda importance. ${ }^{16}$

Further, the food control propaganda geared towards schools was once again viewed as an opportunity to impart additional messages regarding the virtues of democracy and the responsibilities of citizenship in the "cooperative society in which they live." The classroom was viewed as a training ground for proper citizenship, where personal responsibility could be stimulated within every child and a deeper appreciation of the meaning and aims of American democracy could be learned. ${ }^{17}$

16 Robert N. Gross, “'Lick a Stamp, Lick the Kaiser:' Sensing the Federal Government in Children's Lives During World War I," Journal of Social History 46 (2013): 971-988; Herbert Hoover to Woodrow Wilson, August 21, 1917, , USFA Records, Hoover Institution, Box 5, Folder 7.

17 Robert N. Gross, "'Lick a Stamp, Lick the Kaiser,"' Journal of Social History (2013), 971-988; Hoover to Wilson, August 21, 1917, Hoover Institution, Box 5, Folder 7; A.N. Farmer and Janet Rankin, Food Problems: To Illustrate the Meaning of Food Waste and What May Be Accomplished by Economy and Intelligent Substitution (New York: Ginn and Company, 1918), 1-3; U.S. Food Administration, untitled pamphlet (partial), 1917, Washington, D.C.: Government Printing Office, Hoover Institution, Box 47, Folder 5. 
Thus, in the summer of 1917 the Food Administration announced the creation of the Educational Department within the Food Conservation Section. Even though Congress had yet to pass legislation officially creating the Food Administration, the provisional agency did what it could to cultivate a relationship with the public school system. Using this existing machinery, government looked to educate not just the nation's students in effective food conservation but the entire population as well. In addition to being a place for classroom instruction, the government also identified schools as important community centers. The Food Administration noted that schools had already been used as a meeting space for the broader community to engage in various patriotic services, such as the making of surgical dressings that could be sent to treat wounded soldiers overseas. ${ }^{18}$

Efforts to engage with American schools began at the end of June. Hoover contacted Charles Richard Van Hise, noted progressive academic and president of the University of Wisconsin, and requested that he attend the upcoming gathering of the National Education Association in Portland, Oregon. The plan was for Van Hise to act as an unofficial representative of Hoover, both speaking to the general session on the first day of the conference and holding a series of smaller information sessions throughout the week. The objective was to introduce the food problem to the nation's educators and make them aware of their importance in spreading the government's message regarding food control. ${ }^{19}$

\footnotetext{
18 U.S. Food Administration Food Conservation Section, press release, July 13, 1917, Hoover Institution, Records of the United States Food Administration, Box 11, Folder 4; .

19 Charles Van Hise to R.L. Wilbur, June 23, 1917, Hoover Institution, Records of the United States Food Administration, Box 46, Folder 9.
} 
As the summer of 1917 came to an end, and American schoolchildren looked to return to the classroom, the president, at the urging of Hoover, reached out to the officers of the nation's public schools and encouraged them to adopt the upcoming program and associated materials that would be presented to them by the Food Administration. After speaking generally about the unique challenges the global conflict presented to the American people and their institutions, the president stressed that, in addition to its soldiers overseas, the civilians at home needed to learn the "lessons of war." Schools were urged to increase the time and attention devoted to instruction on such issues. Several weeks later, the Food Administration issued a leaflet directed specifically at the nation's teachers. Identifying them as a "powerful factor in the life of your country," the government stressed the unique position teachers were in to reach the nation's children with the message of food conservation. However, teachers were not only being asked to enlighten their students, they were being called on to awaken the entire country. Hoover expressed his confidence that the teachers understood the food problem and appreciated the importance of transmitting "exact information" to the population in order for the Food Administration to gain their support. Where other facets of food control propaganda might have fallen short, the agency asserted that teachers could serve as the missing link by reaching the mothers of their students. Educators were asked to "enlist every family in the army of the Food Administration and make them effective agents in winning the war."20

20 Woodrow Wilson to School Officers, August 23, 1917, Hoover Institution, Box 47, Folder 5; U.S. Food Administration, leaflet, "Young America's Part," Washington, D.C.: Government Printing Office, 1918, Hoover Institution, Box 49, Folder 11; Herbert Hoover to the Teachers of America, September 1, 1918, Hoover Institution, Box 47, Folder 7. 
The government also suggested some very basic guidelines for teachers to consider before a full-fledged program could be presented. Just as in the propaganda directed towards the general public, educators were encouraged to stress the concepts of conservation, substitution, avoidance of waste. It was believed that one particular venue where these ideas could be effectively presented to schoolchildren was the cafeteria. Teachers were instructed to closely monitor students during lunch. If students were eating a meal provided by the school, the staff was told to engage with them on how the food provided was linked to conservation efforts. If a child brought his own lunch, teachers were to urge children to be efficient by bringing no more than would be eaten. Working on the assumption that nearly every student had a brother, father, cousin, or uncle serving overseas, the government also stressed the importance of making personal connections by pointing out that food behavior at home impacted the diet of American soldiers overseas. ${ }^{21}$

By August the Food Administration had begun to organize "definite courses of instruction for all of the schools, primary as well as secondary, on nutrition and food economics generally." Hoover had initiated a joint project with the Bureau of Education in the preparation and distribution of a series of textbooks for students at all levels of the nation's public school system. The Food Administration at this early stage also strongly considered the preparation of a specific course on the subject of food conservation for the nation's public schools. While the other materials could be handled by the teachers, it was suggested that this particular course be administered by trained experts within the field. In addition, the Food Administration in the summer of 1917 worked closely with

21 USFA, "Young America's Part," 1918, Hoover Institution, Box 49, Folder 11. 
the U.S. Commission of Education on a separate program that emphasized various aspects of wartime behavior. Entitled "Lessons in Community and National Life," the government looked to highlight the immediate need of food conservation while also featuring its production and distribution during wartime. ${ }^{22}$

Once again, however, the aim of the propaganda went beyond the lessons of wartime food behavior. This particular set of materials also stressed broader issues of service and citizen responsibility. According to the Food Administration, the lessons were to "teach children the privileges and obligations of the democratic form of government under which they live." Speaking specifically about the program, Hoover highlighted the importance of stressing the interdependent nature of modern American society. Widespread cooperation on the home front was essential for victory and teaching about the rights and obligations of citizens was an important part of the process. Additionally, the goal was to not only make schoolchildren aware of the various changes that were to result from the war, but to also emphasize the need for continued efficiency once the conflict concluded. All of these actions were necessary, not just to secure victory, but also "in order to meet the fierce industrial competition that will follow the making of peace." The "Lessons" were issued monthly during the school year by the Bureau of Education. The program was intended for students ranging from the fourth to twelfth grades, and the materials were modified accordingly to fit into three distinct groupings. While the government urged schools to set aside instruction time to present

22 Herbert Hoover to Woodrow Wilson, August 21, 1917, Hoover Institution; USFA, "Minutes of Meeting of Advisory Committee on Home Economics," August 17, 1917, Hoover Institution, Box 10, Folder 5; USFA Public Information Division, Press Release Number 284, October 2, 1917, Box 47, Folder 5, Hoover Institution. 
the "Lessons" as a separate course, it also acknowledged that the materials could also be incorporated into existing courses that dealt with topics such as history and civics. ${ }^{23}$

However, when it came to specific materials or courses on issues of food conservation developed by the Food Administration for America's public schools, there was very little produced during the agency's first year of existence. As will be discussed later, much of the effort in this regard was geared towards the higher education setting. The agency acknowledged this apparent shortcoming, forming an advisory committee to explore the "public school problem." In March of 1918, responding to demands from school officials, the Food Administration announced plans to prepare a more elementary form of a course that had already been prepared and distributed to colleges and universities. The goal was to get the course materials out to schools by the end of the academic year, though there is no indication that this goal was ever accomplished. One of the few items known to be produced solely by the Food Administration specifically for high schools was the book entitled Food Guide for War Service. Described as a "simple, reliable statement of the food program of the government," the book was intended to be used as a text of instruction. Published by Charles Scribner's Sons in the fall of 1918, the book contained eight chapters, each exploring a specific food (such as wheat, meat, or sugar) as it related to the war effort. It approached the food problem and the government's proposed solution, from a number of different angles. For instance, it touched on the global dimensions of the wheat supply, as well as the social and nutritional value of wheat and other cereals. The book not only attempted to explain why

23 USFA Public Information Division, Press Release Number 284, October 2, 1917, Box 47, Folder 5, Hoover Institution; untitled pamphlet (partial), Washington, D.C.: Government Printing Office, 1917, Box 47, Folder 5. 
students were being asked to modify their food behavior but also presented sound advice on how it could best be accomplished. According to Olin Templin, the book was not only valuable as "a method of cooperation with the government in winning the war," its importance also rested in its "fundamental educational value." Although the plan was to supplement the book with a laboratory manual that could be used in cooking classes, there is no indication that this was ever realized.24

By the summer of 1918 a number of national education associations were also appealing for materials tailored specifically for elementary schools. In the wake of these requests, the Food Administration began the process of producing a text in a similar mold to the aforementioned Food Guide, but the book did not make it to press until the war was nearly over. Thus its overall message would be changed to fit the impending postwar climate. That does not mean, however, that the Food Administration completely neglected the elementary school. Whenever the government embarked on a specific food conservation campaign, the Food Administration distributed pamphlets containing suggested curriculum and activities to the nation's schools. For example, in March of 1918 , the agency launched a national campaign that promoted the use of potatoes as a viable substitute for wheat in the conservation effort. In the elementary schools, teachers were told to include the discussion of the potato in various subjects, such as history and science. Additionally, instructors were provided with outlines for specific lessons on potatoes, and the government encouraged schools to do such things as

24 Olin Templin to Principles of High Schools, March 12, 1918, USFA Records, Hoover Institution, Box 374, Folder 1; Templin to Public School Systems of the United States, July 6, 1918, USFA Records, Hoover Institution, Box 374, Folder 1; Templin to State School Superintendents, August 17, 1918, USFA Records, Hoover Institution, Box 374, Folder 1; Katharine Blunt, Frances L. Swain, and Florence Powdermaker, Food Guide for War Service (New York: Charles Scribner's Sons, 1918), iv-22. 
highlight the food in school lunches, provide students with approved potato recipes, hold "potato essay contests," and have local farmers come in and discuss the crop with pupils. The goal was to have children "go home enthusiastic about the potato situation; to arouse interest in the rest of the family," and thus make it more likely that they would agree to follow the Food Administrations directives. ${ }^{25}$

The government also sought to capture the minds of the nation's youth by producing various children's stories, plays, and fairy tales. Typically, these works centered on a specific issue or type of food. Once such tale centered on the adventures of Captain Sugar, who eagerly accepted his call to service in helping the Allies overseas. In his absence, the likes of the Maple Brothers, Miss Honey, and Mr. Corn (described as being "American to his very roots") stood in for Captain Sugar at home to help with the "sweetening business." There was also a play entitled "The Patriotic Potato" written by the Food Administration. In the play, the potato campaign had begun, and a young student named Tommy comes home from school expressing his dislike of potatoes and complaining about the assignment he was given to write a story about his least favorite food. After falling asleep, Tommy dreams that he is visited by General Potato. The general tells the child about the Potato Army of America, who is fighting for Uncle Sam against the Kaiser. He briefly recalls the history of the food, stressing that

\footnotetext{
25 The book, entitled Food Saving and Sharing, would largely reflect the new direction the USFA's message took as the war neared its conclusion. It will be discussed in more detail in the next chapter.; Olin Templin to School Systems of the United States, July 6, 1918, USFA Records, Hoover Institution, Box 374, Folder 1; USFA, "Outline for Potato Campaign," (Washington, DC: Government Printing Office, March, 1918), NYS College of Home Economics Records, Series IV, USFA Records, Cornell University Libraries, \#23/2/749, Box 17; USFA, "School Leaflet for a Potato Campaign," (Washington, DC: Government Printing Office, March, 1918), NYS College of Home Economics Records, Series IV, USFA Records, Cornell University Libraries, \#23/2/749, Box 17.
} 
the potato is an American food, not Irish as is commonly thought. He emphasizes the importance of the potato in determining the outcome of the war. "We are to take the place of honor on the home table," says the potato, "in order that wheat may go to the front." The General tells the boy that, by not liking potatoes and failing to buy into the campaign, he is a "slacker." To avoid this label, Tommy needed to eat potatoes and avoid foods containing wheat. General Potato then offers to help the boy write a story so good that "everyone will want to eat potatoes and help win the war." In response, Tommy enthusiastically proclaims his support for the campaign, declaring, "You can count on me to help you spud the Kaiser." Upon waking form his dream, Tommy begins writing furiously and tells his mom that, rather than toast, he wanted potatoes for breakfast. ${ }^{26}$

During the Potato Campaign, teachers were also encouraged to read potato stories such as the Food Administration-produced "The Little Brown Prince" to students. The story, presented in the form of a fairy tale, begins in America, "long before the arrival of any white man." The protagonist, a downcast potato, expresses his frustrations to the King of Vegetables. He laments that he is one of the homeliest members of the kingdom, and by spending most of his life under ground, he feels useless to the world. The King responds by assuring the potato that, despite the dullness of his current situation, in the future he will have a major role to play. "There will come a time," explains the King, "when you will be exalted above most of the members of my kingdom." He goes on to declare that the potato had been given eyes so that he could

26 Emily Burt, "The Friends of Captain Sugar," manuscript, USFA Division of Home Conservation, undated, USFA Records, Hoover Institution, Box 12, Folder 13; Claudia Fitzgerald, "The Patriotic Potato - A Dialog," unpublished script, undated, USFA Records, Hoover Institution, Box 9, Folder 6. 
look out for this "one great event." After presenting this hopeful prophecy, the story briefly follows the potato over the proceeding years, tracing the arrival of Europeans to America, and the journey of the potato to Europe. Frustration for the potato grows until the present day, when the story tells of a "man king" from Germany determined to conquer the world. The time had come for the potato, and he works to grow vigorously for the United States in order to help the Allies defeat the Germans. The story also takes a moment to explain to the audience that potatoes are nutritionally a viable substitute for wheat, even citing a scientific study that showed how a child could receive as much strength from a medium-sized potato as they could a slice of bread. In the wake of his triumph, the potato was crowned a prince of vegetables, taking its place alongside Prince Wheat and Prince Corn. The fairy tale ended with a direct appeal to the children of America:

Every boy and girl can help this wonderful country in which he or she lives drive back the cruel king and his soldiers and win the war by asking mother to put more potatoes on their planes and by eating less bread made form wheat. They should also ask mother to make bread and muffins from potatoes. ${ }^{27}$

Traditional fairy tales were also used in conjunction with cartoons produced by the Food Administration which aimed to drive home the message of patriotic conservation. Such materials were displayed in places such as the comic strip section of newspapers. In one example, entitled "Save Sugar, Children," a young girl is depicted dropping her money in a collection box labeled "For the Children in Belgium and

27 USFA, "School Leaflet for a Potato Campaign," (Washington, DC: Government Printing Office, March, 1918), NYS College of Home Economics Records, Series IV, USFA Records, Cornell University Libraries, \#23/2/749, Box 17; Marion Phelan, "The Crowning of the Little Brown Prince: A Food Fairy Tale for Children," manuscript, undated, USFA Records, Hoover Institution, Box 9, Folder 6. 
France." While conducting this act of charity she bids farewell until after the war to a visibly upset piece of taffy and box of bonbons. The cartoon includes the caption "A Penny here means a Bun 'Over There,"' and in order to explain this concept to children it relates it to the English fairy tale, "The Old Woman and Her Pig." In this story, a poor old woman, in an act of charity, gives a cat a saucer of milk, which unleashes a chain of events that result in the woman obtaining a pig at the market. Similarly, if American children choose to eat less sweets, fewer ships would be needed to transport sugar to the United States, and those ships could be used to send needed supplies to children in France and Belgium. "All because you little Americans said 'none today' to the lollipops and candy," concluded the passage, "and started 'white magic' that reached across the Atlantic Ocean!" Another cartoon with the title "An Heroic Sacrifice" depicted a boy, and his dog, standing in front of a sweet shop with his hand raised, swearing to abstain from eating ice cream and candy for the duration of the conflict. These cartoons show that the Food Administration was willing to go outside the classroom to try to reach even the youngest Americans with their message of food conservation. ${ }^{28}$

The agency also worked to foster cooperation between local institutions that dealt with children on a daily basis. One example was public schools and libraries. Food Administration officials believed the public library was more than just a reading room. According to the agency's Library Section head Edith Guerrier it was the "educational extension department of the schools of the United States." In September of 1918 the Food Administration announced a plan to have children more explicitly commit to

28 USFA, "Save Sugar, Children," cartoon clipping, undated, USFA Collection, Hoover Institution, Box 401, Folder 6; USFA, "An Heroic Sacrifice," cartoon clipping, undated, USFA Collection, Hoover Institution, Box 401, Folder 6. 
changing their food behaviors in order to follow the guidelines set forth by the government. Officials in Washington informed agents at the state level of the creation of a program to have public libraries work with local schools to have children sign their own pledge cards. "So far," claimed the Food Administration, "the children of this country have not gone on record for food conservation." The agency's Library Directors in each state were instructed to reach out to all public librarians in their state, and have them secure the signatures of the children from the schools in their respective districts. It was suggested that the librarians propose to the school principals that they tell teachers during the week of Thanksgiving to connect the tradition of the holiday with the current situation in which Americans were sharing their food with the freedom-fighting forces in Europe. The students would then be presented with pledge cards similar to the ones very likely presented to their mothers and grandmothers several months earlier. Children could be told that by signing the pledge they were putting on record their part in the "great army of children who contributed services to their little brothers and sisters so far away." The signed pledges were then to be returned to libraries, where they could be kept on file, or even put on display in the children's rooms. Much like the pledges and home cards presented to the nation's adult population, the children's cards could serve as a strong visual statement of their commitment to the program. ${ }^{29}$

While educational materials for primary and secondary schools were slow to emerge from the Food Administration's national headquarters in Washington, other entities worked from an early stage to fill the void. Both local government institutions

29 Edith Guerrier, "Program of Library Cooperation with Schools, 1918-1919," memo, undated, USFA Records, Hoover Institution, Box 49, Folder 12; USFA to State Library Directors, September 24, 1918, USFA Collection, Hoover Institution, Box 49, Folder 13. 
and private individuals produced information intended for use in public schools on the food problem and its solution. Although the federal government was not directly responsible for producing these materials, the messages presented fell in line with the overall message that the Food Administration had crafted. As 1917 came to a close, the Department of Education in Texas was requesting that its schools cooperate with the government in the effort to save food. In December, it announced the publication of a series of fifteen lessons on the topic of food conservation that would be provided to all schools in the state that offered home economics courses. In addition to covering the general topic of eliminating food waste, the lessons emphasized the use of substitutes for such staples as wheat, meats, and fats while also covering practical preservation methods such as canning and drying. Another example was a book entitled Food Problems: To Illustrate the Meaning of Food Waste and What May Be Accomplished by Economy and Intelligent Substitution. The book was written by A.N. Farmer, the superintendent of schools in Evanston, Illinois, who had spent six weeks with the Food Administration in Washington during the autumn of 1917. Once again, the influence of agency's philosophy was clearly present. Farmer saw his work as part of the Food Administration's campaign in education, to "teach the nation the essential facts" of the food problem and the role Americans needed to play in winning the war and preventing global starvation. Success in implementing the program also had the potential of encouraging long-term character development among pupils, promoting such habits as thrift, self-control, and the spirit of cooperation. The book itself was marketed as both a handbook for teachers and a textbook for students. Regarding the material for pupils, the focus was on word problems that required arithmetic to solve, their aim being to 
illustrate and force students to consider the factors that contributed to the "food problem." It is difficult to determine how widely such materials were utilized, but they do illustrate how the message of the Food Administration's education campaign extended beyond the federal government itself. 30

As much as the Food Administration appeared to drag its feet when it came to the nation's public primary and secondary schools, it was much more productive in its relationship with colleges and universities. The reason for this imbalance is not entirely clear, but the record does suggest a probable explanation. There is no question that Food Administration officials saw college students, especially those studying fields related to home economics or nutrition, as potential field agents, with expert knowledge, that could be used, either during breaks or after graduation, to help spread the government's message on food conservation. Thus, at least in the early stages of its existence, it made the decision to direct most of its energy and resources to institutions of higher education. In August of 1917 the Food Administration reached out to all postsecondary institutions in America to gauge their interest in aiding the government in their food control program. It announced that University of Wisconsin president Charles Van Hise had joined the Conservation Division with the main objective of organizing the food conservation program among the nation's colleges and universities. Even at this early stage the Food Administration had already begun work on three different projects to provide information to colleges and universities. While the details were vague, one

30 Texas Department of Education, The Texas Advisory Educational Committee on Home Economics, "Fifteen Lessons in Food Conservation," Bulletin No. 71, December 1, 1917; A.N. Farmer and Janet Rankin, Food Problems: To Illustrate the Meaning of Food Waste and What May Be Accomplished by Economy and Intelligent Substitution (New York: Ginn and Company, 1918), i-17. 
still gets a sense of the intent and eventual direction the agency wanted to take in spreading its message among college students. The first was a syllabus for a set of lectures on food conservation designed specifically for the general student population. The second project was a syllabus for a more specialized set of lectures for students in fields such as nutritional science or home economics. Finally, the Food Administration aimed to produce specialized, periodic bulletins that focused on the global aspects of the food problem. ${ }^{31}$

For the most part it appeared as if the nation's colleges and universities were eager to assist the agency in their campaign, as officials within the Food Administration mentioned the high level of demand for any and all materials that were available. By the autumn of 1917 the Food Administration had produced a two-part pamphlet that provided an outline for a course of lectures. Comprising five separate chapters or lessons, the lectures covered everything from the prewar state of conservation in the United States to a detailed description of the Food Administration itself. At this time Van Hise was also in discussion with administration officials about the preparation of a food conservation textbook that would be published by a private firm and could be used in appropriate college courses. Given that the majority of Food Administration propaganda directed at the general population was focused on the nation's housewives, it is not surprising that the females on college and university campuses received particular attention. At the start of 1918, Hoover, in a letter addressed to the nation's college and university presidents, expressed the need for well-informed college girls to help stimulate conservation throughout the country. The presidents were asked if their female

31 R.L. Wilbur to Nation's Colleges and Universities, August 10, 1917, USFA Records, Hoover Institution, Box 46, Folder 13. 
students were "receiving instruction insuring intelligent cooperation with the Food Administration." Hoover also inquired if the schools were currently offering courses that would enable graduating females to "be of special service," and concluded by asking whether the institutions would be receptive to guidance from the Food Administration to better achieve these goals. He assured the presidents that a specific plan of action would be sent to each institution within a few days. ${ }^{32}$

As indicated above, the Food Administration viewed the college campus not only as an important setting to shape the minds of all students regarding food control, it was also viewed as a potential source of experts on the topic that could help spread the message to the broader population. Enlightening the entire American population on the food situation was a "perfect task for the American college student" - obtaining knowledge to not only shape personal habits, but to lead others to do the same. Thus, female students studying various fields in the domestic sciences received particular attention. It was these women, according to Hoover, who were "being prepared to grapple with the problems concerned with food and the home." He thus reached out to all departments of home economics in the country. The situation was presented as a unique opportunity to serve the nation. Once again, military imagery was used to drive home this message. Just as college men had been so important in filling the military ranks to fight the "war of arms", college women were being asked to join the ranks in

32 R.L. Wilbur to Edgar Rickard, internal memo, November 19, 1917, USFA Records, Hoover Institution, Box 46, Folder 13; Charles Van Hise, "Conservation and Regulation in the United States During the World War," (Washington, DC: Government Printing Office, October 20, 1917 \& January 1, 1918), USFA Records, Hoover Institution, Box 46, Folder 14; Hoover to College Presidents, telegram, January 15, 1918, USFA Record, Hoover Institution, Box 47, Folder 5; Hoover to College Presidents, telegram, January 18, 1918, USFA Record, Hoover Institution, Box 47, Folder 5. 
fighting the "war of food." "This splendid army of specially trained young women," proclaimed Hoover, "is counted on by the Food Administration to give willing and effective service." The agency's head also emphasized the value of the students' educational background in helping solve the food problem and assisting the nation achieve its ultimate goal of victory. "Issues that demand the rarest talent and the highest scientific training," proclaimed Hoover, "merit their attention."33

By all indications, it appears as if the nation's colleges and universities were receptive to the idea of forging a relationship with the Food Administration.

Organizations like the Deans of Women of American Universities, Colleges, and Normal Schools offered their full cooperation and "complete loyalty" to Hoover. However, despite the progress made in securing the assistance of the nation's post-secondary institutions, by the start of 1918 there appeared to be growing frustration within the Food Administration that not enough had been done in the production and distribution of materials to college campuses. To date, only a small handful of pamphlets and a brief outline of three courses had been presented to the schools. The first course, entitled "Food and the War," was to last four weeks, covering such diverse topics as an overview of the Food Administration, the fuel value of food, and the fuel needs of the body. The second course, which was called "Fundamentals of Food and Nutrition in Relation to the War," was to explore government control of food and dietary values of specific foods over a three week period. The final course, "Use and Conservation of

33 Hoover to Departments of Home Economics in the Colleges and Universities, telegram, undated, USFA Records, Hoover Institution, Box 47, Folder 5; Hoover to Educational Institutions with Women Students, January 25, 1918, USFA Records, Hoover Institution, Box 47, Folder 9. 
Foods," was also set to last three weeks and covered such topics as rations and the science of cooking. ${ }^{34}$

In order to increase the efficiency and productivity of the relationship with the nation's colleges and universities, the Food Administration in March of 1918 announced the creation of the Collegiate Section within the agency. Its purpose was to "promote the cooperation of the institutions of higher education, and their students and graduates, in the work of the Food Administration." It was also noted that the Collegiate Section would be assisted by the Department of Agriculture and the Bureau of Education in accomplishing its objectives. The section was to be headed by Olin Templin, then working as a dean at Kansas University, and the rest of the staff was made up of a variety of scholars and professionals in various fields of home economics and the biological sciences. Much like the organization of the Administration itself, the Collegiate Section in the nation's capital was supported at the state and local level. In each state a chief of college service was to be chosen, while each college and university would have a director or liaison that served as a representative of the Food Administration on campus. At the time of its formation, the three courses prepared by the government had been refined and expanded to include detailed outlines for each lecture. The first course, consisting of sixteen lectures, was open to all college students, while the second and third courses were geared towards upperclassmen with backgrounds in appropriate fields such as chemistry and physiology. The final course consisted of sixtyfour laboratory hours, focusing on practical applications that would prepare students to

\footnotetext{
34 Anne Dudley Blitz to Hoover, February 27, 1918, USFA Collection, Hoover Institution, Box 47, Folder 9; Charles Van Hise to Hoover, January 31, 1918, USFA Collection, Hoover Institution, Box 47, Folder 9;
} 
assist in Food Administration public demonstrations. Additionally, a condensed course of ten lessons had been prepared to distribute to the nation's public schools. ${ }^{35}$

In order to provide additional legitimacy and credentials to those completing the specialized coursework and successfully passing the required exams, the Food Administration provided certificates to those students that completed these tasks. The goal, as indicated above, was to "prepare an army of exceptional young women, by intensive training, for such special service as may be needed by the Food Administration." These services, as suggested by the agency, included assisting in public demonstrations, assembling and leading study groups in their neighborhoods, spreading the message of the Food Administration to children through reading stories, and helping with local library exhibits. To encourage qualified female students to engage in such activities, the Food Administration took out advertisements in publications. In one example, an insert, presented in the form of an article, was entitled "College Girls Give Vacation Days to Uncle Sam." It presented the summer vacation, long perceived as a time for rest and relaxation, as an opportunity to engage in the intense work of helping the war effort. Reporting on the opportunities available to college women seeking to help, the article presented various images of girls engaging in activities such as tending fields, harvesting crops, and canning food. The piece declared that such efforts were the main reason American society had remained so strong despite the absence of so much of the nation's "manpower." It also claimed that their sacrifice was just as important as the soldiers fighting overseas. "These young women," wrote the

35 USFA, "Collegiate Section," pamphlet, (Washington, DC: Government Printing Office, March 1918), from USFA Collection, Hoover Institution, Box 47, Folder 5 
Food Administration, "have dedicated themselves to their country no less than the boys who are fighting over in France today."36

By the end of the academic year in 1918, it became clear to the Food Administration that college women were not the only students who needed to be reached on campus. In an address to males currently attending college, Hoover focused on the topic of service to country. Realizing that many of the young men he was speaking to were struggling with the decision to either stay in school or join the fight, Hoover recalled the successful work done by American college students who had volunteered for the campaign for Belgian relief, combining idealism and efficiency to successfully aid tens of thousands of war victims. He proclaimed that those currently attending college "face a special responsibility and duty," which did not necessarily include military service. According to the Food Administration head, responding to the call of duty did not necessarily mean leaving campus. Hoover considered the nation's college students as a "privileged class," who possessed "an expanded mind, an uplifted spirit, and an understanding of the real meaning of patriotism." Just as important to the outcome of the war was a "technically trained mind," and thus he encouraged underclassmen to stay in school. Even upperclassmen were urged to "proceed cautiously" if called upon, and told to attempt to enter fields in the military that best suited their academic training. ${ }^{37}$

\footnotetext{
36 Olin Templin to State Federal Food Administrators, March 13, 1918, USFA Collection, Hoover Institution, Box 374, Folder 1; Templin to Colleges Giving Food Administration Courses, April 15, 1918, Hoover Institution, Box 374, Folder 1; US Food Administration, "College Girls Give Vacation Days to Uncle Sam," 6/11/1918, news clipping, from USFA Collection, Hoover Institution, Box 401, Folder 6.

37 Herbert Hoover, "The College Student and the War," address, undated, USFA Records, Hoover Institution, Box 47, Folder 5.
} 
Not surprisingly, the Food Administration emphasized that one of the most important ways young men remaining at home could help in the war effort would be to follow its guidelines and help spread the message of conservation to the rest of the country. In May of 1918 the Food Administration distributed a flyer entitled "An Appeal to College" men and encouraged the nation's college and universities to give it "proper publicity." In explaining the motivation behind this new campaign, Olin Templin expressed the agency's desire to challenge the common perception that the food problem was primarily the concern of women. "Men also must throw their influence heavily into the campaign," declared Templin, "or disaster is inevitable." It is difficult not to recognize the irony of such statements, given that the Food Administration itself in its propaganda over the previous year had at least a small role to play in cultivating such a perception. Regardless, this attempt suggests that, after nearly a year of work in trying to shape the minds and behavior of the American people, the government realized it had to broaden its message to include women as well as men. The flyer itself contained a series of slogans that attempted to portray the duty of conserving food at home as having the same importance as the boys fighting "over there." "The battlefield is here! The battle is now," claimed the Food Administration. College men were encouraged to become more informed about the food situation, carefully follow government guidelines, and "be aggressive agents of the Food Administration wherever you go." Much like the propaganda geared towards women, appeals for college men to not only follow but 
spread the message of food conservation was presented as an opportunity to not only serve the nation but to also improve the quality of their own lives. ${ }^{38}$

As the summer of 1918 came to an end and schools were gearing up for the upcoming academic year, the Food Administration finally succeeded in the publication of proper text books for both elementary and college students. However, the college text offered very little in terms of new material on food conservation. Rather, Food and the War, was little more than an expanded and detailed presentation of the three courses that had previously been prepared by the Food Administration. In Part I, materials from the first two courses were compiled and edited by Katharine Blunt, a professor of food chemistry from the University of Chicago, while Part II, containing more practical applications of nutrition concepts in the preparation of food, was edited by home economics professor Elizabeth Sprague. In addition, the textbook contained copies of two messages from Herbert Hoover, as well as a forward by the agency's Collegiate Section leader Olin Templin. The book for younger students, Food Saving and Sharing, appears to have been released even later in 1918, when the outcome of the war seemed rather certain. The overall message of the book, one in which the primary motive for conserving food was for humanitarian purposes rather than achieving victory in war, reflected a fundamental shift in the overall strategy of Food Administration propaganda. Even as the conflict wound down in the autumn of 1918, and victory for the United States and its allies grew more certain, officials within the Food Administration

38 Herbert Hoover, "The College Student and the War," address, undated, USFA Records, Hoover Institution, Box 47, Folder 5; Olin Templin to Presidents of Colleges and Universities, May 2, 1918, USFA Collection, Hoover Institution, Box 374, Folder 1; USFA, “Appeal to College Men," pamphlet, (Washington, DC: Government Printing Office, May 1, 1918), USFA Collection, Hoover Institution, Box 374, Folder 1. 
realized that the need for America to send large amounts of food overseas would persist during the postwar period. Thus, the need for Americans to continue to conserve food still existed. For their message to still resonate, the Food Administration would have to change its strategy alter the language of its propaganda. The next chapter will focus on this transition, which did not involve a dramatic transformation, but rather an increased emphasis on the theme that had been present in its message from the beginning. 


\section{Chapter 4 - "Transitioning from a 'War Consciousness' to a 'World Consciousness"”}

In addition to cultivating a sense of national duty and intelligent efficiency, Food Administration propaganda also attempted to encourage food conservation among the American public by getting them to consider more intimately the global dimensions of the food problem. Americans were not only confronted with vivid militaristic and patriotic imagery and messaging to generate a sense of service and duty to their own country, they were also exposed to propaganda that sought to bring about a feeling of obligation and compassion towards the nations and people of America's European allies. Thus, the efficient conservation of food was not only presented as an important weapon in waging war, it was depicted as a humanitarian exercise. The dramatic state of the food crisis facing the people (especially the women and children) of England, France, and Italy were regularly part of Food Administration propaganda. Attempts were made to also highlight the fact that our allies were making their own sacrifices at the market and the table in order to convince the American public that they were worthy of our assistance.

Accomplishing this would mean that Americans in general would need to view both themselves and the country in a more global context. Given the social and political tensions that surrounded U.S. involvement in the war, the leadership of the Food Administration recognized that this would very likely not be an easy task. Hoover himself acknowledged the potential difficulty in getting Americans to view problems from beyond the confines of the nation's borders. He lamented early on that most Americans had trouble understanding the world food problem. For many, the crisis began and ended with the price they had to pay for things like bread and meat. Few gave much 
consideration to the plight of hungry civilians in England or France. "The popular view is too self-centered," Hoover said of the people in the United States. "It does not look across the sea." Thus, a major aspect of Food Administration propaganda was to at least in part encourage Americans to think more globally. Government officials such as Hoover believed that doing so would help Americans gain a greater appreciation of how what they chose to eat not only impacted the food situation of the Allied nations in Europe, but also how it could shape the outcome of the war itself. Additionally, placing the food problem in a global context can also be viewed as a way political leaders attempted to reorient American views towards the nation's role in postwar global affairs. ${ }^{1}$

This chapter will analyze the various ways in which the United States Food Administration, attempted to influence American food behavior during World War I. More specifically, it will explore the global dimensions of the propaganda produced by the U.S. Food Administration during the First World War. As part of its message, the government attempted to connect food conservation and substitution at home with the broader global struggle against German aggression. Not only did the Food Administration work closely with Allied food controllers and media outlets to portray the food situation in England, France and Italy as being extremely perilous, it also made sure the American public knew that the fruits of their sacrifice were going to a worthy recipient that was conscious and appreciative of American efforts. Rather than being a burden, the program created by the Food Administration offered the nation an opportunity display its strength and efficiency to the rest of the world. Such appeals not only reflected a belief amongst many within the political establishment that the United

\footnotetext{
${ }^{1}$ Herbert Hoover, "The College Student and the War," undated, United States Food Administration Records, Hoover Institution, Stanford University, Box 47, Folder 5.
} 
States played a key role in shaping the outcome of the war itself, Food Administration propaganda also expressed a belief that the nation had an important responsibility in the postwar world. The global dimensions of the food problem, and the accompanying proposed government guidelines, can be found lingering in the background of even the earliest examples of Food Administration propaganda. However, as the war began to wind down in the autumn of 1918, it emerged front and center as the prominent theme in conservation publicity. By then the goal, according to Hoover, was to create "an intelligent world conscience" among the American people. ${ }^{2}$

The transnational dimensions of both propaganda during the Great War and food relief have been the focus of recent works from historians and other scholars. In the nineteen sixties, Mancur Olson explored the role of food supplies in determining the outcomes of the conflicts fought by an industrialized Britain, from the Napoleonic Wars of the nineteenth century to the Second World War. Regarding the Great War, Olson set out to explain how Britain, which relied heavily on food imports even before the outbreak of war and took no significant measures to stockpile resources in the event of conflict, was able to avoid widespread starvation and achieve victory. Adding further irony to the issue, according to Olson, was that Germany, unlike Britain, had taken steps during the early twentieth century to avoid a wartime food shortage and yet that is exactly what befell them in the final months of the conflict. Olson largely credits the flexibility of Britain's political system, and the unity of its population, to generate the needed increase in domestic production and reduction of the overall consumption of food. This, combined with the eventual participation of the United States ultimately led to the victory

2 "Hoover Appeals to World Conscience," 12/2/1918, New York Times, p.1. 
experienced by Britain and its allies. In his study of the First World War, Avner Offer not only stresses the importance of food in determining the outcome of the conflict, he assesses the role agricultural products played in causing the war, as well as its influence in shaping the peace. The industrial Atlantic economy, which had grown and developed throughout the late-nineteenth and early-twentieth centuries, had created the economic and political bonds that tied western Europe, especially Britain, to the United States. While this relationship was based on American exports of various raw materials, the single most important commodity was food. As industrial societies became more reliant on outside entities to provide such necessities, the global trade of food became the most important factor in shaping international relations. ${ }^{3}$

Historians have also recently begun looking at the influence of factors such as nutritional science and humanitarianism on the development of international food policy over the last century. In his study of modern global hunger, James Vernon holds the common belief that the problem of food shortage, at least since the beginning of the industrial era, is one largely caused by inequalities of distribution and access.

Predominant attitudes towards, and attempts to solve, the problem, according to Vernon, have gone through three phases over the last two centuries. The first viewed the phenomenon of hunger as a part of God's master plan and thus not something that should be interfered with. In the second phase, hunger was seen as a symptom of moral failings of the individual, who had failed to learn the virtues of hard work. Finally, the "social" phase that emerged in the early twentieth century emphasized the social

\footnotetext{
${ }^{3}$ Mancur Olson, Jr., The Economics of Wartime Shortage: A History of British Food Supplies in the Napoleonic War and in World Wars I and II (Durham, NC: Duke University Press, 1963) 3-32, 73-116; Avner Offer, The First World War: An Agrarian Interpretation (New York: Oxford University Press, 1989) $1-18$.
} 
and institutional causes of hunger and recognized the responsibility of all humankind that those suffering from hunger were at least in part the victims of political and economic systems. By World War I, the growth of biological and social sciences had brought forth a greater understanding of nutrition and emphasized that the political process could develop and implement practical solutions to the problem of hunger. The First World War would not only accelerate this process on the domestic front with food control policies, but would also do the same on the international front with both wartime and postwar food relief efforts. ${ }^{4}$

In his study of wartime publicity, Stewart Ross argues that the decision of the United States to declare war on Germany was at least in part due to the efforts of British government propagandists. He details a publicity battle on U.S. soil between the British, who wanted the United States to join the fray, and the Germans, who were for a least a time committed to keeping America on the sidelines. Such scholarship shows how, even before the United States officially joined the conflict, there was a flow of propaganda materials across the Atlantic. Additionally, recent scholarship has emphasized how food came to play an important role in shaping modern American foreign relations. By defining the value of food on the basis of a scientific quality such as the calorie, the subjective, cultural character of food was pushed aside as it became an instrument of statecraft. Beginning with the First World War and Hoover's Food Administration, and continuing through the Cold War and even to this day, American food aid will be used as a key component of its foreign policy, especially as it relates to "less developed nations." More recently Helen Veit has looked at how modern food culture, and the work of the

\footnotetext{
4 James Vernon, Hunger: A Modern History (Cambridge, MA: Harvard University Press, 2007) 1-17, 81-117.
} 
Food Administration in particular, helped shape how Americans viewed themselves within broader global community. Viet calls the Food Administration the nation's "first foreign aid program," one that not only aimed to provide immediate relief to people suffering overseas, but one that also hoped that the greater awareness of the global food crisis would spark a fundamental change in the wasteful consumption of food at home. ${ }^{5}$

If the government wanted to present a single individual to represent this "intelligent world conscience," to serve as a model for ordinary Americans to follow, they needed to look no further than Hoover himself. Despite Hoover's attempts to keep himself as an individual out of the spotlight, his personal history and background received attention. Various American media outlets published profiles of the Food Administration leader, which largely portrayed him as both the prototypical patriotic American success story and a modern "citizen of the world." Hoover was described as a "generous soul" and called the "embodiment of the efficient American." His past career as a globe-trotting, problem-solving engineer in such far-off places as China, India, and Australia was emphasized, as well as his humanitarian actions during the early years of the war as the head of the Commission for Relief in Belgium. He was portrayed as a "young hero of today," a "captain of industry and a master of men." Hoover represented the modern man in its purist form, a social engineer with global sensibilities. However, despite possessing such talents and skills, the man himself was completely disinterested in personal wealth or glory. He was a modest man, a reflection of his

\footnotetext{
${ }^{5}$ Stewart Halsey Ross, Propaganda for War (McFarland \& Co.: Jefferson, NC, 1996) 2-15; Nick Cullather, "The Foreign Policy of the Calorie," The American Historical Review (2007) 112 (2): 337-364; Helen Zoe Veit, Modern Food, Moral Food: Self-Control, Science, and the Rise of Modern American Eating in the Early Twentieth Century (Chapel Hill: UNC Press, 2013) 58-76.
} 
humble origins in rural lowa. Rather than his own ego, Hoover's concerns were with others. These traits were the very ones that Americans were encouraged to adopt in their efforts to conserve food. "We like to think that he is truly American," noted one publication aimed at the nation's youth, "because his interests and sympathies are as broad as humanity, because all mankind is his business, because in deed and in truth he is 'a citizen of the world."'6

Even after the creation of the U.S. Food Administration and Americans' fears of excessively-high food prices were not fully realized, food control early on was not readily accepted by all Americans. In trying to analyze the problem from a social perspective, noted medical scholar Alonzo E. Taylor attempted to explain why food control was not producing intended results. For him, the problem had deep psychological roots. "In this country we have difficulty in the program of food conservation," wrote Taylor, "because our people have not yet attained sacrificial consciousness for the carrying on of the war."7 The goal, argues Taylor, is to get Americans to view every act of their lives as a positive military measure. "When we have reached that plane," concludes Taylor, "the whole problem of food control becomes simplified, because the motivation is there that makes it possible to carry through a repression applied to foods."

Thus, one of the U.S. Food Administration's earliest and most important goals was to help American's achieve Taylor's "sacrificial consciousness." This resulted in the

\footnotetext{
${ }^{6}$ M.R. Parkman, "Herbert C. Hoover: A Citizen of the World," St. Nicholas Magazine, May 1917, 594; "The Efficient American," The Bellman, Nov. 23, 1918, 25, 566.

${ }^{7}$ Alonzo E. Taylor, "International and National Food Control," Annals of the American Academy of Political and Social Science 78 (1918): 156.

8 Taylor, "Food Control," 156.
} 
careful crafting of propaganda that contained three very important messages: the Allies were facing a dramatic food crisis and needed America's aid to win the war, the Allies were worthy and appreciative of the assistance, and the food program gave the American public the opportunity to show to the rest of the world the power of a democratic society. Hoover used all of the tools at his disposal to get his message out, and he worked closely with government officials in England and France, as well as popular media outlets, in an attempt to get Americans to buy into the food program of the U.S. government.

Even before coming home to lead the Food Administration, Hoover presented to the American people a bleak picture of how the war had impacted the civilian population in Europe. In a National Geographic Magazine article entitled "Bind the Wounds of France," Hoover described the devastation and misery he witnessed up close in his work as the head of the Commission of Relief in Belgium. "We are the only group who know if their suffering," he wrote, "and who know of what confronts those people even after peace." He stressed how desperately the regions of Belgium and northern France were in need of support and aid from the people of the United States. Not only were they in need, but they were worthy, as their suffering came from them fighting off further German expansion and upholding ideals Americans held dear. "France is sacrificing her manhood," proclaimed Hoover, "on a pyre devoted to liberty and a pyre devoted to our protection." From the start it was clear that the government wanted to generate a collective sense of sympathy towards the Allied populations. ${ }^{9}$

9 Herbert Hoover, "Bind the Wounds of France," National Geographic Magazine, 31 (May 1917) 439. 
Upon returning to the United States in April of 1917, Hoover delivered a message to the American people that expressed the critical nature of the food supply in Europe and the important role that food behavior in the U.S. would have on the outcome of the war. "The first and most important duty of the American people to their allies," declared the head of the U.S. Food Administration, "is to economize on foodstuffs." Failure to do so could jeopardize the entire Allied war effort. Hoover portrayed the food situation as serious and predicted that their supplies would not last beyond the month of September if the American people did not step up and dramatically alter their food habits by reducing their current rate of consumption. Although England, France and Italy were reducing their consumption "by drastic steps" it was still not enough. Hoover argued that the ultimate solution could only come from "the elimination of waste and actual and rigorous self-sacrifice on the part of the American people." Such actions were portrayed by Hoover as a display of patriotism, an opportunity for Americans who could not serve in the trenches to do their part in the war effort. ${ }^{10}$

At this early stage in American involvement in the war effort, Hoover was not only attempting to highlight the European food crisis to get the public to think more about food conservation, he was also trying to shape the political climate that would ultimately determine whether the agency he was tapped to head would even be granted legitimacy by Congress. To help craft the message that Hoover and the U.S. Food Administration wanted to present to political leaders and the American public, he took a number of steps to ensure that the news coming from Europe to the U.S. fell in line with what they wanted to say. One way to do this was to get the American papers to emphasize the

\footnotetext{
${ }^{10}$ New York Times, April 22, 1917; New York Times, May 20, 1917.
} 
poor food conditions in the Allied nations in order to convince the public that their actions were needed. In April of 1917 Sir William Goode, a British official, contacted Hoover to let him know that all American news correspondents in London had been contacted and were "no only glad to do everything to co-operate but really are extremely anxious for stuff." He stated that he had provided the AP and the United Press with various statements by members of Parliament on the food situation and was the one that arranged the aforementioned Kennedy Jones interview with the New York Tribune. At the time Goode also indicated that he was making additional arrangements to provide Daily Mail stories for various American newspapers. One month later Goode contacted Hoover again and indicated that the U.S. Food Administration had planned to use a "publicity man" to syndicate articles by well-known authors on food conditions in England. ${ }^{11}$

As the spring turned into summer, the future of the Lever Bill was still up in the air, and Hoover felt the need to do what he could to get momentum on the side of its passage. Writing to Lord Northcliffe of the British High Commission, Hoover stressed the importance of maintaining an image of England as suffering from food anxiety. He also expressed his dismay over recent comments by Northcliffe in which he stated that England had actually solved the food problem and suggested that he work quickly to "straighten out this impression." Northcliffe needed to insist that England was practically dependent on North America for her bread, and doing so "would be of extreme value to us in the work we are trying to do." Hoover responded to Goode's efforts by showing

\footnotetext{
11 Letter, Sir William Goode to Herbert Hoover, April 27, 1917, United States Food Administration Records, National Archives, Washington, D.C. (hereafter USFA Records), Record Group 4, Entry 442, Box 472; Goode to Hoover, May 9, 1917, USFA Records, Record Group 4, Entry 442, Box 472.
} 
appreciation of his work so far, but he wanted more information that portrayed the food crisis with the addition of "anxiety also from France." Hoover showed his desire to portray that the Allies were anxiously awaiting action from the U.S. and that if "we have no food control to give [the Allies] valid assurances they will be in complete despair."12

Responding to Hoover's request to get "some reflex action through the papers," William Ampoole of the British Ministry of Food met with a number of the editors of the major British newspapers, including the Daily Mail and the Telegraph. Ampoole reported to Hoover that the editors were very receptive and "only too glad to do anything both now and in the future." Ampoole also brings up a key point that will become a key part of the U.S. Food Administration's message to the American people once their food control program is enacted. Once the Lever Bill is passed, he argues that it will "be essential for us to show interest in, and gratitude for, its results in order to keep public opinion on your side, convinced that the sacrifices they are making...are essential to the Allies."13

In May, Goode supplied material for an article to the New York Times. It was an interview with R.W. Kindersley, Chairman of the War Savings Committee, whose objective was the promotion of voluntary rationing in England. The purpose was to "tell the American public something of the way in which he runs his highly successful campaign." Kindersley expressed his appreciation of the American sacrifice and proclaimed that their actions were helping a nation that was worthy of its charity. He spoke of his overwhelming confidence that the people of England would prove their

\footnotetext{
12 Hoover to Lord Northcliffe, June 18, 1917, USFA Records, Record Group 4, Entry 442, Box 472; Hoover to Goode, undated, USFA Records, Record Group 4, Entry 442, Box 472.

${ }^{13}$ W. Ampoole to Hoover, June, 15, 1917, USFA Records, Record Group 4, Entry 442, Box 472.
} 
worth "as it always has done before when in a tight corner, that it would willingly and cheerfully comply when it knew the real facts." He ended his interview by pointing out the cultural ties that linked the two nations in this struggle by stating, "the whole Englishspeaking world is now united." 14

Throughout the spring stories of the food emergency in Europe found their way to the pages of American newspapers. Goode sent the Chicago Daily News a copy of an article written by Mrs. C.S. Peel, the Director of the Women's Service in the Ministry of Food. Peel described the conditions in England that had made it nearly impossible to obtain food. Even those with the means to purchase nourishment were struggling. "You can go out today with money in your pocket," wrote Peel, "and fail to obtain a pound of sugar or a pound of potatoes. Later, who knows but that you may fail to obtain bread?" She ended her article with a particularly dire assessment. "The Germans have planned to starve us, and...their plan is working with considerable success." Later in the summer the British Ministry of Food "drew up" a statement for John Hodge, British Minister of Labour, that expressed his gratification towards the work of American labor leaders in trying to get the Lever Bill passed. Hodge went on to illustrate the importance of the food control legislation by discussing the need for U.S. assistance in the face of widespread food insecurity. "Every day's delay," warns Hodge, "now adds to our anxiety and uncertainty."15

\footnotetext{
14 Transcript, interview with R.W. Kindersley, May 12, 1917, USFA Records, Record Group 4, Entry 442, Box 472.

15 Transcript, article by C.S. Peel, May 15, 1917, USFA Records, Record Group 4, Entry 442, Box 472; Ampoole to Hoover, June 15, 1917, USFA Records, Record Group 4, Entry 443, Box 472.
} 
On the Fourth of July, the U.S. Food Administration issued a press release entitled "Food Economy in England." The release detailed the sacrifices of the Allies to show Americans, who were being asked to limit their consumption, that the English were worthy recipients of U.S. aid by doing their best to curb their intake as well. "Is John Bull," asks the article, "wearing his belt tighter than before the war?" The release went on to provide a number of examples to assure Americans that John Bull was indeed tightening his belt. It cited a report from a well-known American journalist who had just returned home from England and stated that he went hungry during his stay. He could not get enough to eat in any hotel or restaurant and detailed the English government's strict regulation of consumption and waste. For example, he reported that any household that was caught throwing even a piece of bread away was fined twenty shillings. The release also detailed the British Food Controller's voluntary rationing campaign within the home, which asked to limit bread consumption to four pounds a week per person. Using a practice similar to the Home Card campaign in the United States, participants were also asked to place a card in their window, and by all appearances the campaign was widely accepted throughout the country. In cases where the evidence appeared to challenge the purported level of sacrifice by the British to cut food consumption, American government officials were willing to "cook the books." While preparing graphic exhibits for upcoming state and country fairs that illustrated Allied food intake, estimates put actual British daily caloric intake at levels well above what was being recommended for the sake of the war. Wanting to give the 
intake a much lower figure, Hoover contacted the British embassy in Washington to gauge whether it would "be inadvisable to furnish such information."16

Once the Lever Bill was and signed into law in August of 1917, Hoover moved quickly to solidify the communication lines between the U.S. and the Allies. In a letter to Lord Rhondda, head of the British Ministry of Food, Hoover expressed his hope that through the U.S. Food Administration representative in the embassy in London, the two would be able to "work out an intimate co-operation." He also relayed his desire to continue working with William Goode, whose work Hoover found to be "of particular value...especially in the propaganda for conservation on this side, as the material he furnishes us is of daily use." In September Lord Rhondda called on Americans to send more food to the Allies. His message attempted to convince the U.S. public that their actions were important and greatly appreciated by the Allied populations. American homes, according to the Food Controller, "are helping to win the war just as surely as is the productions of munitions" and are "in a position to bring nearer the inevitable atonement for the brutal outrages in Belgium...the sinking of the Lusitania and other horrors." He went on to assure them that "there need be no fear that the sacrifices will be wasted here."17

One of the reasons there was such an emphasis on highlighting the dire conditions facing the people of the Allied nations was that there was a belief gaining momentum amongst Americans that the food crisis in Europe was not as serious as that

\footnotetext{
16 USFA, Press release, July 4, 1917, "Food Economy In England," USFA Records, Record Group 4, Entry 462, Box 490; Hoover to Lord Eustace Percy, July 26, 1917, Box 43, Folder 13, USFA Records, Hoover Institution.

17 Hoover to Lord Rhondda, October 2, 1917, USFA Records, Record Group 4, Entry 21, Box 7; New York Times, September 21, 1917.
} 
being portrayed by the media and government officials. By the end of 1917 Americans were increasingly reading reports, especially from travelers returning from England and France, that food was plentiful and often cheaper than it was at home. In October of 1917 the U.S. Food Administration released a series of articles by Fred Pitney, a "noted foreign correspondent," on the food situation in France. Not only did Pitney have access to official figures on the food supply from the French government, he had firsthand knowledge of the situation since he had lived in the country for a period of time. Pitney addresses the popular perception held by some Americans who had visited Paris that the dire food situation had been overblown. He argued that such individuals were likely only exposed to eating in hotels and restaurants where "one can always...order a meal and get it." In private homes, especially in the countryside, it was a different story, where French peasants "suffer in silence." The second article pointed out how and why the French Army received better food than civilians, as well the methods used to stretch out the rapidly disappearing food supplies. This "deplorable situation," according to the Food Administration's note to the editors "is vividly pointed out in a way to secure sympathy and understanding of Americans." The next month the U.S. government gave further details of the poor conditions facing the French people with the release of statistics on wheat and food production, which had decline by nearly half in the three years since the outbreak of war. ${ }^{18}$

\footnotetext{
18 USFA, "Clippings," New York Herald, December 6, 1917, Box 2, Folder 1, USFA Records, Hoover Institution; USFA, Press release, "The Food Situation in France," Article no. 1, Fred B. Pitney, October 20, 1917, USFA Records, Record Group 4, Entry 462, Box 490; USFA, Press release, "The Food Situation in France," Article no. 2, Fred B. Pitney, October 27, 1917, USFA Records, Record Group 4, Entry 462, Box 490; Press release, no. 441, November 9, 1917, USFA Records, Record Group 4, Entry 462, Box 490.
} 
Later that month the Food Administration began making arrangements for a group of American officials to travel through England and France for the purpose of obtaining "first-hand information as to the food situation...for use in propaganda throughout the country." The group, consisting of six men from various walks of life, including lawyers, and religious and business leaders, arrived in England on the fourth of December, made their way to France on the twelfth and other parts of western Europe throughout the rest of the month. They toured various operations that dealt with food, including municipal kitchens and farm training locations, visited agricultural regions and attended government-sponsored conferences and food control meetings. Upon their return at the end of the year, Hoover quickly began making arrangements with the State Department to set up speaking engagements throughout the United States. Officials who made the trip gave various details that attempted to show that American sacrifice was still needed. An official release from the Food Administration stressed that the group had worked hard to obtain a clear picture of the civilian experience and that the stories they would relay to audiences would be authentic. The words of the special commission would "not be in the form of official reports," declared the Food Administration, "but in the more interesting style of the lecturer who has an eye for the human interest element involved." One told of eating at a London hotel, "where the waiter gave you one thinly-cut slice of bread, a war bread composed of eighty percent whole-wheat flour and twenty percent substitute" while requests for extra sugar were refused. In France, farmland was destroyed and unsuitable for agriculture where "sections of that war stricken country are practically living under famine conditions." The speaking engagement ended with a plea to the audience to continue their conservation 
efforts. "Food will win the war," declared the speaker. "It is up to you to decide whether it is to be German food or our food which is the deciding factor."19

In addition to media outlets and public speaking tours, the U.S. Food Administration used other means to convince the American public that food conservation was needed in order to not only save a group of desperate (though worthy and grateful) allies but to also win the war and prove the righteousness of the American way on a global stage. Through the Administration's Education Division, the government produced a vast amount of propaganda, including posters, flyers, pamphlets and motion pictures, aimed at changing the dietary habits of Americans. Reflecting on the importance of visual media, George Creel, who headed the government's Committee on Public Information, stated, "I had the conviction that the poster must play a great part in the fight for public opinion. The printed word might not be read...but the billboard was something that caught even the most indifferent eye." One example of this form of propaganda as it related to the U.S. Food Administration depicted the "Heroic Women of France." It showed an image of French peasant women struggling in their attempts to produce food for their country. Underneath the image are quotes from the likes of Hoover and President Wilson, stressing the importance of American conservation to combat the horrible conditions overseas as well as the worthiness of the Allies in receiving this aid. At the bottom, the poster asks, "Are you doing your part?"20

\footnotetext{
19 F.C. Walcott to Edgar Rickard, November 19, 1917, State Department Records, Record Group 59, file no. 103.97/53a; USFA, Press Release No. 75, January 21, 1918, Box 51, Folder 20, USFA Records, Hoover Institution; Walcott to Hoover, December 23, 1917, State Department Records, Record Group 59, file no. 103.97/80; Hoover to Robert Lansing, December 22, 1917, State Department Records, Record Group 59, file no. 103.97/79; Hoover to Lansing, January 7, 1918, State Department Records, Record Group 59, file no. 103.97/87; Transcript, speech, undated, USFA Records, Record Group 4, Entry 442, Box 474

20 George Creel, How We Advertised America (1920; reprint, New York: Arno Press, 1972), 133.
} 
Film was also an important vehicle for presenting the European perspective to the American public. The U.S. Food Administration worked closely with Allied food control officials to produce a film that would touch on many of the major themes in the message to raise international awareness. To show that Britain was continuing to sacrifice even with American assistance and still needed more, a film on the British food situation was produced to be shown in American movie theaters. Included in the motion picture were scenes including a city park being plowed up by women driving Ford Motor tractors, the collection of boiled soup bones and used grease for the use in munitions production, and the use of cornmeal in the baking of "War Bread." The film ends with a cartoon image of a map of Britain placed within the borders of a United States map and the quote, "America can save a spare from her abundance." Government officials hoped that viewers would leave the theater feeling that their sacrifice was needed in order to win the war, and further, that the beneficiaries of the American effort to save food were worthy. ${ }^{21}$

As the war continued into 1918, Hoover and the U.S. Food Administration still felt the need to continue its close relationship with foreign food controllers to help craft its message aimed at manipulating the food behavior the American people. In January Hoover contacted a member of the British Ministry of Food informing him that the Food Administration was about to initiate a "more intensive conservation drive" in an attempt to save an additional seventy-five million bushels of wheat for export. Thus, he requested a cable from Lord Rhondda "expressing the imperative necessity of this provision." Three days later Rhondda obliged with a message stating that unless the

\footnotetext{
${ }^{21}$ Film transcript, "Suggestions for one reel film for U.S.A. on British Food Situation," undated, USFA Records, Entry 442, Box 472.
} 
U.S. sent required wheat to the Allies, he could not "take the responsibility of assuring our people that there will be enough to win the war." Rhondda then took the opportunity to appeal directly to the American people. While acknowledging the sacrifice already made, he declared that it "now lies with America to decide whether or not the Allies in Europe shall have enough bread to hold out." According to Rhondda, Americans were going to answer the call. "I am convinced," declared the British official, "that the American people, if they know the truth, will not hesitate to meet the emergency."22 One of Hoover's top officials within the Food Administration, Vernon Kellogg, worked diligently to insure that the American press was telling the story of struggle and sacrifice of Allied citizens overseas. In a series of internal memos within the organization, Kellogg provided ideas for press stories that highlighted the food crisis and the steps being taken by the people of France and England to ward off starvation. In England, Kellogg told of how the government, still relying on the voluntary cooperation of citizens to conserve food, had begun a system of rationing of animal feed. While animals such as horses and milk cows were given a ration, others such as pigs and beef cattle received no feed and thus had to rely on grass, roots, and straw. Such a restricted diet would lead to livestock that was drastically underweight, and as a result the English would be eating meat with little or no fat. Kellogg also focused on the recent laws passed by the British government in an attempt to curb food waste. He claimed that while the U.S. Food Administration was appealing to Americans to voluntarily conserve food, England went further to make the wasting of food an offense legally

\footnotetext{
22 Hoover to Sheldon, January 14, 1918, State Department Records, Record Group 59, file no. 103.97/94a; Sheldon to Hoover, January 17, 1918, State Department Record, Record Group 59, Food Administrator's File, no. 103.
} 
punishable by fine or imprisonment. Additionally, Kellogg worked to emphasize the plight of the French by detailing the recent implementation of bread rationing by the government. Given that bread composed nearly half of the French diet, this was a rather extreme measure. If Americans were made aware of this, Kellogg believed that Americans "may realize how far the French people are going in their efforts to restrict food consumption." The hope was that upon this realization they would decide to cut back on their own wheat intake. 23

While working on behalf of the Food Administration in Washington, Kellogg maintained his contacts in Europe from his time serving with Hoover in the Commission for Relief in Belgium. He made efforts to instruct American correspondents in France on how exactly to cover the social crisis for the audience back home. "Tell our people," wrote Kellogg, "that the French are meeting the serious food situation which they are now facing with characteristic bravery." He wanted reports that detailed how our allies were reducing food consumption in all ways while also struggling to increase their own domestic food production despite the manpower shortages. Finally, it was made clear that it was important to stress that American help was desperately needed to feed these people. The Food Administration also made efforts to increase its presence in France by appointing George McFadden, already serving as a representative of the War Trade Board, as a representative in Paris. He was tasked with assessing the food situation and reporting back to Food Administration offices in Washington. ${ }^{24}$

\footnotetext{
${ }^{23}$ Vernon Kellogg, undated, "Memorandum for Press Story from V.K.," Box 68, Folder 11, US Food Administration Records, Hoover Institution.

24 Vernon Kellogg to Lewis Strauss, internal memo, January 30, 1918, Box 5, Folder 19, USFA Records, Hoover Institution; Hoover to George McFadden, January 23, 1918, Box 39, Folder 9, USFA Records, Hoover Institution.
} 
Additionally, the Educational Division of the Food Administration attempted to work directly with the French Food Control agency to coordinate propaganda. Not only was the plan to craft a particular message coming out of France for an American audience, but it was also done with the hope of publicizing in France the work being done in the United States to bolster the morale of the French public. In March of 1918 Ben Allen, the head of the Food Administration's Educational Division, approved of a plan to provide both French government officials and journalists information that would allow them to publish "frequent, interesting articles detailing conservation efforts in the United States." In return, the contacts in France were asked to help provide information that would help in combatting the impression among Americans that "the French are not feeling any great food shortage." It was believed that such attitudes were hampering conservation efforts in the United States. By May of 1918 the Food Administration was sending a number of copies of various types of propaganda, including posters, bulletins, articles, and other "interesting documents" to the U.S. embassy in Paris. In return, the French government had pledged to supply the Food Administration with publicity materials on the food crisis there to be used in propaganda in America. Throughout the spring of 1918 officials in France working on behalf of the Food Administration worked to encourage cooperation between the U.S. and France through both media and governmental channels. ${ }^{25}$

In addition to coordinating propaganda and media relations to shape the attitudes of its people, the United States Food Administration also worked in a more public

\footnotetext{
25 Leonard Hatch to Herbert Hoover, June 13, 1918, Box 49, Folder 6, USFA Records, Hoover Institution; Hatch to Ben Allen, March 4, 1918, Box 49, Folder 6, USFA Records, Hoover Institution; Allen to Barton Blake, March 25, 1918, Box 49, Folder 6, USFA Records, Hoover Institution.
} 
capacity to cooperate in the logistics and policies of food relief with its counterparts in England, France, and Italy. This began as soon as Hoover was tapped by the president to lead the proposed food control agency. In April 1917 while still in Europe, Hoover began studying Allied food conditions and encouraging cooperation between the nations in both the logistics of shipping food supplies and the process of propaganda creation. Hoover was very conscious even at this early stage of the importance that the appearance of cooperation amongst the Allies would have on the public mindset. During these meetings he expressed the need to "organize publicity upon [the] needs of importing Allies with [the] view to stimulating effort from the exporting Allies." In England, Hoover met with the food control officials of the Allied nations and made a number of proposals for how the countries should work together to achieve their goals. He stressed the importance of cooperation, and for him the first step towards reaching that goal involved the creation of an international board that coordinated purchases and the shipment of goods from the United States. The ultimate goal in this regard was to try and prevent the various Allied nations from bidding against each other and driving up prices in America. 26

While this idea of cooperation had existed from the beginning, the formal machinery to ensure this process failed to materialized throughout the spring and summer of 1917. By the end of August, Hoover had grown frustrated with the situation, and he contacted the British War Office in London directly to demand the Allies create a common policy. Hoover threatened to embargo all American food exports if it did not

\footnotetext{
26 Telegram, Lansing to Page, April 12, 1917, Textual Records from the Department of State, National Archives, College Park, MD (hereafter State Department Records), Record Group 59, file No. 811.50; telegram, Page to Lansing, April 16, 1917, State Department Records, file no. 811.50/3; telegram, Page to Lansing, 04/19/1917, State Department Records, file no. 811.50/5
} 
happen soon. "We simply cannot have our whole consuming population demoralized," declared the Food Administration head, "and hate against the allies inflamed by this made competition between themselves." Within a month, British Food Controller Lord Rhondda had announced the formation of the Inter-Allied Food Council. The Council consisted of separate agencies tasked with securing imports of specific foodstuffs, such as wheat or fats. It contained representatives from Britain, France, and Italy, and each nation employed a full-time executive to oversee the coordination of the purchase and importation of foodstuffs from the United States. ${ }^{27}$

Even though the United States was able to push its allies in a direction that streamlined the flow of foodstuffs across the Atlantic, when it came to the issue of controlling the food consumption of its people, American relief experts and government officials largely came away unimpressed with their European counterparts. Making matters worse was the fact that projected grain harvests for the end of the year were going to fall well short of expectations. That, combined with continued difficulties in overseas transport caused by German submarine warfare made it more important than ever that America's European allies cut back on their grain consumption. One point of contention was the apparent lack of participation from the scientific community in shaping food control policy. Dr. Margaret Wilson, a Scottish immigrant working as a physiology professor at New York's Hunter College, came away from a trip to England thoroughly unimpressed with how the food crisis was being handled. She noted that

\footnotetext{
27 Offner, The First World War, 378; Telegram, Hoover to London War Office, August 24, 1917, Box 43, Folder 14, USFA Records, Hoover Institution; "Great Food Pool to Help Win War," September 21, 1917, New York Times, p. 1; Alonzo Taylor, "Report of Representative of the United States Food Administration as a Member of the House Mission to Europe, November and December, 1917," undated, Box 1, Folder 4, USFA Records, Hoover Institution.
} 
scientific experts were out of touch with the public, and that as a result, "much ignorance and crudeness" was pervasive amongst the British public. As 1917 came to an end Food Administration officials were still lamenting the fact that the food control policies of the Allied nations had not "received the advantage of a clear-cut scientific formulation of the problem." 28

The lack of influence from scientific experts was just part of a more generalized critical assessment in which American officials concluded that the control of food consumption by its citizens was handled differently by the Allies. In November and December of 1917 Alonzo Taylor, acting as a representative of the Food Administration, traveled to Europe as part of a larger contingent sponsored by the House of Representatives. Upon his return Taylor provided his analysis of the systems of food control as carried out by the Allies. In general, Taylor found that in England, France, and Italy very little was done by the government to control consumption. Shaping food behavior was not taken seriously by any of the nations. "The point of food administration from the standpoint of the consumer's conservation," reported Taylor, "was always far in the background." The matter was "left entirely to the unguided voluntary regime of the people." This was certainly different from the "voluntary regime" of the U.S. government which relied heavily on the Food Administration to generate a particular message. The lack of guidance from government propaganda was also noted by an American working for the Commission for Relief in Belgium. John Simpson, working in Paris to coordinate propaganda between the U.S. and France, noted that, when it came to food control, the

\footnotetext{
${ }^{28}$ Alonzo Taylor to Hoover, September 12, 1917, Box 43, Folder 14, USFA Records, Hoover Institution; Alonzo Taylor, "Report of Representative of the United States Food Administration as a Member of the House Mission to Europe, November and December, 1917," Box 1, Folder 4, USFA Records, Hoover Institution.
} 
French had fallen short. Government officials had failed to generate an appeal that resonated with the public. However, Simpson believed that could change if officials followed more closely the American model. The citizens of France that were at the time failing to buy in to food control measures "could be induced to do so if the problem was dramatized and pictured in the vivd terms of war and victory." Unfortunately, even after initial efforts had been made to secure the cooperation of the French government, American officials were lamenting the poor state of its ally's propaganda machinery, noting that it was in a "complete state of upheaval.". ${ }^{29}$

Taylor even noted a recent study of England's voluntary rationing system that had been conducted in London. The study found that the overall conservation of food by the British people was very slight if at all, and predicted that, despite the fears of potential class unrest and destruction of morale, mandatory rationing would soon be imposed by the government. U.S. officials also criticized that lack of cooperation amongst the European allies. "They do not trust each other," noted Taylor. Officials from one nation were not willing to initiate a more aggressive conservation program because they did not believe that their allies would follow suit. Despite the presence of entities such as the Inter-Allied Council, Taylor concluded that "coordination and leadership are lacking."30

\footnotetext{
${ }^{29}$ Alonzo Taylor, "Report of Representative of the United States Food Administration as a Member of the House Mission to Europe, November and December, 1917," Box 1, Folder 4, USFA Records, Hoover Institution; John Simpson to Ben Allen, May 14, 1918, Box 49, Folder 6, USFA Records, Hoover Institution; John Simpson to Leonard Hatch, June 20, 1918, Box 49, Folder 6, USFA Records, Hoover Institution.

${ }^{30}$ Alonzo Taylor, "Report of Representative of the United States Food Administration as a Member of the House Mission to Europe, November and December, 1917," Box 1, Folder 4, USFA Records, Hoover Institution.
} 
The United States quickly stepped in to fill that leadership void. During the joint meetings on food control that took place during the House trip to Europe, American officials took the lead. According to Taylor the United States was "viewed in an entirely different manner" by its European allies, meaning there was little suspicion or distrust. To solidify its leadership and ensure that it had a role in shaping the food control policies of its allies moving forward it set forth in creating the Inter-Allied Commission on Alimentation. This new body was consisted of eight experts in the field of nutrition, two from each of the major allied nations. Based in Paris, the Commission's main purpose was to make recommendations to the Allied governments in order to establish a level of consistency when it came to official food control measures. In addition to having a general feeling of leadership amongst the Allies, Taylor noted that another aspect of greater American involvement in coordinating food control recommendations was the additional advantage of it having a stronger scientific point of view. Experts on the new commission, declared Taylor, gave European scientists for the first time the "proper opportunity of impressing their viewpoint upon the food authorities of their own countries." 31

However, despite these developments, American officials still encountered obstacles when they attempted to exert more control over Allied policies. Facing increased domestic pressure over grain supplies and the fact that the Allied governments had done little to curb wheat consumption, Hoover sent American physiologists Russell Chittenden and Graham Lusk overseas in February of 1918 to

\footnotetext{
${ }^{31}$ Alonzo Taylor, "Report of Representative of the United States Food Administration as a Member of the House Mission to Europe, November and December, 1917," Box 1, Folder 4, USFA Records, Hoover Institution
} 
convince the Allies to cut their consumption of grain. They presented the latest scientific data obtained from experiments to officials from Britain, France, and Italy. They showed that humans could sustain health without negative consequence on a diet with restricted wheat intakes. Further, Chittenden and Lusk pointed out that the requested ration, a twenty-five percent reduction in current levels, was still higher than the current German ration, and there was no indication that the German people were struggling to maintain their health or support for the war effort. Despite these claims, the American representatives were met with resistance from the European food control officials. Citing the potential for social upheaval in response to a wheat ration, the Allies refused to implement the recommended restrictions. However, given that the U.S. ultimately controlled the amount of grains coming into Europe, the Commission agreed to a temporary policy in early 1918 that reduced the ration by ten percent. ${ }^{32}$

Greater U.S. engagement with the rest of the world would continue even after American military commitments ended. As it has been noted, throughout the war the impact of the food problem in Europe was linked to the potential of defeat at the hands of Germany. However, as the war wound down and the outcome of the conflict became clearer, the threat of a food crisis was increasingly associated with the potential of postwar internal political upheaval. This shift was also notable in the propaganda generated by the Food Administration. While Hoover's agency had always made a point to note the global nature of the food problem, the primary focus of the government's message to the American public shifted from one of military action to one of humanitarian relief and global political stability. In a National Geographic Magazine

32 Offner, The First World War, 379-381. 
article, Frederic Walcott of the Food Administration discussed not only how Germany had used food as a weapon of conquest, but also how widespread famine could potentially be a source of internal anarchy and upheaval. Pointing to recent events in eastern Europe, Walcott claimed that food shortages were a primary cause of the Russian Revolution. He went on to declare that the conditions that led to the "abject anarchy" in Russia were contagious and were a threat to spread west. Presenting what the Food Administration referred to as a "Hunger Map of Europe," as well as a number of charts and graphs, the article illustrated how the Allies faced dramatic shortages in various staple foods. According to Walcott, the only way to hold off a Bolshevik-style uprising in places like England and France was for Americans to reduce all forms of food consumption. ${ }^{33}$

As early as the summer of 1918 there began to emerge from the central offices of the Food Administration a desire to shift the overall nature of its messaging. In a note to the agency's Educational Directors, an official urged that they stop using the slogan "Food Will Win the War." Further, it was suggested that future propaganda avoid making "any statements by which it might be inferred that the service rendered by the Food Administration is on par with military service." "Our job," claimed one Food Administration official, "has changed from food helping 'to win the war,' to food helping 'to win the world." While it was noted that this change was in part due to the potential of better-than-expected crop yields in the upcoming harvest, as well as recent reports of increased casualties in the American military ranks, it also fell in line with an overall shift in the language of the propaganda that would increase as the war came to an end.

${ }^{33}$ Frederic Walcott, "Forerunners of Famine," National Geographic Magazine, 33 (April 1918): 336-348. 
Around the same time, Hoover noted in a conversation with President Wilson how successful the Food Administration had already been in conveying to the American public how their sacrifice has aided the Allies. In other words, the Food Administration had shown Americans how they "had morally and effectually a pooling of food stuffs with the allied peoples." To further enhance the idea that the Allies were "eating at a common table," Hoover expressed to the president his desire to propose the idea of a "universal bread." He believed that this would have a great unifying impact on the people living on either side of the Atlantic. ${ }^{34}$

As summer turned into fall in 1918, an Allied victory over the Central Powers appeared more and more within reach, and by October the Food Administration had arranged a publicity campaign that reflected this new reality. Despite victory, the need for food overseas would continue, and thus Americans were expected to maintain their adherence to conservation measures. Once again, the Four Minute Men were enlisted to present the government's food program for the upcoming year. In a letter to the public speaking organization, Hoover presented the Food Administration's talking points. The American public was to be informed that they had to continue saving food in order to "save civilization." Speakers were encouraged to emphasize how dependent on the U.S. the rest of the world had become over the course of the conflict, both our allies and the people that were about to be liberated. This additional responsibility was to once again be portrayed as an opportunity. "It is perhaps our greatest privilege," wrote Hoover, "that we are able to respond promptly and plentifully by simply exercising

\footnotetext{
${ }^{34}$ T.W. Ellis, "Memorandum to Educational Directors," June 13, 1918, Box 51, Folder 4, USFA Records, Hoover Institution; Ben Allen to State Library Directors, November 19, 1918, Box 49, Folder 14, USFA Records, Hoover Institution; Herbert Hoover to Woodrow Wilson, June 29, 1918, Box 5, Folder 19, USFA Records, Hoover Institution.
} 
forethought in our own provisioning and care in our consumption of food." The Four Minute Men were also told to "appeal to the intelligence" of the people. Hoover expressed continued confidence in the willingness of the average American to "assume individual responsibility in this matter," which to him was the greatest proof of the character and idealism of the nation. However, in the text of a sample speech provided to the speakers, there was an indication that Americans had yet to live up to Hoover's expectations. "In the year to come," asserted the government, "we must expect to share more equally with the allies and to shoulder a larger part of the burdens." The public was to be made to realize that now, more than ever, Americans were part of a global community which ate "at a common table."35

In November, with the end of the war now closer than ever, Hoover gave a speech that outlined how Food Administration policies would change given the "new world situation in food." While Hoover noted the end of specific guidelines such as use of wheat substitutes and the practice of meatless days, he added that there would be no change in stressing the "vital necessity of simple living, of economy in all consumption." Moving forward, the work of Hoover's agency was to take on a more global nature. He noted that, while some of the postwar food problems, such as those facing northern Russia, were beyond the capacity of the United States to solve, Americans had to continue saving food. "We must realize," noted Hoover, "that the specter of famine abroad now haunts the abundance of our table at home." And while the Food Administration was viewed as being only a wartime measure, Hoover claimed that he and his agency were the only ones equipped to continue the needed work of stimulating

\footnotetext{
354 Minute Men, "Food Program for 1919," Bulletin No. 40, October 10, 1918, Washington, DC: Government Printing Office, Box 10, Folder 19, USFA Records, Hoover Institution.
} 
and guiding Americans in the task of postwar food conservation. In addition to the moral aspects of continued conservation, Hoover stressed the political aspects of the postwar global food situation. Americans were told that failure to successfully feed war-torn Europe could have broader ramifications. "If we value our own safety and the social organization of the world, if we value the preservation of civilization itself," claimed Hoover, "we cannot sit idly by and see the growth of this cancer in the world's vitals; famine is the mother of anarchy." 36

Much like they had done during the autumn of 1917, the Food Administration organized a massive week-long pubic awareness campaign towards the end of 1918. Called "Food Conservation Week for World Relief," it was to be held in early December and would present this new phase of propaganda to the American public. Additionally, like earlier publicity efforts, the central office in Washington would provide the general guidelines, while the specific details would be handled at the the local level by Food Administration representatives. The federal agency began preliminary work for the campaign in mid-November, as Food Administration officials met with state assemblies and legislatures across the nation. Meetings were then held at the county level the following week, with Food Administration representatives meeting with prominent local business and political leaders to "conduct word of mouth propaganda." It is clear that the government was determined to assure that all people and institutions involved with the propaganda campaign were on the same page with regards to messaging. In order to reach as many Americans as possible with this new message, the Food

\footnotetext{
${ }^{36}$ Herbert Hoover, "Food Conservation for World Relief - Address by Herbert Hoover, November 12, 1918," November 1918, Washington, DC: Government Printing Office, Box 12, Folder 21, USFA Records, Hoover Institution.
} 
Administration would once again call on the nation's churches, libraries, and schools to engage with, and educate, the public on this new dimension of food conservation. ${ }^{37}$

In announcing the upcoming campaign, the Food Administration declared at the end of November in a press release that "every medium of reaching the American people" would be utilized to "bring before the public the change from a war basis to a world relief basis." Put another way, the goal of the government's propaganda shifted from cultivating a "war conscience" among the American public to developing a national "world conscience." Conserving food was once again presented as an opportunity for the United States, one whereby the true spirit of American democracy could be witnessed by the entire world, including those recently released from "German oppression." This would also mean providing assistance to people with which the U.S. was just recently waging war upon. Hoover shared with the American public that he, along with most of the nation, had mixed feelings about this prospect. However, he also stressed that the objective was not to provide full and complete relief for the former enemy, but to provide just enough aide to help prevent social and political upheaval. Additionally, the Food Administration claimed that only by feeding the starving people of Europe and beyond would the United States be able to establish its ideals on a global scale. Now that Germany and its allies had been defeated, a new enemy presented itself. Americans now had to send food overseas to prevent social and political upheaval. It was predicted that ten million deaths over the next year could result from the food crisis. One newspaper editorial quoted a Food Administration official who had claimed that by December of 1918 nearly every child in Poland under the age of seven

\footnotetext{
37 "Final Report of the Sub-Committee on Propaganda for Food Conservation Week for World Relief," November 1918, Box 13, Folder 21, USFA Records, Hoover Institution.
} 
had died from a lack of proper nourishment. Hoover proclaimed that the whole of Europe could experience the same fate as czarist Russia. "The red scourge of revolution," asserted the Food Administration leader, "is bound to spread." Much like previous campaigns from Hoover's agency, the "Conservation Week for World Relief" was to consist of various meetings and assemblies across all levels of society, each either headed by or directed by representatives of the agency. ${ }^{38}$

During certain days of the week, specific social institutions were to be the focal point of government food conservation propaganda. On Sunday, the first of December, the nation's churches were to kick off the campaign by making food conservation the focal point of their services. Every church in America was to receive a special message from Herbert Hoover, which was to be read to the congregation and serve as a basis for discussion. Such interaction was to "be reinforced by fresh cables from Europe" describing the dire food situation facing the people of the war-torn regions. On Tuesday, the plan was to hold coordinated public meetings at the local level, to be led by a Food Administration county representative. Wednesday was "Women's Organization Day," in which local women's groups were to meet with government officials to discuss and promote further food conservation. Finally, the focus on Friday of Conservation Week was the nation's schools and libraries. ${ }^{39}$

\footnotetext{
38 USFA, "For Morning Papers of Friday, November 29, 1918," November 27, 1918, Press Release No. 1320, Box 13, Folder 22, USFA Records, Hoover Institution; editorial, "Famine, Mother of Anarchy, is Hoover Warning in Crisis," December 1, 1918, The Sunday Star (D.C.), clipping, Box 13, Folder 21, USFA Records, Hoover Institution.

39 "Final Report of the Sub-Committee on Propaganda for Food Conservation Week for World Relief," November 1918, Box 13, Folder 21, USFA Records, Hoover Institution; USFA, "For Morning Papers of Friday, November 29, 1918," November 27, 1918, Press Release No. 1320, Box 13, Folder 22, USFA Records, Hoover Institution.
} 
The Food Administration reached out to the nation's libraries with its new message of global relief as early as mid-November when it asked them to "use every means of publicity at their disposal to carry this message into American homes." Hoover himself reached out to the nation's librarians in a letter published nationwide in various library bulletins. He began by thanking the librarians for their work to date, but also stressed that, despite the looming ending of the war, the work continued. "Your carefully prepared exhibits," wrote Hoover, "have awakened many a thoughtless person to an intelligent interest in the part that food must play in winning the war." It was now up to libraries to help explain the postwar food needs of the world, and the essential role Americans would play in fulfilling those needs. Within a week the offices in D.C. began coordinating with state-level Library Directors. They were instructed to engage immediately with local libraries to ensure their cooperation with the upcoming campaign. On the day set aside for libraries during "Conservation Week for World Relief," each librarian was to gather staff and read to them Hoover's message. Local libraries were also assured that updated materials reflecting the new program, such as a poster that stated "Teach Us to Share," were being sent directly. The Food Administration also provided ten specific tips libraries could follow to help with the campaign while the specifics for the program of early December were still being worked out. These included giving prominent space to Food Administration materials already on hand and sponsoring talks on global food issues..$^{40}$

\footnotetext{
40 USFA Educational Division to the Editors of Library Bulletins, November 16, 1918, Box 49, Folder 14, USFA Records, Hoover Institution; Ben Allen to State Library Directors, November 19, 1918, Box 49, Folder 14, USFA Records, Hoover Institution; USFA, "Special Message to Libraries for Food Conservation Week," November 1918, DC: Government Printing Office, Box 49 Folder 14, USFA Records, Hoover Institution.
} 
Libraries were also encouraged to hold specialized "Story Hours" for children throughout the month of December and specifically during the Conservation Week for World Relief. A Christmas-themed story produced by the Food Administration was distributed to libraries to use for this purpose. The "Christmas Story" once again provides a brief overview of the entire conflict in western Europe, focusing on the plight of Belgium and its experience with German occupation. It described the origins of the Commission for Relief in Belgium, its mission, and leadership at the hands of Hoover. It then went over the origins of the Food Administration and briefly discussed its wartime program. The story concludes by emphasizing the continued need for food conservation after the war and ends with a message from Hoover himself directed at the children of America. The words reflect the continued desire of Food Administration officials to shape, even among the nation's youth, the thoughts and actions of its citizens. In this particular case, the moral aspects of food conservation are stressed:

It is It is a fine thing that even children can do their part in helping to save starving people and the best gift children can give this year is the promise that they will help by eating cheerfully the simple food their mothers give them and that they will not ask for care and paid and candy when babies across the sea have only hard, dry bread. By this pledge each little patriot will help the Food Administrator for America to save food for those who have no happy home, no quiet, pressures country and no food but that we save and send them. ${ }^{41}$

In addition to the nation's libraries, the country's schools were also once again aggressively targeted by the Food Administration as a setting that would be used to reach children with the updated message of food conservation. Government officials still regarded the task of getting Americans to conserve food after the war as "almost

\footnotetext{
${ }^{41}$ Ben Allen to USFA State Library Directors, November 27, 1918, Box 49, Folder 14, USFA Records, Hoover Institution.
} 
altogether an educational one." Olin Templin, the head of the Food Administration's School and College Section, noted in mid-November that the end of the war had come unexpectedly quickly and expressed a level of uncertainty with how things would proceed as far as work with the nation's schools regarding food conservation propaganda. While Templin expressed an appreciation for the need for continued conservation, the fact that the primary goal of creating a "war conscience" among the American people had given way to generating a "world conscience" was a source of frustration. Two of the five school books (one geared for colleges and the other for secondary schools) that had been developed by the Food Administration had already been produced and thus failed to reflect this change in messaging. A third, geared towards elementary school students and entitled Food Saving and Sharing, was about to be published, while the future of the two yet-unpublished books was up in the air, although it was clear that the Food Administration would have no part in their production. 42

Templin and the Food Administration appeared to do little more than send a few form letters to the nation's colleges and universities requesting their continued support for the government conservation program while stressing more the global humanitarian dimensions of the problem. However, when it came to American primary and secondary schools, they seemed to be much more engaged. Food Administration was able to modify the content of Food Saving and Sharing before it went to press to reflect the new outlook on the government's food conservation propaganda. A full-page copy of the the "Hunger Map of Europe" was placed at the front of the book, while a brief message from

\footnotetext{
42 Olin Templin to Members of the Advisory Council, November 18, 1918, Box 374, Folder 3, USFA Records, Hoover Institution.
} 
Herbert Hoover to the "Girls and Boys of America" was included in the forward. In this message the Food Administration head appeals directly to the nations youth to help "save the world from famine." Also in the forward, was a poem by Sarah Louise Arnold entitled "Grace at the Table." It included the following stanza:

As we gather to be fed

Nations plead for daily bread, -

Fighting son and anguished mother, Orphaned children, - all together

Pray to thee for daily bread.

At Thy common table, Father, Ask we all for daily bread.

Additionally, the last two chapters of the book, "What We Have Yet to Do" and "The Little Group of One," also stressed the new emphasis on food conservation as a global relief effort and on the concept of the United States leading the efforts to bring comfort and stability to the postwar world. ${ }^{43}$

By the end of November, the Food Administration had prepared a detailed program for the nation's schools to follow for their designated day during the Conservation Week of World Relief. Copies of the program were distributed to every public school system in the nation. It began with a message to teachers from Templin who warned that "victory may yet be turned into disaster if intelligence and good will do not intervene." Claiming that children have a special capacity to appreciate the global dimensions of the food crisis since "the world is soon to be theirs," Templin urged teachers to "embrace this opportunity of enlightening and enlisting the young people" they oversee. The program itself was referred to by the Food Administration as a

\footnotetext{
43 Olin Templin to Universities and Colleges, November 19, 1918, Folder 374, Box 3, USFA Records, Hoover Institution; U.S. Food Administration, Food Saving and Sharing: Telling How the Children of America May Help Save - from famine - Their Comrades in Allied Lands Across the Sea, (New York: Doubleday, Page, and Co., 1918), p. vii-viii, 91-99.
} 
"patriotic program," declaring that all students "should share his country's desire to establish and maintain Liberty and Peace throughout the world." The major slogan to be repeated in schools around the country was: "Fighting Famine Over There; Saving,

Sharing, Over Here." School officials were urged to organize a "bright, snappy program, lasting at least an hour," where students could "sing patriotic songs, salute the flag, and repeat slogans." They were told to present a short play that emphasized the concept of the "common table." In addition, posters illustrating the "Hunger Map of Europe" and the "Food Map of the World" were to be put on display in the halls and the classrooms.

Schools were also instructed to promote local foods with the day's lunch, as well as take the opportunity to incorporate the government's message into the normal curriculum.

For instance, the Food Administration suggested that social studies classes could focus on the economic and political dimensions of the postwar global food crisis, while biology classes might present nutrition facts. ${ }^{44}$

Finally, the government provided to all schools, "The Home Message From Uncle Sam," which was a pledge that all students were to sign and take home to their families. The text of the pledge were as follows:

You have been saying "Food Will Win the War." You planted, you saved, and you shared, until the war was won. And now is your work ended? No. A greater work yet remains to be done. Starving Europe must be fed. Millions of hungry women and children reach out their hands to you. Remember their fearful need. Keep on saving. Keep on sharing. Waste not one morsel of food. It is sacred. You love your country. You have proved it in war; prove it now in

\footnotetext{
44 USFA, "Program For Schools, Friday, December 6th, 1918, Food Conservation Week for World Relief," November 1918, Box 374, Folder 3, USFA Records, Hoover Institution.
} 
peace. America is pledged to fight Famine, and feed a starving world. Will you do your part? - A Messenger for Uncle Sam. ${ }^{45}$

Even after the week-long campaign had ended the Food Administration continued to stress the importance of creating a school curriculum that promoted the "study of food, food values, and the food problem of the future in general." It its Food Saving and Sharing text as a means to supplement such course work. It was clear that the government officials and experts who made up the Food Administration envisioned a future where the lessons of efficient conservation and intelligent consumption would continue to inform American food behaviors long after the immediate crisis was solved. "One of the most impressive of the lessons of the war," wrote one Food Administration official, "is the necessity of every one know more about food." 46

As 1918 came to an end, the government was still pressing the urgent need for continued food conservation amongst the American people. "The whole food program has been changed," noted one Food Administration official, "from a war basis to a humanitarian or relief basis." While the end of the conflict had opened up opportunities for other parts of the world, such as South America and the Far East, to step in and help with food relief, tens of millions of new people recently liberated needed to be fed. By this time Hoover, as well as the U.S. Food Administration offices, had been transferred to Europe to "study the actual needs" and deal more directly with the problem of food production and distribution in the war-torn areas. However, despite such rhetoric, it does not appear that the Food Administration engaged in any further propaganda campaigns

\footnotetext{
45 USFA, "Program For Schools, Friday, December 6th, 1918, Food Conservation Week for World Relief," November 1918, Box 374, Folder 3, USFA Records, Hoover Institution.

${ }^{46}$ Olin Templin to Educational Periodicals, December 19, 1918, Box 374, Folder 3, USFA Records, Hoover Institution.
} 
after the start of the new year. In December, a group of Administration officials expressed a fear that a public backlash against the agency would result from recent changes in messages about conservation. By that time specific instructions concerning the type and amounts of certain foods had been replaced by general appeals to cut back on all food consumption. Additionally, the government removed completely suggested restrictions on foodstuffs such as wheat and sugar, while updated home cards were planned but perpetually postponed until they ended up on the permanent back burner. All of these developments no doubt contributed to an overall lack of engagement from the public by the start of 1919 , and by this time the agency itself was in the process of being dismantled. The United States Food Administration ended the wartime controls on production and distribution immediately after the Armistice on November 11, 1918. As was noted above, the conservation program died down between November and December of that year, and the Food Administration was completely abolished by Executive Order 3320 on August 21, 1920. Although it had ceased to exist as an active institution, its influence on the way Americans thought about food, and its role in the world, would persist. A great deal of importance was placed upon conveying the international scope of the food problem in Food Administration propaganda. U.S. food control officials, with the careful cooperation of their Allied counterparts, attempted to show Americans that their food behaviors had global consequences. These actions not only changed the way people ate, but also 
signaled a significant change in the relationship between the people and their

government. 47

${ }^{47}$ Maxcy Dickson, The Food Front in World War I, (Washington, D.C.: American Council on Public Affairs, 1944), pp. 177-179; William Mullendore, History of the United States Food Administration, 1917-1919 (Palo Alto, CA: Stanford University Press, 1941), 34-36; Gertrude Lane, "Minutes, Meeting of the Conservation Coordination and Policy Board," Box 11, Folder 10, USFA Records, Hoover Institution. 


\section{Conclusion}

By the end of 1918, the presence of the U.S. Food Administration in America had all but disappeared. Reflecting this shift away from domestic food conservation measures, Hoover himself left for Europe on November 16th to focus his attention and energy on relief for the war-torn region. The domestic food conservation offices of the agency were dismantled throughout the month of December, while the other aspects of Food Administration responsibilities were abandoned via various actions from both the president and Congress throughout the first half of 1919. In July, Herbert Hoover officially resigned as head of the Food Administration, and at that point the wartime agency ceased to exist. ${ }^{1}$

Despite the conflicts that arose in the creation of the Food Administration, and the subsequent frustrations that officials encountered in their attempts to achieve one hundred percent buy-in from the American public, by most accounts the agency succeeded in achieving the stated goal of increasing food exports to the soldiers and citizens experiencing the Great War in Europe first-hand. A simple assessment of the general outcomes of the conflict suggests that American food control policy was a success. First, the United States and its allies defeated Germany, and while it might be difficult to assess the exact level of importance food played in the ultimate outcome, it certainly had a role. Secondly, the American government through the Food Administration was able to, at lest on some level, implement its program without any significant level of resistance or social unrest. This is particularly notable given the growing concern over food prices, and the actual episodes of protest, in the months

\footnotetext{
1 William Mullendore, History of the United States Food Administration, 1917-1919 (Stanford, CA: Stanford University Press, 1941), 36-41, 355.
} 
leading up to American involvement in the war. In 1920 Hoover, looking back at these accomplishments, asserted that "the Allies would have starved" if food exports had remained at their prewar levels. He confidently proclaimed that, in addition to the impact of America's military contribution, "the organization and expenditure of our food resources contributed no less to winning the war."2

In terms of specific outcomes reflected in the numbers of wartime food production and exports, the results also suggest that the Food Administration had a positive impact. In terms of the stimulation of production, the amount of harvested acreage in the United States by the end of the war compared to the year prior to American involvement increased by nearly thirty million. The three-year average of net exports of all food and animal feed for the United States in the years immediately preceding American involvement in the war was just over six million tons. That figure rose to over fifteen million in 1917 and then to over eighteen million in 1918. By 1918 over ninety-four percent of the two hundred and thirty million bushels of bread grains exported were shipped to the Allies. Hoover also claimed that the government's price controls were overall successful given both the prewar concerns over food prices and the inflationary pressures that commonly come with war. From the time the United States entered the war until the Food Administration was dissolved, retail prices for food increased approximately twenty-five percent. Further, Hoover claimed that there were no episodes of famine, either local or widespread, nor the presence of black markets. The head of the Food Administration was also keen to stress that the agency neither

\footnotetext{
2 Mullendore, History of the United States Food Administration, 313-335; Herbert Hoover, The Memoirs of Herbert Hoover: Volume 1, Years of Adventure, 1874-1920 (New York: The Macmillan Company, 1951), 240-275.
} 
abused its powers or misused public funds in carrying out its program. The Food Administration avoided "evil consequences to American life" and was never charged with malfeasance despite taking on unprecedented control over the nation's food supply and handling over seven billion dollars in transactions. Finally, through its activities in coordinating the production, distribution, and trade of staple foodstuffs, the Food Administration, rather than costing the American public money, actually returned a $\$ 50$ million profit to the government. In almost every measurable way, the Food Administration represented for Hoover the perfect example of how the power of government could be used to positively shape society. ${ }^{3}$

Upon completing his public service, Hoover returned to food distribution in the private sector by remaining in Europe to work for the American Relief Administration. While Hoover moved on, his legacy and that of the Food Administration were lasting. They can both be seen as a byproduct of Progressive Era thinking, in which a proactive federal government, reliant on the advice and direction of experts in areas such as science, engineering, home economics and advertising, worked to influence and change the habits of the American people by stressing such themes as patriotism, efficiency and good health. The overall success of the food conservation program no doubt confirmed Hoover's strong belief in the ability of an informed public to solve complex social problems through "voluntary cooperation." One can see how this experience would shape President Hoover's response to the economic crisis he would face in 1929. However, the complexity and scope of the Great Depression was much greater than the food crisis of World War I, and the reliance on "voluntary cooperation"

\footnotetext{
${ }^{3}$ Mullendore, History of the United States Food Administration, 350-355; Hoover, The Memoirs of Herbert Hoover: Volume 1, 240-275..
} 
to solve the economic catastrophe proved wholly inadequate. Armed with a wealth of information from these professionals, the Food Administration initiated a program during the war that involved close interaction with a number of private media outlets in order to covey their carefully crafted message to the American public. In addition, a great deal of importance was placed upon conveying the international scope of the food problem. U.S. food control officials, with the careful cooperation of their Allied counterparts, attempted to show Americans that their food behaviors had global consequences. These actions not only changed the way people ate, but also signaled a significant change in the relationship between the people and their government. ${ }^{4}$

The U.S. Food Administration during World War I laid the groundwork, and prepared the American public, for much more drastic mandatory rationing that was implemented by the U.S. government during the World War II. In her cultural study of wartime government food control during this second great global conflict of the twentieth century, Amy Bentley finds that the Office of Price Administration, utilizing much of the same rhetoric and imagery of patriotism and sacrifice that was used by the Food Administration, was able to implement a much more aggressive form of food control without any more resistance than appeared to exist during World War I. Of course, differences in overall public acceptance of American involvement in each of the wars (especially after the attach on Pearl Harbor in 1941) should be considered, but the influence of the Food Administration on public attitudes towards subsequent

\footnotetext{
${ }^{4}$ Hoover appears to have taken many of the lessons learned from his time at the USFA and applied them to his work for the ARA. For a look at how Hoover continued to use American food as a weapon, against both hunger and Bolshevism in postwar Russia see Bertrand Patenaude's The Big Show in Bololand: The American Relief Expedition to Soviet Russia in the Famine of 1921 (Palo Alto, CA: Stanford University Press, 2002).
} 
government control of consumption should also be appreciated. Even beyond wartime government involvement in shaping American food choices, the efforts of the U.S. Food Administration should also be looked at as a key factor in growing presence of government recommendations and policies (at all levels) aimed at guiding the dietary behaviors of the people. In her seminal study of the politics of food in modern American society, Marion Nestle examines how the government, in the name of informing the public on healthy eating habits, has made tools such as the nutritional food label and the Food Guide Pyramid commonplace in American food culture. The aims and motivations of such governmental actions can be traced directly back to the ideas that guided the messages generated by U.S. Food Administration propaganda during World War I. 5

Aspects about the Food Administration's propaganda that emphasized a more rational or scientific approach to eating have had an even broader impact in shaping modern American food culture. Modern American food culture is tightly linked to the epidemic of obesity present in society, as well as to its connection to associated health problems and diseases. The fact that the growth in chronic, dietary-related diseases has coincided with an increasingly deep and sophisticated understanding of the science behind food is something that journalist and American food culture critic Michael Pollan has called the "American Paradox." In other words, the more we worry about and study nutrition from a scientific perspective, the less healthy as a society we seem to become. Pollan contends that a major factor contributing to this phenomenon is what he and

\footnotetext{
${ }^{5}$ Amy Bentley, Eating for Victory: Food Rationing and the Politics of Domesticity (Urbana: University of Illinois Press, 1998), 13-33; Marion Nestle, Food Politics: How the Food Industry Influences Nutrition and Health (Berkeley: University of California Press, 2007), 2-50.
} 
other scholars term "nutritionism." Nutritionism describes an ideology that believes that the key to understanding food is its nutrients. Any cultural or traditional meaning for food is stripped in favor of this reductionist view. Thus, according to Pollan, the true value of food is microscopic and thus invisible to the average person. The result has been an increasing reliance on experts to tell people what to eat, and the messages that are sent out are often complex and contradictory. By having an emotional detachment from their food choices, people are often more prone to abandon common sense and make poor decisions. ${ }^{6}$

According to Pollan, the process that has made "nutritionism" the guiding ideology of modern American food culture has been driven by efforts from various social institutions over the course of the twentieth century, including the government, the scientific community, and the food and advertising industries. The convergence of these three entities can first be seen in American society all the way back in 1917 when the U.S. Government, under the guidance of President Wilson and Herbert Hoover, took on the task of shaping the way Americans ate during World War I. ${ }^{7}$

\footnotetext{
${ }^{6}$ Michael Pollan, In Defense of Food: An Eater's Manifesto (New York: Penguin Books, 2008) 17-82.

7 Pollan, In Defense of Food: An Eater's Manifesto, 17-82.
} 


\section{Bibliography}

\section{Primary Sources:}

\section{Archives and Manuscript Collections:}

Herbert Hoover Presidential Library, West Branch lowa: United States Food Administration Documents

Hoover Institution, Palo Alto, California: Food Administration Records; Vernon Kellogg Papers; Benjamin Allen Papers; Alonzo Taylor Papers

National Archives and Records Administration, College Park, MD: Records of the United States Food Administration

National Archives and Records Administration, College Park, MD: Textual Records from the Department of State

\section{Periodicals:}

Annals of the American Academy of Political and Social Science

The Atlantic Monthly

The Bellman

Current History Magazine, New York Times

Evening Journal

Forum

Good Housekeeping

Independent

Journal of Home Economics

Ladies' Home Journal

The Literary Digest

The Nation

National Conference of Social Work, Proceedings

National Geographic Magazine

New Republic

New York American

New York Herald

New York Times

Outlook

Philadelphia Inquirer

Science

Scientific American

St. Nicholas Magazine

Sunday Star

The Survey 
Washington Post

Wilkes-Barre Record

Women's Home Companion

Time

\section{Published Primary Sources:}

Creel, George, How We Advertised America. reprint, New York: Arno Press, 1972.

Dickson, Maxcy Robson, The Food Front During World War I. Washington, D.C.: American Council on Public Affairs, 1944.

Farmer, A.N. and Rankin, Janet, Food Problems: To Illustrate the Meaning of Food Waste and What May Be Accomplished by Economy and Intelligent Substitution. New York: Ginn and Company, 1918.

Hoover, Herbert, American Individualism. New York: Doubleday, Page \& Co., 1922.

Hoover, Herbert, The Memoirs of Herbert Hoover: Years of Adventure. New York: The Macmillan Company, 1951.

Routzahn, Mary Swain, "The Chicago Patriotic Food Show: A Brief Review of its Main Features," Department of Surveys and Exhibits, Russell Sage Foundation, April 1918.

Taylor, Alonzo E., "International and National Food Control," Annals of the American Academy of Political and Social Science 78, 1918.

U.S. Congress. Congressional Record. 65th Cong., 1st sess., 1917. Vol. 55.

U.S. Food Administration, Food Saving and Sharing: Telling How the Older Children of America May Help Save "from Famine" Their Comrades in Allied Lands Across the Sea. New York: Doubleday, Page \& Company, 1918.

\section{Secondary Sources:}

Theses, Dissertations, and Other Unpublished Research:

Dileanis, Leonard P., "Herbert Hoover's Use of Public Relations in the United States Food Administration," MA Thesis, University of Wisconsin, 1969.

du Plessis, Elizabeth Cafter, "Meatless Days and Sleepless Nights: Food, Agriculture and Environment in World War I America," PhD Dissertation, Indiana University, 2009.

Veit, Helen Elizabeth, "Victory Over Ourselves: American Food and Progressivism in the Era of the Great War," PhD Dissertation, Yale University, 2008.

\section{Articles and Books:}


Belasco, Warren and Scranton, Phillip, eds., Selling Taste in Consumer Societies. New York: Routledge, 2002.

Bentley, Amy, Eating for Victory: Food Rationing and the Politics of Domesticity. Urbana, IL: University of Illinois Press, 1998.

Bentley, Amy, ed., A Cultural History of Food, vol. 6. New York: Berg Press, 2012.

Brewer, Susan A., Why American Fights: Patriotism and War Propaganda from the Philippines to Iraq. New York: Oxford University Press, 2002.

Capozzola, Christopher, Uncle Sam Wants You: World War I and the Making of the Modern Citizen. New York: Oxford University Press, 2008.

Clements, Kendrick A., Hoover, Conservatism, and Consumerism: Engineering the Good Life. Lawrence, KS: University of Kansas Press, 2000.

Costigliola, Frank, Awkward Dominion: American Political, Economic and Cultural Relations with Europe, 1919-1933. Ithaca, NY: Cornell University Press, 1984.

Cuff, Robert D., "Herbert Hoover, The Ideology of Voluntarism and War Organization During the Great War," The Journal of American History September 1977.

Cullather, Nick, "The Foreign Policy of the Calorie," The American Historical Review April 2007.

Dallek, Robert, The American Style of Foreign Policy: Cultural Politics and Foreign Affairs. New York: Knopf, 1983.

Davis, Allen F, "Welfare, Reform and World War I," American Quarterly Autumn 1967.

Davis, Belinda J., Home Fires Burning: Food, Politics, and Everyday Life in World War I Berlin. Chapel Hill, NC: University of North Carolina Press, 2000.

Dawley, Alan, Changing the World: American Progressives in War and Revolution. Princeton, NJ: Princeton University Press, 2003.

Dawley, Alan, Struggle for Justice: Social Responsibility and the Liberal State. New York: Belknap, 2000.

Day, Harry G., "E. V. McCollum: 'Lamplighter' in Public and Professional Understanding of Nutrition," Agricultural History January 1980.

De Bauche, Leslie M., Reel Patriotism: The Movies and World War I. Madison, WI: University of Wisconsin Press, 1997.

Diner, Steven, A Very Different Age: Americans of the Progressive Era. New York, NY: Hill and Wang, 1998. 
Fitzgerald, Gerard J. and Gabriella M. Petrick, "In Good Taste: Rethinking American History with Our Palates," The Journal of American History September 2008.

Gross, Robert N., "'Lick a Stamp, Lick the Kaiser:' Sensing the Federal Government in Children's Lives During World War I," Journal of Social History No. 4, 2013.

Hall, Tom G, "Wilson and the Food Crisis: Agricultural Price Control during World War I," Agricultural History January 1973.

Hawley, Ellis W., The Great War and the Search for a Modern Order: A History of the American People and Their Institutions, 1917-1933. New York: St. Martin's Press, 1992.

Hoff-Wilson, Joan. Herbert Hoover: Forgotten Progressive. Boston: Little Brown, 1975.

Hoganson, Kristin L., Consumer's Imperium: The Global Production of American

Domesticity, 1865-1920. Chapel Hill, NC: University of North Carolina Press, 2007.

Janik, Erika, "Food Will Win the War: Food Conservation in World War I Wisconsin," Wisconsin Magazine of History 93: 16-27.

Kennedy, David M., Over Here; The First World War and American Society. New York: Oxford University Press, 1981.

Keith, Jeanette, Rich Man's War, Poor Man's Fight: Race, Class and Power in the Rural South During World War I. Chapel Hill, NC: University of North Carolina Press, 2004.

Kingsbury, Celia Malone, For Home and Country: World War I Propaganda on the Home Front. Lincoln, NE: University of Nebraska Press, 2010.

Leach, William, Land of Desire: Merchants, Power and the Rise of a New American Culture. New York: Vintage Books, 1993.

Levenstein, Harvey, Revolution at the Table: The Transformation of the American Diet. Berkeley, CA: University of California Press, 2003.

McGerr, Michael, A Fierce Discontent: The Rise and Fall of the Progressive Movement in America, 1870-1920. New York: Oxford University Press, 2005.

Messer-Kruse, Timothy, "The Crusade for Honest Weight: The Origins of an Overlooked Progressive Movement," Journal of Gilded Age and Progressive Era July 2006.

Mullendore, William C., History of the United States Food Administration: 1917-1919.

Palo Alto, CA: Stanford University Press, 1941.

Murphy, Elizabeth Anne, Initiative Help: U.S.-Czechoslovak Relations from Versailles to Munich. PhD Dissertation, Cornell University, 1999.

Nash, George H., "An American Epic: Herbert Hoover and Belgian Relief in World War I," Prologue Spring 1989. 
Nash, George H., The Life of Herbert Hoover: Master of Emergencies, 1917-1918. New York: W.W. Norton, 1996.

Nestle, Marion, Food Politics: How the Food Industry Influences Nutrition and Health. New York: Penguin Books, 2008.

Offer, Avner, The First World War: An Agrarian Interpretation. New York, Clarendon Press, 1989.

Olson, Mancur, The Economics of the Wartime Shortage: A History of British Food Supplies in the Napoleonic War and in World Wars I and II. Durham, NC: Duke University Press, 1963.

Patenaude, Bertrand, The Big Show in Bololand: The American Relief Expedition to Soviet Russia in the Famine of 1921. Palo Alto, CA: Stanford University Press, 2002.

Pollan, Michael, In Defense of Food: An Eater's Manifesto. New York: Penguin Books, 2008.

Pope, Daniel, "The Advertising Industry and World War I," The Public Historian Spring 1980.

Reuss, Carol, "The Ladies Home Journal and Hoover's Food Program", Journalism Quarterly Winter 1972.

Ross, Stewart Halsey, Propaganda for War. Jefferson, NC: McFarland \& Co., 1996.

Schaffer, Ronald, America in the Great War: The Rise of the War Welfare State. New York: Oxford University Press, 1991.

Storm, Clair, Making Catfish Bait out of Government Boys: The Fight Against Cattle Ticks and the Transformation of the Yeoman South. Athens, GA: University of Georgia Press, 2009.

Vernon, James, Hunger: A Modern History. Cambridge, MA: Harvard University Press, 2007.

Veit, Helen Zoe. Modern Food, Moral Food: Self-Control, Science, and the Rise of Modern American Eating in the Early Twentieth Century. Chapel Hill, NC: The University of North Carolina Press, 2013.

Wiebe, Robert, The Search for Order. New York: Hill and Wang, 1967.201

Zieger, Robert H., America's Great War: World War I and the American Experience. New York: Rowan and Littlefield, 2000. 